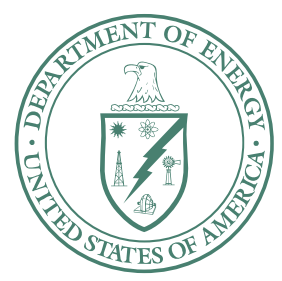

U.S. Department of Energy

Idaho Operations Office

\title{
ICDF Complex Remedial Action Work Plan
}

December 2006 
DOE/ID-10984

Revision 1

Project No. 23350

\section{ICDF Complex Remedial Action Work Plan}

December 2006

Prepared for the 


\begin{abstract}
This Remedial Action Work Plan provides the framework for operation of the Idaho Comprehensive Environmental Response, Compensation, and Liability Act (CERCLA) Disposal Facility Complex (ICDF). This facility includes (a) an engineered landfill that meets the substantive requirements of DOE Order 435.1, Resource Conservation and Recovery Act Subtitle C, Idaho Hazardous Waste Management Act, and Toxic Substances Control Act polychlorinated biphenyl landfill requirements; (b) centralized receiving, inspection, administration, storage/staging, and treatment facilities necessary for CERCLA investigationderived, remedial, and removal waste at the Idaho National Laboratory (INL) prior to final disposition in the disposal facility or shipment off-Site; and (c) an evaporation pond that has been designated as a corrective action management unit.
\end{abstract}

The ICDF Complex, including a buffer zone, will cover approximately 40 acres, with a landfill disposal capacity of approximately $510,000 \mathrm{yd}^{3}$. The ICDF Complex is designed and authorized to accept INL CERCLA-generated wastes, and includes the necessary subsystems and support facilities to provide a complete waste management system.

This Remedial Action Work Plan presents the operational approach and requirements for the various components that are part of the ICDF Complex. Summaries of the remedial action work elements are presented herein, with supporting information and documents provided as appendixes to this work plan that contain specific detail about the operation of the ICDF Complex. This document presents the planned operational process based upon an evaluation of the remedial action requirements set forth in the Operable Unit 3-13 Final Record of Decision. 


\section{CONTENTS}

ABSTRACT

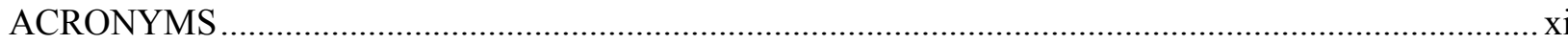

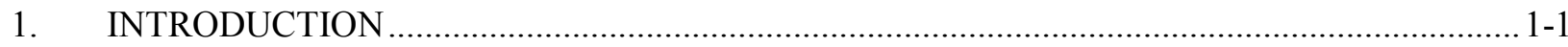

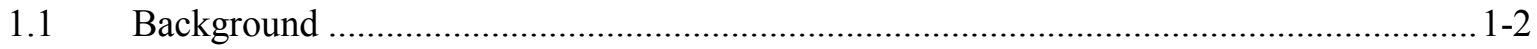

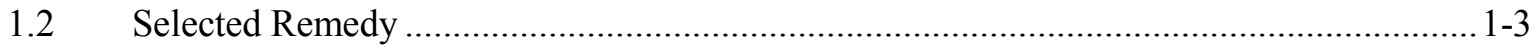

1.3 Relevant Changes to the OU 3-13 Remedial Design/Remedial Action Scope of Work .... 1-7

$1.4 \quad$ Remedial Action Work Plan Organization.............................................................. 1-7

1.4.1 Remedial Action Work Plan Organization................................................. 1-7

1.4.2 Remedial Action Work Plan Appendixes ................................................... 1-8

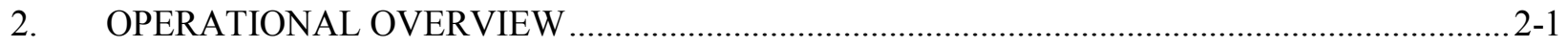

2.1 Waste Identification, Loading, and Acceptance ................................................... 2-1

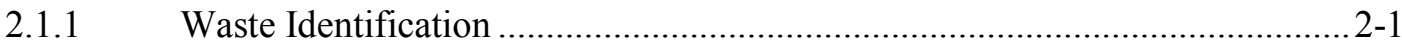

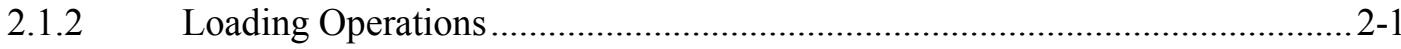

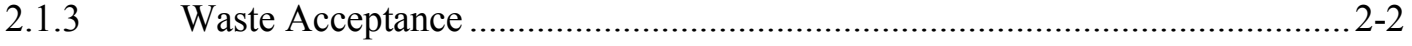

2.2 ICDF Complex Operational Scenarios ............................................................... 2-2

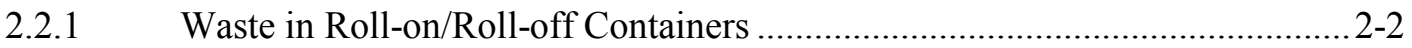

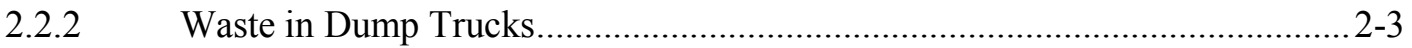

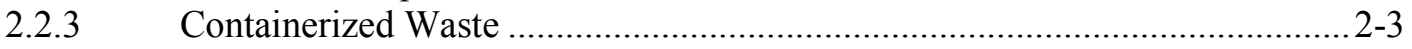

2.2.4 Waste Awaiting On-Site Disposal........................................................... 2-4

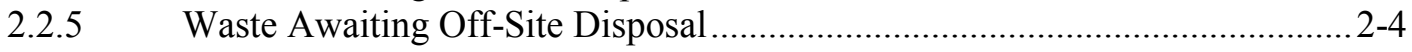

2.2.6 Aqueous Waste.......................................................................................

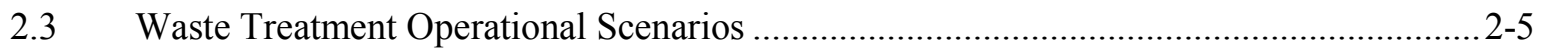

2.3.1 Waste Requiring Treatment to Meet Land Disposal Restrictions ................... 2-5

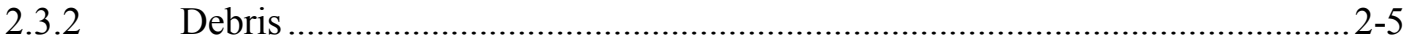

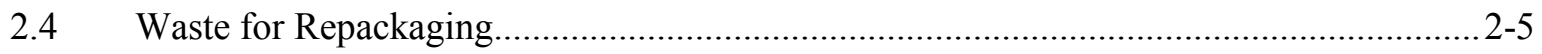

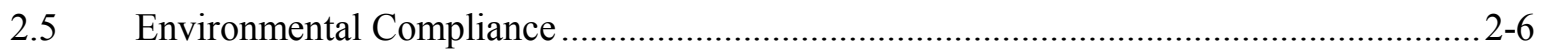


3. PROTECTIVENESS OF THE REMEDIAL ACTION ….....................................................

3.1 Waste Acceptance Criteria …............................................................................. 3-1

3.1.1 ICDF Complex Waste Acceptance Criteria ................................................. 3-1

3.1.2 ICDF Landfill Waste Acceptance Criteria ................................................... 3-2

3.1.3 ICDF Evaporation Pond Waste Acceptance Criteria ..................................... 3-2

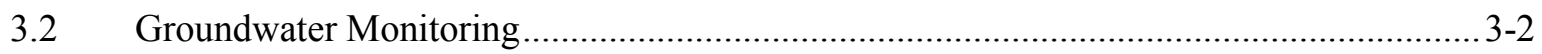

Final Landfill Cover ........................................................................................... $3-3$

3.4 Storm Water Pollution Prevention............................................................................ 3-4

4. REMEDIAL ACTION WORK ELEMENTS …........................................................... $4-1$

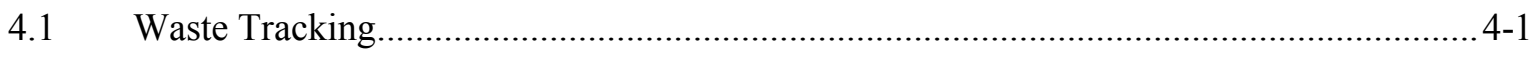

4.1.1 Identification of Waste to be Sent to ICDF Complex ....................................4-2

4.1.2 Waste Acceptance into the ICDF Complex .............................................. $4-3$

4.1.3 Waste Packaging and Shipment ........................................................... 4-3

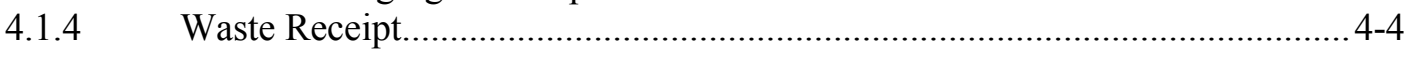

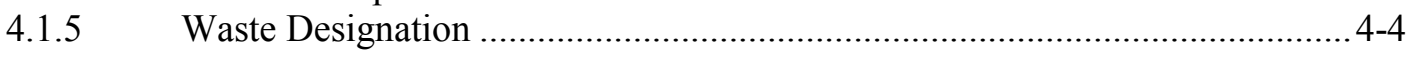

4.1.6 Inventory Tracking and Compliance Limits .......................................... 4-5

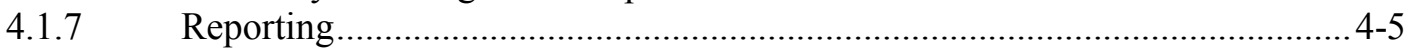

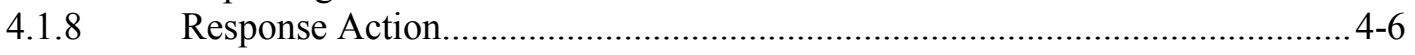

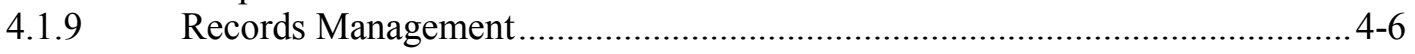

4.2 CERCLA Remediation Site Activities ...................................................................... 4-6

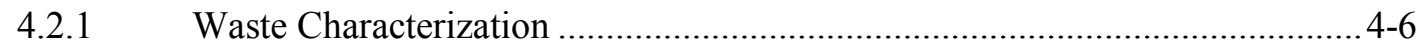

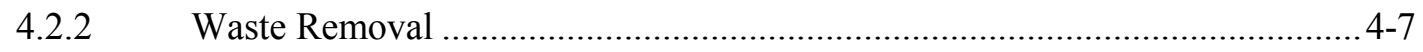

4.2.3 Waste Verification ................................................................................ $4-7$

4.2.4 Waste Packaging and Waste Area Group Staging ........................................ 4-7

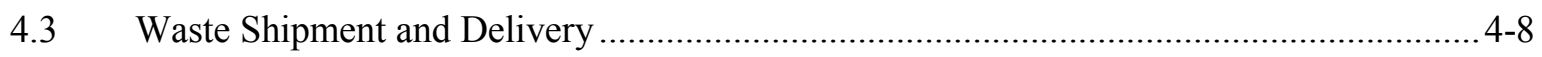

4.3.1 Waste Loading for Shipment............................................................. $4-8$

4.3.2 Waste Transport to Complex............................................................... $4-8$

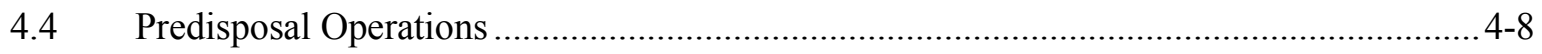

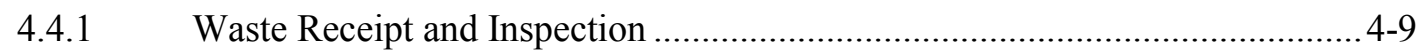

4.4.2 Waste Staging and Storage ................................................................. $4-9$

4.4.3 Waste Stabilization/Treatment ..................................................... 4-10

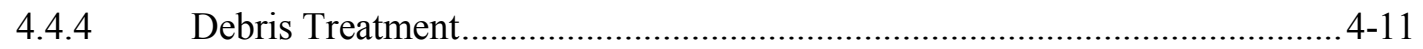

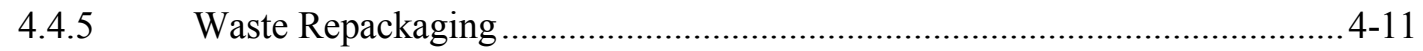

4.4.6 Decontamination Building .............................................................. 4 -11 


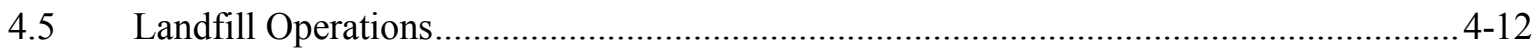

4.5.1 Waste Shuttle to Landfill..................................................................... $4-12$

4.5.2 Waste Off-Loading/Placement............................................................ 4-12

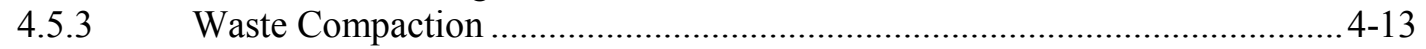

4.5.4 Dust Control ......................................................................... $4-13$

4.5.5 Radiological Survey Release from Landfill ......................................... $4-14$

4.6 Evaporation Pond Operations ............................................................................ $4-14$

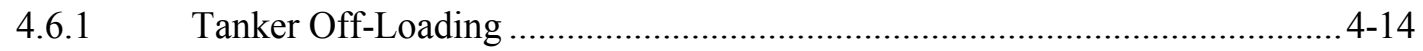

4.6.2 Landfill Leachate ............................................................................. $4-15$

4.6.3 Aqueous Waste Transfer from the Decontamination Building ..................... 4-15

4.6.4 Leak Detection Water.......................................................................... 4-16

4.6.5 Washdown and Freeboard ................................................................ 4 -16

4.6.6 Aqueous Waste from WAG 3 Wells ...................................................... $4-16$

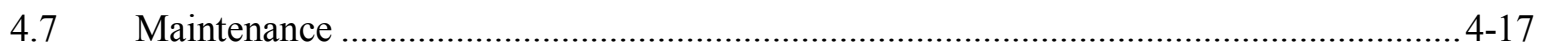

4.8 Environmental Compliance and Monitoring ...................................................... 4-18

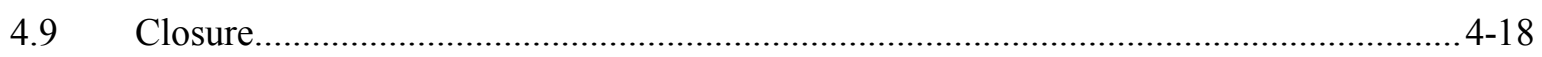

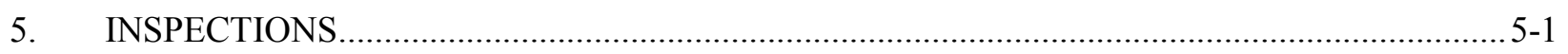

5.1 Post-Construction Agency Inspections................................................................ 5-1

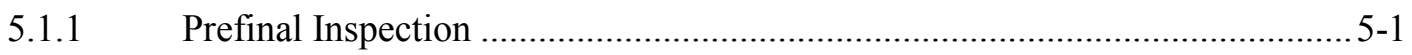

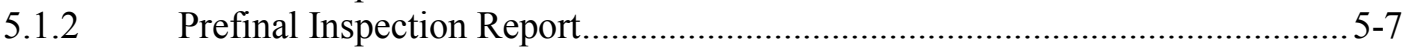

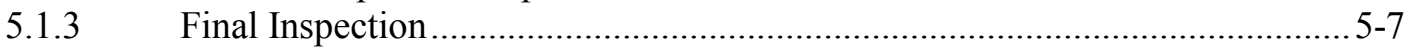

5.2 Environmental, Operation, and Maintenance Inspections .......................................... 5-8

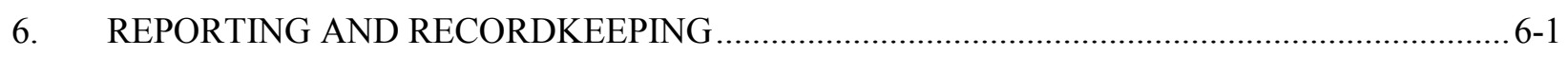

6.1 ICDF Complex Annual Reports ......................................................................... 6-1

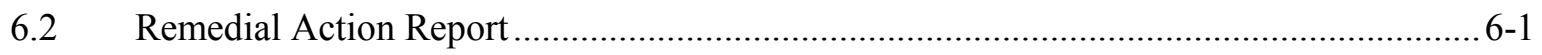

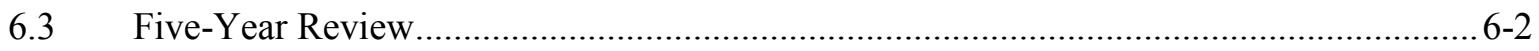

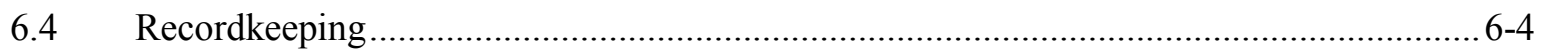

7. HEALTH AND SAFETY/EMERGENCY RESPONSE ....................................................... $7-1$

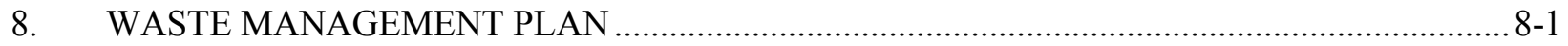

9. CLOSURE AND POSTCLOSURE REQUIREMENTS .....................................................

9.1 Staging, Storage, Sizing, and Treatment Facility Closure .......................................... 9-1

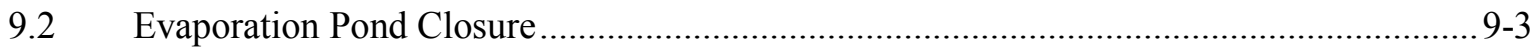




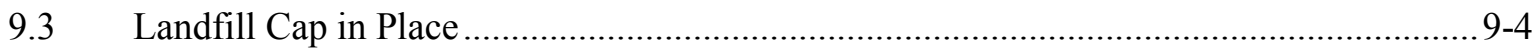

9.3.1 Final Cover Design .............................................................................. $9-4$

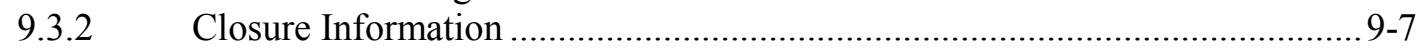

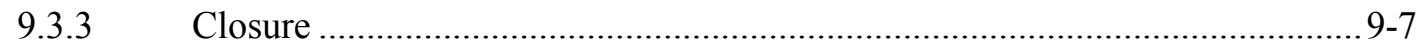

9.3.4 Post-Closure Maintenance.................................................................. $9-8$

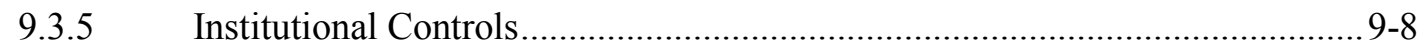

9.4 Closure Documentation/Certification....................................................................... 9

10. PROJECT SCHEDULE AND COST ESTIMATE ............................................................. 10-1

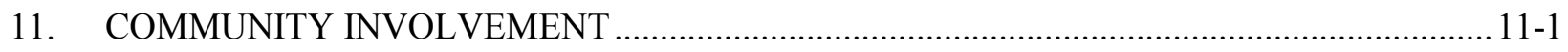

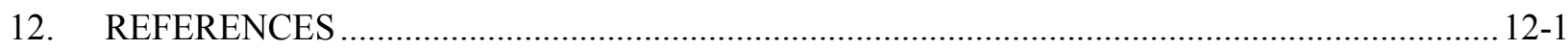

Appendix Volume 1 of 2-Idaho CERCLA Disposal Facility Complex Operations and Maintenance

Appendix A-ICDF Complex Operations and Maintenance Plan (DOE/ID-11000) ............................ A-1

Appendix Volume 2 of 2-Operational Informationand Project Management

Appendix B-ICDF Complex Waste Profile and Verification Sample Guidance

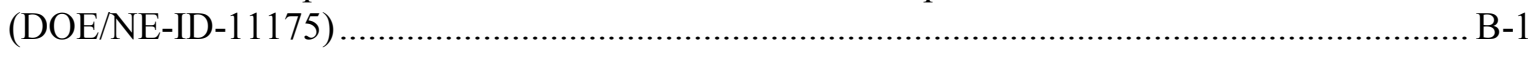

Appendix C—Waste Tracking Plan for the Idaho CERCLA Disposal Facility Complex (PLN-914) ..... C-1

Appendix D-(ICDF Complex Waste Verification Sampling and Analysis Plan [DOE/ID-10985]).

This document has been replaced by the document no contained in Appendix B ...................... D-1

Appendix E-INEEL CERCLA Disposal Facility Short-Term Risk Assessment (EDF-ER-327) .......... E-1

Appendix F-Health and Safety Plan for Idaho CERCLA Disposal Facility Operations

(INEEL/EXT-01-01318) ................................................................................................

Appendix G-ICDF Complex Operations Waste Management Plan (DOE/ID-10886) ....................... G-1

Appendix H-INEEL CERCLA Disposal Facility Groundwater Detection Monitoring Program:

Data Analysis Plan (DOE/ID-10998) ....................................................................................

Appendix I — Treatability Study Test Plan for Soil Stabilization (DOE/ID-10903) .................................

Appendix J-Sampling and Analysis Plan for SSSTF Waste Stabilization Operations, WAG 3,

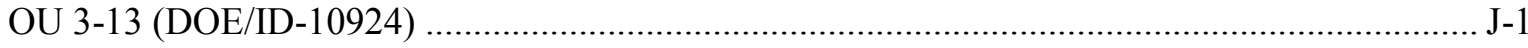

Appendix K-NESHAP Compliance Demonstration for the ICDF Complex (EDF-2236).................... K-1

Appendix L-IDAPA Air Compliance Demonstration for the ICDF Complex (EDF-2237) ................. L-1

Appendix M-ICDF Complex Operational and Monitoring Sampling and Analysis Plan

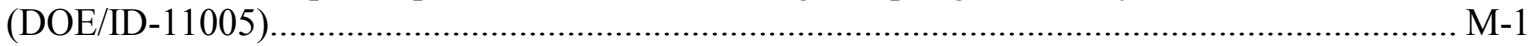




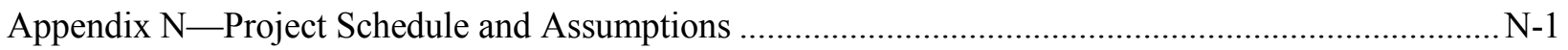

Appendix O_INEEL CERCLA Disposal Facility Complex On-Site Versus Off-Site Cost

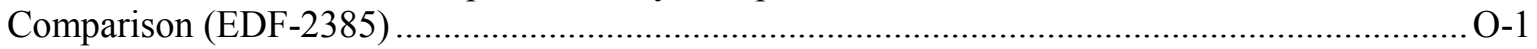

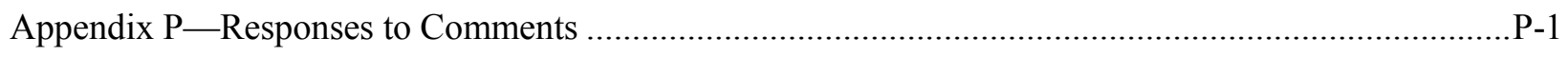

\section{FIGURES}

1-1. Map showing the location of INTEC within the Idaho National Laboratory ................................ 1-2

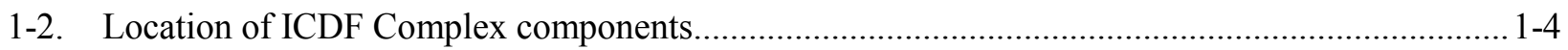

4-1. The ICDF Complex waste tracking process ..................................................................... $4-2$

6-1. Records management process for the ICDF Complex ............................................................ $6-4$

9-1. ICDF landfill final cover system sections and details .......................................................... 9-6

\section{TABLES}

4-1. Schedule for CERCLA project and ICDF Complex interaction ................................................ 4-3

5-1. Draft ICDF Complex prefinal inspection checklist .............................................................. 5-2

5-2. ICDF Complex routine operations and maintenance inspections.............................................5-8

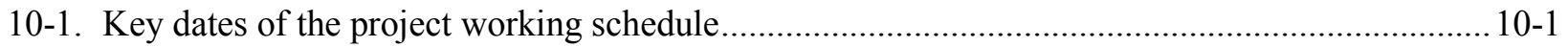




\section{ACRONYMS}

ALR action leakage rate

ARAR

$\mathrm{AR} / \mathrm{IR}$

$\mathrm{CAB}$

CAMU

CERCLA

CFR

DD\&D

DEQ

DOE

DOT

EDF

EDM/OIS

EDMS

EPA

FFA/CO

FS

FY

HASP

HAZWOPER

HDPE

HEPA

HVAC

HWMA

ICDF applicable or relevant and appropriate requirement

Administrative Record and Information Repository

Citizens Advisory Board

Corrective Action Management Unit

Comprehensive Environmental Response, Compensation and Liability Act

Code of Federal Regulations

deactivation, decontamination, and decommissioning

[Idaho] Department of Environmental Quality

Department of Energy

Department of Transportation

engineering design file

Electronic Document Management/Optical Imaging System

Electronic Document Management System

Environmental Protection Agency

Federal Facility Agreement and Consent Order

feasibility study

fiscal year

health and safety plan

Hazardous Waste Operations and Emergency Response

high-density polyethylene

high-efficiency particulate air

heating, ventilating, and air conditioning

Hazardous Waste Management Act

Idaho CERCLA Disposal Facility 


\begin{tabular}{|c|c|}
\hline IDAPA & Idaho Administrative Procedures Act \\
\hline INEEL & Idaho National Engineering and Environmental Laboratory \\
\hline INEL & Idaho National Engineering Laboratory \\
\hline INL & Idaho National Laboratory \\
\hline INTEC & Idaho Nuclear Technology and Engineering Center \\
\hline IWTS & Integrated Waste Tracking System \\
\hline LCRS & Leachate Collection Recovery System \\
\hline LDR & land disposal restriction \\
\hline LLW & low-level waste \\
\hline MEI & maximally exposed individual \\
\hline MLLW & mixed low-level waste \\
\hline NESHAP & National Emission Standards for Hazardous Air Pollutants \\
\hline O\&M & operation and maintenance \\
\hline OSHA & Occupational Safety and Health Administration \\
\hline OU & operable unit \\
\hline PCB & polychlorinated biphenyl \\
\hline PLDRS & Primary Leak Detection and Recovery System \\
\hline PPE & personal protective equipment \\
\hline RA & remedial action \\
\hline RadCon & Radiological Control \\
\hline RAWP & Remedial Action Work Plan \\
\hline RCRA & Resource Conservation and Recovery Act \\
\hline $\mathrm{RD} / \mathrm{CWP}$ & Remedial Design/Construction Work Plan \\
\hline $\mathrm{RD} / \mathrm{RA}$ & remedial design/remedial action \\
\hline RI & remedial investigation \\
\hline RI/BRA & remedial investigation/baseline risk assessment \\
\hline
\end{tabular}




$\begin{array}{ll}\text { RI/FS } & \text { remedial investigation/feasibility study } \\ \text { ROD } & \text { Record of Decision } \\ \text { SAP } & \text { Sampling and Analysis Plan } \\ \text { SOW } & \text { Scope of Work } \\ \text { SRPA } & \text { Snake River Plain Aquifer } \\ \text { SSA } & \text { Staging and Storage Annex } \\ \text { SSSTF } & \text { Staging, Storage, Sizing, and Treatment Facility } \\ \text { TFR } & \text { technical and functional requirements } \\ \text { TSCA } & \text { Toxic Substances Control Act } \\ \text { TSDF } & \text { Treatment, Storage, and Disposal Facility } \\ \text { WAC } & \text { Waste Acceptance Criteria } \\ \text { WAG } & \text { waste area group } \\ \text { WMP } & \text { Waste Management Plan } \\ \text { WTF } & \text { Waste Tracking Form }\end{array}$




\section{ICDF Complex Remedial Action Work Plan}

\section{INTRODUCTION}

In accordance with the Federal Facility Agreement and Consent Order for the Idaho National Engineering and Environmental Laboratory (FFA/CO) (DOE-ID 1991) between the U.S. Department of Energy (DOE), the U.S. Environmental Protection Agency (EPA), and the Idaho Department of Environmental Quality (DEQ) (hereinafter referred to collectively as the Agencies), the Department of Energy Idaho Operations Office (DOE Idaho) submits the Remedial Action Work Plan (RAWP) for the operation of the Idaho Comprehensive Environmental Response, Compensation, and Liability Act (CERCLA) Disposal Facility (ICDF) Complex at the Idaho Nuclear Technology and Engineering Center (INTEC). This RAWP has been prepared to be the basis for the implementation of the Final Record of Decision, Idaho Nuclear Technology and Engineering Center, Operable Unit 3-13 (ROD) (DOE-ID 1999) for the ICDF Complex. This ICDF Complex RAWP has been identified as a primary document under the FFA/CO, which outlines the review and revision protocol for this document.

The ICDF Complex is designated as part of Waste Area Group (WAG) 3, Operable Unit (OU) 3-13, in accordance with the current remediation management strategy outlined in the FFA/CO. The major components of the ICDF Complex include the following:

- The disposal cells (landfill)

- An evaporation pond, consisting of two cells

- Administration trailer

- Scale

- Decontamination building (with treatment area)

- Contaminated equipment pad

- Staging and storage areas (includes three staging areas, two storage areas, and two other areas to facilitate ICDF Complex operations).

Together, the above components of the ICDF Complex provide centralized waste acceptance, inspection, treatment if necessary, and disposal of CERCLA-generated waste from remediation and deactivation, decontamination, and decommissioning (DD\&D) sites at the Idaho National Laboratory (INL).

The remedial action (RA) activities identified in this work plan, as part of the CERCLA process, will proceed in accordance with the signed OU 3-13 Final ROD and the Remedial Design/Remedial Action Scope of Work for Waste Area Group 3, Operable Unit 3-13 (DOE-ID 2000). This RAWP provides the framework for defining the RA requirements, providing the operational documentation, and defining and implementing the operation of the ICDF Complex. The designs presented in the INEEL CERCLA Disposal Facility Remedial Design/Construction Work Plan (DOE-ID 2002), which describes landfill and evaporation pond design and construction, are also implemented by this RAWP.

The purpose of this ICDF Complex RAWP is to detail the management and operations approach for the ICDF Complex. 


\subsection{Background}

Idaho National Laboratory is located $51.5 \mathrm{~km}(32 \mathrm{mi})$ west of Idaho Falls, Idaho, and occupies $2,305 \mathrm{~km}^{2}\left(890 \mathrm{mi}^{2}\right)$ of the northeastern portion of the Eastern Snake River Plain. The DOE manages INL, which is primarily dedicated to nuclear research, development, and waste management. INTEC, formerly known as the Idaho Chemical Processing Plant, is located in the south-central portion of INL in southeastern Idaho, as shown in Figure 1-1.

The areas surrounding INL are managed by the U.S. Bureau of Land Management and designated for multipurpose use. The developed area within INL is surrounded by a $1,295-\mathrm{km}^{2}\left(500-\mathrm{mi}^{2}\right)$ buffer zone used for cattle and sheep grazing. Private individuals or the U.S. Government owns most of the land surrounding INL. In the counties encompassing INL, approximately $45 \%$ of the land is agricultural and $45 \%$ is open land. In these areas, sheep, cattle, hogs, poultry, and dairy cattle are produced, and potatoes, sugar beets, wheat, barley, oats, forage, and seed crops are cultivated. The remaining $10 \%$ of the land is urban, and the communities nearest to INTEC are Atomic City (south), Arco (west), Butte City (west), Howe (northwest), Mud Lake (northeast), and Terreton (northeast).

From 1952 to 1992, operations at INTEC primarily involved reprocessing spent nuclear fuel from defense projects. Liquid waste generated from the reprocessing activities, which ceased in 1992, is stored in several underground storage tanks at INTEC. These historical operations resulted in both soil and groundwater contamination at the facility. Currently, the Agencies are directing cleanup activities at INTEC to reduce human health and environmental risks to acceptable levels, in accordance with the FFA/CO.

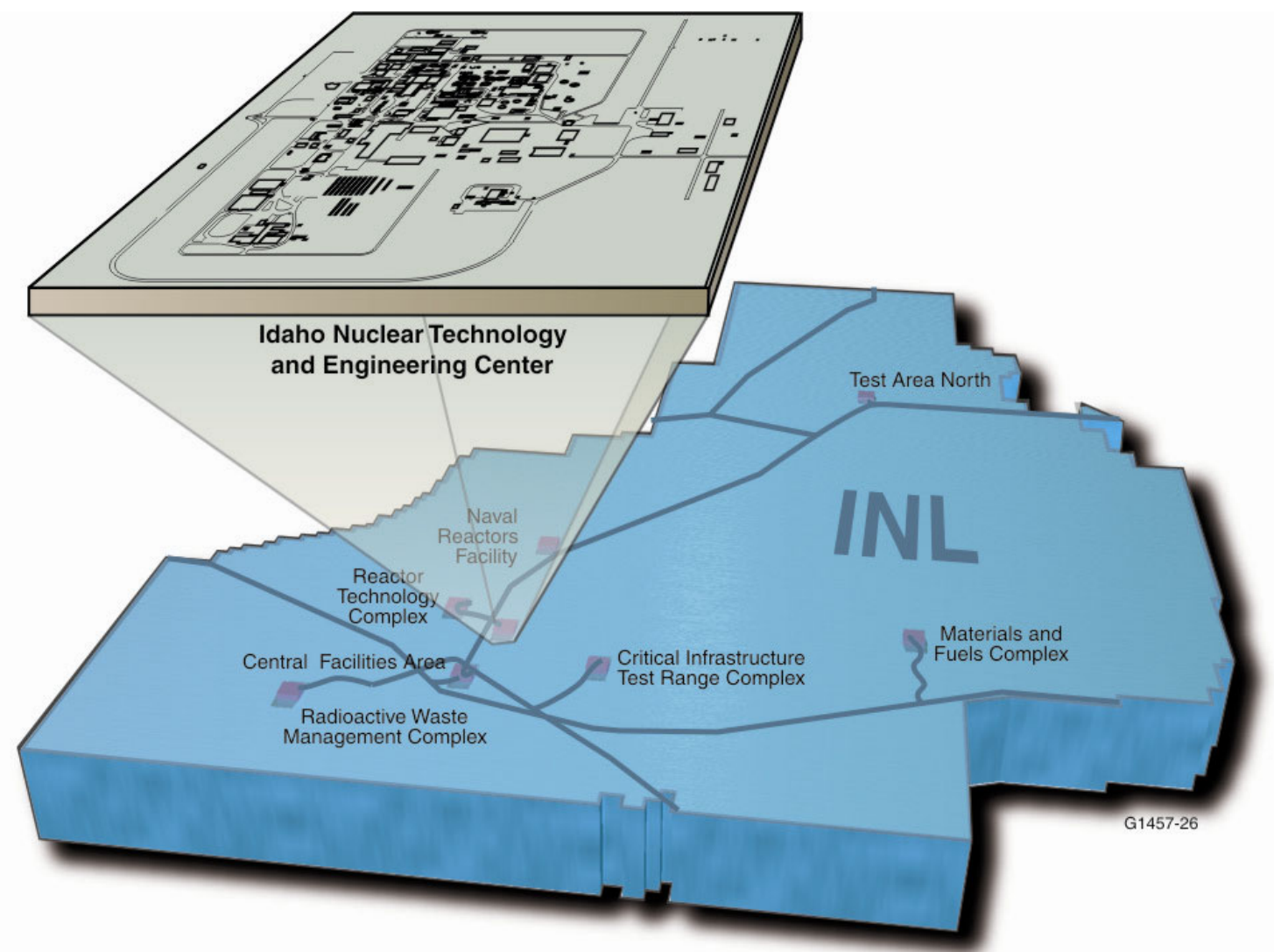

Figure 1-1. Map showing the location of INTEC within the Idaho National Laboratory. 
To facilitate INTEC cleanup, WAG 3 was divided into OUs composed of individual contaminant release sites, and several phases of investigation have already been performed for these OUs. For OU 3-13, a comprehensive remedial investigation/baseline risk assessment (RI/BRA) was conducted to determine the nature and extent of the contamination and the corresponding potential risks to human health and the environment under various exposure pathways and scenarios. The RI/BRA (DOE-ID 1997a) ultimately identified 101 release sites at INTEC that pose a potential risk or threat to human health and/or the environment.

To expedite the development and analysis of RA alternatives for the identified release sites, the sites were arranged into seven groups based on contaminants of concern, accessibility, or geographic proximity. Group 3 within OU 3-13 was designated as "Other Surface Soils." Subsequently, remedy alternatives for "Other Surface Soils," as well as for the other OU 3-13 groups, were evaluated in the Comprehensive RI/FS for the Idaho Chemical Processing Plant OU 3-13 at the INEEL-Part B, FS Report (Final) (DOE-ID 1997b) and the Comprehensive RI/FS for the Idaho Chemical Processing Plant OU 3-13 at the INEEL_Part B, FS Supplement Report (DOE-ID 1998).

The OU 3-13 ROD (DOE-ID 1999) was then developed on the basis of the results of the RI/BRA and the information presented in the comprehensive feasibility study (FS) and FS supplement reports. The OU 3-13 ROD provides selected remedies or interim action until final remedy selection for 55 of the release sites identified by the RI/BRA. (Of 46 other potential release sites identified by the RI/BRA, the ROD designates 40 sites as "No Action" or "No Further Action." The remaining six sites will be managed under other OUs, WAGs, or INL regulatory programs.) The selected remedy for Group 3, "Other Surface Soils," which requires a facility for the treatment and disposal of WAG 3 and other CERCLA waste generated at INL, is described in detail below.

Based on consideration of the requirements of CERCLA, the detailed analysis of alternatives, and public comments, the Agencies selected "Removal and On-Site Disposal" as the remedy for Group 3. As part of this selected remedy, the ICDF Complex will be constructed to allow for on-Site disposal of WAG 3 and other CERCLA-generated wastes at INL. The remediation strategy for the on-Site disposal portion of Group 3 is described in the following primary documents:

- The INEEL CERCLA Disposal Facility Remedial Design/Construction Work Plan (ICDF RD/CWP [DOE-ID 2002]), which describes landfill and evaporation pond design and construction

- $\quad$ This ICDF Complex Remedial Action Work Plan (ICDF Complex RAWP), which describes operations and management aspects of the ICDF Complex (landfill, evaporation pond, and Staging, Storage, Sizing, and Treatment Facility (SSSTF) design and construction.

\subsection{Selected Remedy}

The ICDF Complex is constructed southwest of the INTEC. The ICDF Complex, which includes the main components of the landfill, evaporation pond, and the centralized receiving, storage, treatment, and administration area known as the SSSTF, supplies the necessary subsystems and support facilities to provide a complete waste disposal system (Figure 1-2). 


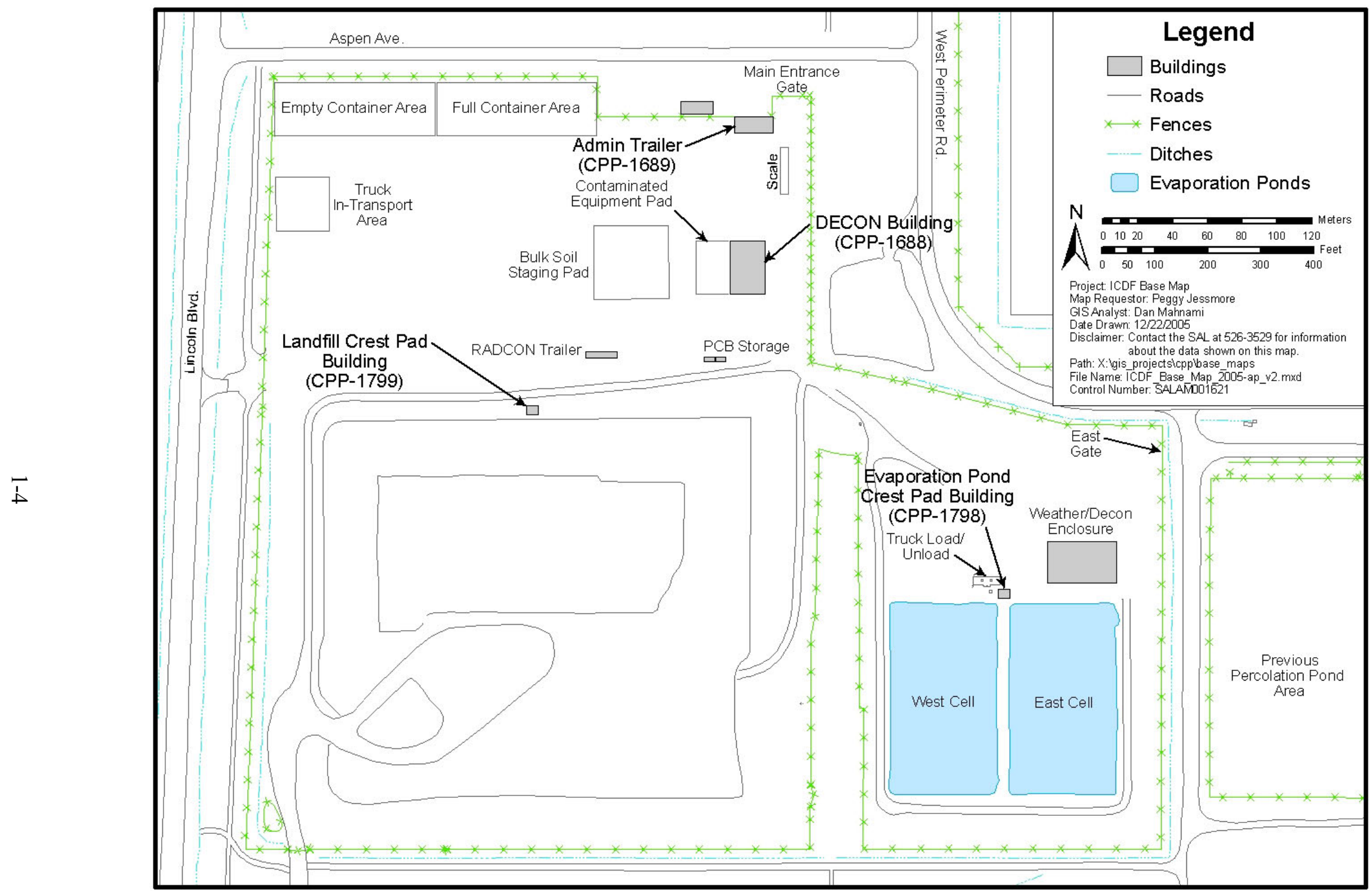

Figure 1-2. Location of ICDF Complex components. 
The ICDF Complex is an integral part of the FFA/CO CERCLA process for INL (DOE-ID 1991). This RAWP establishes the schedule for the ICDF Complex. The priority in the operational schedule for the ICDF Complex will accomplish disposal of waste from thePower Burst Facility, Central Facilities Area, Test Area North, and the Reactor Technology Complex by the end of fiscal year (FY) 2005. The strategic initiatives and objectives pertaining to the ICDF Complex are as follows:

- Accelerate remediation of miscellaneous contaminated units

- Accelerate consolidation of INL facilities and reduce waste footprint

- Continue cleanup and protection of the Snake River Plain aquifer (SRPA)

- Coordinate the operation of the ICDF with other landfills at INL

- Provide cost-effective treatment

- Complete transfer of the ICDF to long-term stewardship by end of FY 2015.

The schedule for the ICDF landfill is to operate the landfill from April through November. This operating schedule provides significant opportunity to coordinate operation of the ICDF landfill with other landfills at INL. These opportunities include equipment and personnel sharing to reduce the INL cost for operating the ICDF landfill and the other landfills.

The ICDF RAWP provides a cost comparison for on-Site treatment and disposal at the ICDF Complex in lieu of off-Site treatment and disposal at a commercial facility. The on-Site treatment and disposal cost at the ICDF Complex is estimated to be $\$ 185 / \mathrm{yd}^{3}$, while the off-Site treatment and disposal cost is $\$ 1,393 / \mathrm{yd}^{3}$ for a disposal volume of $469,000 \mathrm{yd}^{3}$. This cost-effective treatment and disposal cost is one of the reasons the DD\&D program is considering disposal at ICDF Complex. Additionally, all DD\&D waste that enters the ICDF Complex will be CERCLA removal and remedial waste.

This ICDF Complex RAWP presents an operations schedule that projects the last waste to be disposed of in the ICDF landfill by 2013. After the last waste has been disposed of, EPA and DEQ will be notified. Upon this notification, the ICDF Complex closure activities will be initiated. This schedule allows sufficient time to complete the design and construction shutdown-related activities and to complete the transfer of the ICDF to long-term stewardship by the end of FY 2015.

The ICDF landfill is an on-Site, engineered facility for the disposal of hazardous, low-level waste (LLW), mixed low-level waste (MLLW), and polychlorinated biphenyl (PCB)-contaminated soil and debris wastes that (1) are generated by CERCLA remedial and removal actions at INL and (2) meet the landfill waste acceptance criteria (WAC), as specified in the ICDF Complex Waste Acceptance Criteria document (DOE-ID 10881 [DOE-ID 2006a]). The disposal cells, including a buffer zone, cover approximately 40 acres and have a disposal capacity of about $389,923 \mathrm{~m}^{3}\left(510,000 \mathrm{yd}^{3}\right)$. The ICDF landfill meets the substantive requirements of "Resource Conservation and Recovery Act" (RCRA) Subtitle C, "Hazardous Waste Management" (42 USC $\S 6921$ et seq.); "Idaho Hazardous Waste Management Act" (HWMA 1983); "Radioactive Waste Management" (DOE O 435.1); and "Toxic Substances Control Act” (TSCA) (15 USC $\S 2601$ et seq.) PCB landfill design and construction requirements. The ICDF landfill utilizes a modular design consisting of two cells. The ICDF RD/CWP (DOE-ID 2002) describes the design and construction requirements for the ICDF landfill.

ICDF landfill leachate will be disposed of in the ICDF evaporation pond. The ICDF evaporation pond, designated as a Corrective Action Management Unit (CAMU) in the OU 3-13 ROD, is designed and constructed to accept not only ICDF landfill leachate, but also aqueous waste streams from ICDF Complex operations and groundwater monitoring. Specifically, this will include aqueous waste (e.g., purge, sampling, well development, and decontamination water) from WAG 3 and ICDF Complex 
groundwater monitoring that meet the ICDF Complex WAC (DOE-ID 2006a). The ICDF RD/CWP describes the design and construction requirements for the ICDF evaporation pond (DOE-ID 2002).

The SSSTF will be the receiving facility for CERCLA waste for the ICDF Complex. This facility provides areas for waste storage, Complex administration, waste receipt and inspection, and waste treatment for INL CERCLA-generated waste that meets the ICDF Complex WAC (DOE-ID 2006a). Components of the SSSTF include the following:

- Administration trailer

- Scale

- Decontamination building (with treatment area)

- Contaminated equipment pad

- Staging and storage areas.

The decontamination building has been designed and will operate as a containment building in accordance with 40 Code of Federal Regulations (CFR) 264, Subpart DD, "Containment Buildings." The treatment unit and all associated equipment within the decontamination building will be managed in accordance with 40 CFR 264 Subpart DD.

The ICDF Complex staging and storage areas have been designated to provide waste management flexibility during ICDF Complex operations. The areas include the full container staging area, the bulk soil stockpile staging area, and the tank and container storage area. Further details of these areas are provided in the ICDF Complex Operations and Maintenance Plan (O\&M Plan) (DOE-ID 2006b). These areas are shown in Figure 1-2.

Wastes that are awaiting treatment or disposal, or otherwise require staging or storage, will be managed in one of the ICDF Complex staging or storage areas. This management approach is also referred to as the queue approach for ICDF Complex operations. The queue approach simply means that waste will be staged or stored in preparation for treatment, disposal, or off-Site shipment to allow for more efficient operation. This will allow the ICDF Complex to not require full-time dedicated staff and equipment during those times when limited waste operations are ongoing, as necessary. The term "queue" for the ICDF Complex refers to one of the designated waste staging or storage areas where waste will be temporarily held; the term "queued" for the ICDF Complex refers to the management practice of temporarily holding the waste. The actual location for the waste will depend upon the nature and/or containerization of the waste. For example, containers may be queued at the full container staging area awaiting placement in the landfill, or bulk soil may be queued at the bulk soil stockpile staging area awaiting placement in the landfill or treatment.

All ICDF Complex activities take place within the WAG 3 area of contamination to allow flexibility in managing the consolidation and remediation of waste without triggering land disposal restrictions (LDRs) and other RCRA requirements for WAG 3 waste, in accordance with the OU 3-13 ROD (DOE-ID 1999). Only LLW, MLLW, hazardous, and limited quantities of TSCA waste will be accepted for treatment and/or disposal at the ICDF Complex. Transuranic and mixed-transuranic waste can be temporarily stored, treated, and/or packaged at the ICDF Complex until final disposition is determined.

The ICDF Complex will reduce the overall areal extent of soil, liquid, and debris contamination at INTEC and INL, and will achieve cost savings relative to off-Site disposal, or on-Site management, because the contaminated media will be managed in a central facility. Contaminated soils will be 
permanently contained in the ICDF landfill, which is designed and will be operated to ensure long-term protection of human health and the environment. Institutional controls will be maintained at the ICDF Complex as long as necessary to ensure long-term protection. Protection of the groundwater quality in the SRPA has been ensured in the ICDF design. The various components of the ICDF Complex are described in more detail in the ICDF RD/CWP (DOE-ID 2002).

\subsection{Relevant Changes to the OU 3-13 Remedial Design/Remedial Action Scope of Work}

Major elements of the selected remedy relevant to the ICDF Complex are presented in the OU 3-13 Remedial Design/Remedial Action Scope of Work (RD/RA SOW) (DOE-ID 2000). Section 4.3.3 of the RD/RA SOW describes the RD/RA strategy for OU 3-13, Group 3, as an approach that entailed separate, parallel remediation strategies for the SSSTF and the ICDF landfill and evaporation pond. This included preparation of separate OU 3-13 RD/RAWPs and separate RA reports.

In a January 31, 2002, letter, DOE Idaho stated that the documentation for the SSSTF and ICDF landfill and evaporation pond would be combined in this ICDF Complex RAWP to address RA components of the remedies. Previously separate operational and management issues for the SSSTF and ICDF landfill and evaporation pond are now included in this RAWP for the entire ICDF Complex. Furthermore, as a result of the combination of the SSSTF and ICDF landfill and evaporation pond, one RA report is planned to be developed for the ICDF Complex, rather than the separate RA reports described in the RD/RA SOW.

\subsection{Remedial Action Work Plan Organization}

This ICDF Complex RAWP is composed of several sections and appendixes that combine the RA strategies of the SSSTF and the ICDF landfill and evaporation pond to present one complete operational and management strategy for the ICDF Complex.

\subsubsection{Remedial Action Work Plan Organization}

The following are brief descriptions of the Remedial Action Work Plan sections and appendixes:

- Section 1: Introduction. Provides the description of this ICDF Complex RAWP, describes the background and history of INL, INTEC, and WAG 3, and gives an overview of the selected remedy identified in the OU 3-13 ROD (DOE-ID 1999) for the ICDF Complex, as part of Group 3. This section also describes relevant changes to the RD/RA SOW (DOE-ID 2000) that are applicable to the ICDF Complex.

- Section 2: Oversight and Operations Management. Describes the approach for management of the ICDF Complex and the interface between the ICDF Complex management and ICDF Complex users (i.e., WAGs submitting waste to the ICDF Complex).

- Section 3: Protectiveness of the Remedial Action. Discusses various requirements of the ICDF Complex remedy and describes how the operation and maintenance of the ICDF Complex ensures protection of human health and the environment, and fulfillment of CERCLA requirements.

- Section 4: Remedial Action Work Elements. Provides a description of "cradle to grave" waste movement, and the supporting operational activities that will occur as part of ICDF Complex operations. This section is an overview of O\&M details that are provided in the ICDF Complex O\&M Plan (DOE-ID 2006b) and other appendixes to this RAWP. 
- Section 5: Inspections. Provides descriptions of the Agency prefinal and final inspections at the completion of ICDF Complex construction (including a draft prefinal inspection checklist), discusses the prefinal inspection report, and summarizes routine O\&M inspections that will be performed. (Detailed information regarding routine O\&M inspections is presented in the O\&M Plan.)

- Section 6: Reporting and Recordkeeping. Discusses ICDF Complex annual reports that will be submitted to the Agencies for information or review (depending upon the document) and provides information regarding the ICDF Complex RA Report five-year reviews of the remedy performance. The section further presents summary information of the O\&M Plan regarding recordkeeping.

- Section 7: Health and Safety/Emergency Response. Presents an overview of the Health and Safety program for O\&M activities at the ICDF Complex. This section also addresses the ICDF Complex approach for emergency response. Training requirements for ICDF Complex employees is briefly discussed, with further details provided in the Health and Safety Plan for Idaho CERCLA Disposal Facility Operations (HASP) (INL 2006).

- Section 8: Waste Management Plan. Presents an overview of the ICDF Complex Operations Waste Management Plan (WMP) (DOE-ID 2006c). The WMP provides the operational waste streams that may be generated from the ICDF Complex and the management strategy for these wastes.

- Section 9: Closure Requirements. Presents the applicable or relevant and appropriate requirements (ARARs) identified as being related to closure of the ICDF Complex and discusses the closure approach for each of the components of the Complex in relation to the ARARs.

- Section 10: Project Schedule and Cost Estimate. Summarizes the schedule for the ICDF Complex RA presented in Appendix N, and summarizes the cost estimate update and on-Site versus off-Site comparisons for the ICDF Complex.

- Section 11: Community Involvement. Documents the community involvement activities conducted by INL for the ICDF Complex to date and provides information regarding the approach for future community involvement and public relations.

- Section 12: References. Lists the referenced material from the body of the RAWP.

- The appendixes included in this RAWP, such as engineering design files (EDFs) and separate DOE Idaho documents, have separate reference sections.

\subsubsection{Remedial Action Work Plan Appendixes}

The RAWP appendixes include the following:

Appendix Volume 1 of 2-Idaho CERCLA Disposal Facility Complex Operations and Maintenance

- Appendix A: ICDF Complex Operations and Maintenance Plan (DOE/ID-11000 [DOE-ID 2006b]). Provides operational and management details of the ICDF Complex. The sections in the O\&M Plan describe the operational organization for the ICDF Complex, provide environmental compliance requirements and operational limits, and describe monitoring that will be performed. Operational tasks, including waste tracking, receipt, treatment, staging, storage, and disposal, are also described to provide the necessary detail for ICDF Complex operations. Waste management designations are assigned to various components of the ICDF Complex, and operational details are given for management of those components. The O\&M Plan also addresses maintenance, facility configuration 
control, inspections, notifications and data submittals, and records management to provide a comprehensive approach for ICDF Complex operations and maintenance. The O\&M Plan includes two appendixes. Appendix A, Procedure Overviews, provides summaries of applicable regulatory requirements for operational and maintenance procedures that will be developed by INL for the ICDF Complex. Appendix B, Equipment List, provides a listing of all necessary major pieces of equipment that are used for the ICDF Complex operations.

Appendix Volume 2 of 2 - Operational Information and Project Management

- Appendix B: ICDF Waste Profile and Verification Sample Guidance (DOE/NE-ID-11175 [DOE-ID 2005]). Replaces the original ICDF Complex Material Profile Guidance and the ICDF Complex Waste Verification Sampling and Analysis Plan, which have been combined into one document. Assists generators with characterization of waste streams destined for disposal at the ICDF Complex and development of a Material Profile. The overall goal of waste characterization and Material Profile development for the ICDF Complex is to obtain a conservative but appropriate way to (1) characterize waste for entry into the ICDF Complex, (2) ensure compliance with the appropriate waste acceptance criteria (WAC), and (3) facilitate disposal at the ICDF landfill or evaporation pond. Verification is required to confirm that the key parameters in the waste (i.e., those parameters that limit acceptance of waste in the landfill as defined by ICDF WAC and/or operational limits) do not exceed the specifications of the Waste Acceptance Criteria.

- Appendix C: "Waste Tracking Plan for the Idaho CERCLA Disposal Facility Complex" (PLN-914). Provides detailed descriptions of the waste tracking process. The waste tracking process is described from its inception at the remediation site with the ICDF Complex user through final disposal at the ICDF landfill or evaporation pond, or shipment off-Site. Provides information regarding cumulative waste inventory accumulation in the landfill and associated transfers to the evaporation pond. A system description is provided as an appendix to the Waste Tracking Plan to describe the electronic database that will be used for waste tracking.

- Appendix D: (ICDF Complex Waste Verification Sampling and Analysis Plan [DOE/ID-10985]). This document has been replaced by the ICDF Waste Profile and Verification Sample Guidance (DOE/NE-ID-11175), which was combined with the ICDF Complex Material Profile Guidance into one document; see Appendix B.

- Appendix E: "INEEL CERCLA Disposal Facility Short-Term Risk Assessment" (EDF-ER-327). Assesses the potential unmitigated exposure risks posed by the ICDF Complex to individuals who visit or work on or near the Complex. Mitigation measures that can be used to control workplace exposures at the Complex are presented but not included in the evaluation calculations.

- Appendix F: Health and Safety Plan for Idaho CERCLA Disposal Facility Operations (INEEL/EXT-01-01318 [INL 2006]). Provides the plan for health and safety at the ICDF Complex to ensure protection of workers and visitors. Spill prevention, response, and training requirements for the ICDF Complex also are addressed in the HASP.

- Appendix G: ICDF Complex Operations Waste Management Plan (DOE/ID-10886 [DOE-ID 2006b]). Describes the operational waste streams that may be generated from the ICDF Complex and the management strategy for these wastes.

- Appendix H: INEEL CERCLA Disposal Facility Groundwater Detection Monitoring Program: Data Analysis Plan (DOE/ID-10998 [DOE-ID 2003a]). Describes the approach that will be used to evaluate groundwater data collected in support of the ICDF Complex detection monitoring 
program. The detection monitoring program will evaluate the groundwater monitoring data for statistically significant evidence of contamination from the ICDF Complex.

- Appendix I: Treatability Study Test Plan for Soil Stabilization (DOE/ID-10903 [DOE-ID 2003b]). Discusses the objectives and methods of conducting treatability studies on waste material. The wastes are primarily soils containing radionuclides and heavy metals. The treatment method described is a Portland cement-based chemical fixation system that stabilizes the contaminants in a nonleachable form. Treated waste samples will be analyzed to determine if the treated material would meet disposal criteria.

- Appendix J: Sampling and Analysis Plan for SSSTF Waste Stabilization Operations (DOE/ID-10924 [DOE-ID 2003c]). Provides the Sampling and Analysis Plan (SAP) for wastes that are treated at the ICDF Complex for on-Site disposal. The purpose of the sampling and analysis is to ensure that all stabilized soils meet "Alternative LDR Treatment Standards for Contaminated Soils" (40 CFR 268.49) prior to their disposal in the ICDF landfill. The document describes two sampling strategies. In the first, stabilized soil from treatability studies will be sampled and analyzed to verify the stabilization mixture and process. In the second, samples of stabilized soils will be analyzed for batches of soil following full-scale treatment to confirm the results of the stabilization process.

- Appendix K: "NESHAP Compliance Demonstration for the ICDF Complex" (EDF-2236). Describes the calculation approach and methodology to determine the annual National Emission Standards for Hazardous Air Pollutants (NESHAP) emissions from ICDF Complex sources. NESHAP emissions are used as input to calculate the potential dose for the maximally exposed individual (MEI) for INL, using the CAP-88 computer code. The MEI dose is reported annually in the INL NESHAP Annual Report.

- Appendix L: "IDAPA Air Compliance Demonstration for the ICDF Complex" (EDF-2237). Develops the ICDF Complex operational limits to meet DEQ toxic air pollutant standards. The operational limits are developed using both an emissions model and a dispersion model to meet requirements for nonradionuclide constituents. The modeled system includes O\&M of the ICDF landfill, evaporation pond, and SSSTF.

- Appendix M: ICDF Complex Operational and Monitoring Sampling and Analysis Plan (DOE/ID-11005 [DOE-ID 2003d]). Provides information about sample collection, sample analysis, and quality assurance/quality control that will be used for the ICDF landfill leachate, evaporation pond liquid and sediment, and pump station liquid during operational monitoring activities.

- Appendix N: "Project Schedule and Assumptions." Provides the project working schedule for operation of the ICDF Complex. The schedule includes all activities up to submittal of additional closure documentation.

- Appendix O: "INEEL CERCLA Disposal Facility Complex On-Site Versus Off-Site Cost Comparison" (EDF-2385). Provides an estimate of the total projected costs for operation of the ICDF Complex, and compares the costs of on-Site treatment and disposal to off-Site treatment and disposal. Also presents the cost of on-Site treatment with off-Site disposal.

- Appendix P: "Responses to Comments." Provides Agency comments that were received for the Draft Final ICDF Complex RAWP (and all appendixes) and provides the resolution and/or incorporation approach of the comments in the Final ICDF Complex RAWP (and all appendixes). 


\section{OPERATIONAL OVERVIEW}

The ICDF Complex may accept any INL CERCLA-generated waste that meets the ICDF Complex WAC (DOE-ID 2006a) and has an approved Waste (Material) Profile (developed using guidance provided in DOE-ID 2005). This includes waste generated as a result of CERCLA RAs, investigation derived waste, and waste from removal actions for which the ICDF Complex has been identified as the disposal/treatment pathway. Waste from DD\&D activities associated with a recognized CERCLA action also may be sent to the ICDF Complex. All DD\&D waste that enters the ICDF Complex will be CERCLA waste.

The ICDF Complex, including the evaporation pond, storage/staging and administration functions, will be operational year round. The landfill will be operated when weather conditions allow proper waste placement, approximately from mid- to late March through mid-November. The treatment unit will operate during the winter months, when waste campaigns warrant its operation, and anytime during slack periods, depending on landfill scheduling.

\subsection{Waste Identification, Loading, and Acceptance}

This section provides the operational overview for waste identification, loading, and acceptance.

\subsubsection{Waste Identification}

Before a waste can be considered for acceptance into the ICDF Complex, the ICDF Complex user must first initiate contact with the ICDF Complex management. The ICDF Complex user will identify the waste type, complete a Waste (Material) Profile according to the ICDF Waste Profile and Verification Sample Guidance (DOE-ID 2005), and verify that the waste stream is appropriate for receipt at the ICDF Complex. The ICDF Complex personnel will work with the ICDF Complex user to ensure the waste meets the appropriate WAC requirements and to set the waste schedule and acceptance processes in motion. If the waste cannot be accepted at the ICDF Complex, the ICDF Complex user will be informed and referred to other INL personnel for aid in locating an appropriate disposition pathway.

Once a waste stream has been identified as CERCLA, has an accepted Waste Profile, and has been found acceptable for entry into the ICDF Complex, the waste tracking system is implemented, as outlined in the ICDF Waste Tracking Plan (PLN-914). The ICDF Complex user then initiates the waste generation. Waste estimates suggest that approximately $70 \%$ of the waste destined for the ICDF Complex will be shipped as bulk waste either in roll-on/roll-off containers, dump trucks, other approved containers (e.g., boxes, drums, or containers), or as bulk debris. Liquid waste destined for the evaporation pond will be shipped in containers or tanker trucks or may be transferred directly to the evaporation pond via piping. (The use of drums for liquid waste is discouraged, although drums containing liquid waste may be accepted at the ICDF Complex.) Landfill leachate from the ICDF landfill will be pumped to the evaporation pond through the landfill and evaporation pond crest pad building and the leachate collection system piping. Other aqueous waste generated as a result of ICDF Complex operations may be transferred to the ICDF evaporation pond through the decontamination building (pump station) or may be containerized and transported to the evaporation pond.

\subsubsection{Loading Operations}

During loading operations, the container is pulled up to the loading hoe or other apparatus. For bulk waste, the roll-on/roll-off container or truck may be lined with plastic. (This plastic liner will form a "burrito bag" to reduce contamination of the container and aid in dust control.) Waste is then loaded by 
the ICDF Complex user. The ICDF personnel will supervise the collection of the verification sample(s), using the process outlined in the ICDF Waste Profile and Verification Sample Guidance (DOE-ID 2005).

After being loaded, the truck will pull into a field screening station at the remediation site. This radiological field screening is not conducted to support verification sampling; rather, it is performed to ensure that contamination control is maintained. While the field screening is taking place, the burrito bag (if present) will be sealed, and then the container will be covered. The ICDF representative will ensure that the Waste Tracking Form (WTF) is correct and includes the appropriate bar code(s) and approvals. (The WTF may be either an electronic or hard copy.) A unique bar code will be assigned to each waste load or container to facilitate the tracking of the waste through the system. The truck will proceed from the ICDF Complex user site to the ICDF Complex where the driver will present the WTF.

\subsubsection{Waste Acceptance}

The WTF is the receiving and admission form for access into the ICDF Complex. No waste shipment will be allowed through the gate without this form. The delivery truck with the container will enter the ICDF Complex gate, and the WTF will be inspected for completeness and accuracy. Prior to being driven onto the scale, the container will be visually inspected for loose contamination and free liquid. If the form is in order, the truck and/or container may move onto the scale.

If the form does not agree with the ICDF Complex tracking information, the truck will be sent to the truck in-transport area (shown in Figure 1-2) until the discrepancies can be resolved. A waste load will not be held in this holding area for more than 10 working days. If the discrepancy cannot be corrected within 10 working days, the waste will be returned to the generator, assuming the shipment back to the generator would not violate Department of Transportation (DOT) regulations. The return of the waste to the generator will require the generating site to have the capability of accepting the returned waste. The waste in the truck in-transport area may be moved into ICDF Complex staging or storage areas, as long as the waste meets the criteria for these areas.

\subsection{ICDF Complex Operational Scenarios}

This section discusses the operational scenarios for waste placement and disposition.

\subsubsection{Waste in Roll-on/Roll-off Containers}

Roll-on/roll-off containers are the preferred delivery forms for waste shipped to the ICDF Complex, as the use of these containers provides more versatility and allows for faster receipt and off-loading of waste at the facility. The driver will pull onto the scale and then be directed to the holding queue where the container will be off-loaded (DOE-ID 2006b). The WTF will be placed in a sleeve on the roll-on/roll-off container, and the truck will be surveyed for contamination. After a radiological control technician has released the vehicle, it will pick up an empty roll-on/roll-off container from the empty container area. (Radiological Control [RadCon] will have released these containers prior to their being put in the empty container area.) The vehicle, having never entered the landfill, will return to the ICDF Complex user site to pick up another load.

A shuttle truck from the landfill will pick up the container from the queue and transport it to the landfill. The shuttle truck will approach the dump face and be directed by the landfill personnel to the actual dump location. The tarp covering the shipment will be loosened and the driver given approval to dump the load. At this time, landfill personnel will record the grid location of the waste on the WTF. At the end of a shift, or periodically during the day, WTFs will be delivered to the administration building 
and be entered into the Integrated Waste Tracking System (IWTS). Additional information about the IWTS and the waste tracking for this operational scenario is provided in PLN-914.

As the driver dumps the load, landfill personnel will spray the dump face to control dust and add water necessary for compaction. After the initial lift placement, the bulldozer will be operating at the level below the dump face, spreading the waste as it exits the truck. The burrito bag will be disposed of with the waste. Once unloaded, the shuttle truck and container will be scanned and either released or decontaminated within the landfill. The shuttle truck will then take the empty roll-on/roll-off container to the empty queue and off-load it. The shuttle will then pick up a full roll-on/roll-off container and proceed again to the landfill.

\subsubsection{Waste in Dump Trucks}

If bulk soil arrives in a dump truck, the driver will be directed either to a holding queue or directly to the landfill, after the WTF has been inspected for completeness and accuracy.

The unloading process at the dump face for dump trucks will be the same as that for the roll-on/roll-off containers. At the dump face, the truck will be surveyed for contamination, and, if clean, will exit the landfill. If this is the first load that the particular truck has delivered, the truck must proceed to the truck scale and weigh empty before exiting the ICDF Complex.

If the truck is contaminated, decontamination procedures that can be conducted within the landfill will be implemented. If the truck cannot be decontaminated with these procedures, then it will be moved to the decontamination building and subjected to more rigorous decontamination procedures. Only after RadCon personnel have released the truck will the truck be allowed to exit the ICDF Complex.

\subsubsection{Containerized Waste}

Some waste will enter the landfill in boxes, drums, or other containers. A barcode will be attached to each separate container for tracking purposes. Containerized waste will enter the gate and the WTF will be checked for completeness and accuracy. Depending on the waste, the landfill schedule, and final disposition of the waste, the truck will be either off-loaded into a storage area, sent directly to the landfill, or sent to the decontamination building for possible repackaging.

Waste in wooden boxes will be placed in the landfill in accordance with the applicable rigging and hoisting requirements. The boxes will be crushed in place during the compaction process. Other containers may be off-loaded near the dig face to await the appropriate compaction conditions, as outlined in the "Waste Placement Plan" (EDF-ER-286).

Waste that is off-loaded into the storage areas will be placed into the landfill as appropriate to compliment the compaction requirements and landfill schedules. The WTFs will be put in sleeves on the container and remain with the container until the waste has reached final disposition.

Once the waste has been placed in the landfill, the waste location will be recorded on the WTF and sent to the administration building for recording.

Solid waste containers may be decontaminated, if necessary, to meet free-release criteria and allow for reuse. Containers can be reused until such time that container integrity is questionable. When the containers are deemed no longer usable, they will be disposed of in the landfill, as long as they meet the appropriate ICDF Complex WAC (DOE-ID 2006a). 


\subsubsection{Waste Awaiting On-Site Disposal}

Bulk waste in staging areas will be tracked in the same manner as containerized waste, with tracking numbers associated with each waste stream. The WTFs will be held in the administration office until the waste has been treated and/or moved into the landfill. The date of the waste placement in the staging area will be recorded on the WTF, and the waste will not remain in the area longer than two years. When the waste is disposed of, the location within the landfill cell will be entered on the WTF and returned to the administration building for recording.

Waste staging requirements are further detailed in Section 5 of the ICDF Complex O\&M Plan (DOE-ID 2006b). Containerized waste awaiting disposal will be handled in accordance with Section 4.4.2 of this document.

\subsubsection{Waste Awaiting Off-Site Disposal}

It is the policy of the ICDF Complex to deny waste that cannot be disposed of or treated within the facility. However, waste may be generated within INL that has no identifiable disposition pathway. For such waste, storage at the ICDF Complex may be the best option. The waste is required to be put in appropriate containers, as required in the ICDF Complex WAC (DOE-ID 2006a) prior to being shipped to the ICDF Complex. In addition, the waste would go through the same tracking and inspection procedures as any other waste received at the ICDF Complex.

If such a waste is stored at the ICDF Complex, other INL personnel will be contacted immediately to begin the process of locating an appropriate disposition pathway.

Waste awaiting off-Site disposal would be stored in either the SSA or the tank and container storage area, as shown in Figure 1-2. Additional information about waste storage units is provided in Section 5 of the O\&M Plan (DOE-ID 2006b).

\subsubsection{Aqueous Waste}

There are basically two types of aqueous waste for disposal in the ICDF evaporation pond. The first is wastewater from WAG 3 CERCLA groundwater activities, brought to the ICDF Complex in tanker trucks or in containers on flatbed trucks. The waste will be loaded at the well head, and a WTF will accompany the waste load to the facility in much the same way that the form accompanies bulk soils. The WTF will be checked for completeness and accuracy at the ICDF Complex gate. Because the volume of the waste will be recorded in gallons, the load will not be weighed. Once the waste has been allowed through the gate, the driver will be directed to the evaporation pond. The truck or tank will then discharge the load into the appropriate cell of the evaporation pond via the truck unloading pad.

The second type of aqueous waste is waste generated within the ICDF Complex (i.e., the leachate, decontamination water, and washdown water). These types of waste will be piped directly to the evaporation pond. The waste volume will be recorded electronically through a series of totalizers and flow meters.

Aqueous waste will be either disposed to the evaporation pond, stored for off-Site treatment and/or disposal in the SSA or the tank and container storage area, or it could be used in the waste treatment process at the ICDF Complex as makeup water. The process for waste treatment at the ICDF Complex is described in Section 4 and Appendix A of the O\&M Plan (DOE-ID 2006b). 
Aqueous waste containers may be decontaminated, if necessary, to meet free-release criteria and allow for reuse. Containers can be reused until such time that container integrity is questionable. When the containers are deemed no longer usable, they will be disposed of in the landfill, as long as they meet the landfill WAC (DOE-ID 2006a).

\subsection{Waste Treatment Operational Scenarios}

This section provides the operational scenarios for ICDF Complex waste treatment.

\subsubsection{Waste Requiring Treatment to Meet Land Disposal Restrictions}

Although waste requiring treatment will be received throughout the year, the treatment unit will operate primarily during the winter months, or during slack time, depending on the landfill schedule. This waste may be received in bulk shipments or containers. Waste destined for treatment will be staged or stored at one of the waste management units until the treatment unit is ready to begin the campaign.

Bulk waste will be moved into the decontamination building in load sizes appropriate for treatment. The waste will be loaded into the treatment unit, treated, and unloaded into a container (most likely a roll-on/roll-off container). The containerized, treated waste will then be subjected to the QA sampling outlined in the SAP for SSSTF Waste Stabilization Operations (DOE-ID 2003c). Treated waste will be stored until the landfill schedule allows for disposal, which will occur only after the appropriate sampling results have been verified and received.

As waste is off-loaded from the staging or storage areas, it will be shuttled into the landfill as appropriate to compliment the compaction requirements and landfill schedules. The WTFs will be put in sleeves on the container and remain with the container until the waste has reached final disposition.

Once the waste has been placed in the landfill, the waste location will be recorded on the WTF and sent to the administration building for entry into the IWTS.

\subsubsection{Debris}

Debris that requires treatment prior to being disposed of will be treated as outlined in EDF-1730, "Staging, Storage, Sizing, and Treatment Facility Debris Treatment Process Selection and Design." If placement has been triggered, debris treatment standards will apply to debris contaminated with hazardous waste. Waste tracking during storage will be the same as outlined in Section 4.1.6 of this RAWP.

\subsection{Waste for Repackaging}

It is the ICDF Complex policy to deny waste that is not in appropriate packaging. However, some INL waste streams may possibly require repackaging, and repackaging facilities will be provided within the decontamination building. At the present time, no such waste has been identified for receipt at the ICDF Complex. If a waste were to be identified, the ICDF Complex management would first contact the ICDF Complex user prior to shipment. If the issues cannot be resolved with the ICDF Complex user, the waste may be accepted into the ICDF Complex for repackaging and shipment off-Site. 


\subsection{Environmental Compliance}

Environmental compliance with all waste handling and storage requirements is addressed in detail in Section 4.8 of this RAWP. Monitoring requirements for the ICDF Complex also are addressed in this section. 


\section{PROTECTIVENESS OF THE REMEDIAL ACTION}

below.

The protectiveness of the selected RA for key components of the ICDF Complex is discussed

\subsection{Waste Acceptance Criteria}

Throughout the remedy selection and design phases of the ICDF Complex, it has been recognized that one of the most critical tools for the protection of the environment is the development of limitations regarding what wastes can be accepted into the ICDF Complex. To this end, DOE Idaho and the Agencies have worked to develop WAC that will ensure the protection of human health and the environment. As the individual WACs have been combined into one document, a discussion of the protectiveness of each section of the documented WAC (ICDF Complex, ICDF landfill, and ICDF evaporation pond) is provided in the following sections.

\subsubsection{ICDF Complex Waste Acceptance Criteria}

The general waste acceptance criteria for the ICDF is addressed within the ICDF Complex WAC document (DOE-ID 2006a) and was developed to identify the types and quantities of waste allowable for receipt, staging, storage, and treatment that will be protective of human health and the environment. The objectives of these criteria are to ensure the following:

- Only those waste types that are within the agreed-upon limitations enter the ICDF Complex

- Waste types that enter the ICDF Complex have been screened and determined to be within the limits that have been deemed protective

- Waste within the ICDF Complex will not exceed the allowable limits for the protection of the SRPA per the OU 3-13 ROD (DOE-ID 1999) requirements

- The commitments in the OU 3-13 ROD are met and maintained

- The waste received at the ICDF Complex contains only the radionuclides and hazardous constituents that the facility can safely manage

- The concentrations and/or total activities of the waste received at the ICDF Complex are compatible with the design and operational limits

- Waste received at the treatment unit can be treated and disposed of at the ICDF Complex while maintaining protectiveness

- The waste received at the ICDF Complex is in a form or container that will maintain its integrity and retain acceptable configuration under the conditions expected to be encountered during ICDF Complex operations and closure

- Waste received at the ICDF Complex does not contain materials that will compromise the safety or integrity of the facility under the expected operating conditions.

Implementation of the ICDF Complex WAC will ensure compliance with applicable regulatory and ROD requirements established for protection of human health and the environment, including the SRPA. 


\subsubsection{ICDF Landfill Waste Acceptance Criteria}

Specific ICDF landfill WAC (DOE-ID 2006a) was developed to identify the types and quantities of waste allowable for placement in the landfill that will be protective of human health and the environment. The objectives of the ICDF landfill WAC are to ensure the following:

- Waste placed within the ICDF landfill will not exceed the allowable limits for the protection of the SRPA

- Human and ecological receptors will be prevented from exceeding a cumulative carcinogenic risk of $1 \times 10^{-4}$ and a total hazard index of 1

- Exceedances of maximum contaminant levels in the SRPA will be prevented

- Waste received at the ICDF landfill will contain only the radionuclides and hazardous constituents that the facility can safely manage

- The concentrations and/or total activities of the waste received are compatible with the ICDF landfill design and operations parameters

- Waste received does not contain materials that will compromise the safety or integrity of the facility, including the landfill liner system, under the expected operating conditions.

\subsubsection{ICDF Evaporation Pond Waste Acceptance Criteria}

The ICDF evaporation pond WAC (DOE-ID 2006a) was developed to identify the types and quantities of liquid waste allowable for storage/evaporation that will be protective of human health and the environment. The objectives of the ICDF evaporation pond WAC are to ensure the following:

- The waste received at the ICDF evaporation pond contains only the radionuclides and hazardous constituents the facility can safely manage

- The concentrations and/or total activities of the waste received at the ICDF evaporation pond are compatible with the ICDF evaporation pond design and operations parameters

- Aqueous waste does not contain materials that will compromise the safety and integrity of the facility under the expected operating conditions.

Waste types allowable in the evaporation pond include leachate from the ICDF landfill, purge and development water from monitoring well drilling and sampling operations, secondary aqueous waste generated from waste processing, and decontamination activities in the decontamination building.

\subsection{Groundwater Monitoring}

To ensure that the ICDF Complex RA is protective of groundwater, a detection monitoring system was installed in the SRPA that meets the substantive requirements of 40 CFR 264 Subpart F of the RCRA, "Releases from Solid Waste Management Units." Detailed information on the detection monitoring program can be found in the ICDF Complex Groundwater Monitoring Plan (DOE-ID 2004). Water samples will be collected and analyzed from perched water and the SRPA to monitor for releases from the ICDF landfill and evaporation pond. The detection monitoring network consists of five downgradient aquifer monitoring wells that have been constructed, and one existing upgradient well. 
Six new perched water wells, with a maximum of three completions in each borehole, were installed. To establish background contaminant concentrations, four rounds of samples were collected from the SRPA monitoring wells. Another sample was taken in May 2003 prior to ICDF Complex startup. Perched water was found in three of the 18 perched water sampling zones, and four rounds of baseline samples were collected. Due to the limited extent of perched water and the decrease in perched water observed since use of the percolation ponds was discontinued in August 2002, a decision on whether perched water will be part of detection monitoring was made by the Agencies in spring 2003, following evaluation of the perched water data. After startup, samples from the detection monitoring network and from the perched water wells were collected semiannually for indicator parameters. Once every 2-1/2 years, samples from perched water and SRPA monitoring wells will be analyzed for a more comprehensive list of analytes.

Although not part of the RCRA Subpart F (40 CFR 264) detection monitoring program, routine monitoring will occur for the leachate collection and recovery system, and the primary and secondary leak detection and recovery system (DOE-ID 2003d). These data, along with water level data and data from existing wells, will be used as lines of evidence to determine whether a release has occurred from the ICDF landfill or evaporation ponds. The data may also be valuable during modifications of the list of indicator parameters that will be monitored semiannually.

A Data Analysis Plan (DOE-ID 2003a) for the SRPA is included as Appendix H of this RAWP. This plan describes the approach that will be used to evaluate groundwater data collected in support of the ICDF Complex detection monitoring program to ensure that groundwater is protected. Currently, the Data Analysis Plan addresses the evaluation of the groundwater data associated with the SRPA wells.

These precautions, along with the ICDF Complex WAC (DOE-ID 2006a), ensure the protectiveness of the ICDF Complex RA.

\subsection{Final Landfill Cover}

The final landfill cover system is required to minimize infiltration and run-on and maximize run-off, as well as protect against inadvertent intrusion for greater than 1,000 years. These requirements have been incorporated into the design of the final landfill cover system, which is a key component to the protection of human health and the environment following closure of the landfill. The landfill cover has been designed to minimize infiltration, thus protecting the SRPA groundwater resources. The cover system has also been designed to contain the waste and prevent exposures to the waste through the use of natural earthen materials that will last well beyond the 1,000-year minimum life.

The landfill cover complies with identified ARARs and, in most cases, exceeds the minimum regulatory requirements. The cover system exceeds the requirements of 40 CFR 264.310, "Closure and Post-Closure Care," regarding minimum requirements for landfill covers. The cap has been designed to reduce infiltration through the combination of two different processes:

- Evapotranspiration layer to promote run-off and evapotranspiration

- Barrier and drainage layer to direct infiltration off the cover system and minimize infiltration into the waste.

The evapotranspiration layer consists of $9 \mathrm{ft}$ of fine-grained loam material. This layer is designed to store precipitation during wet periods and then allow evaporation or transpiration of stored water during dry periods. This system can function very well in arid environments to minimize infiltration into the landfill. Previous studies at INL and Hanford have shown that, for typical years of rainfall, zero infiltration will occur with this evapotranspiration cap system. 
Regulatory requirements require the barrier and drainage layers. These layers are a secondary system that reduces infiltration into the landfill from something that could penetrate the evapotranspiration layer. This barrier system consists of $2 \mathrm{ft}$ of clay liner material overlain by a drainage media to promote run-off away from the landfill waste. In combination, these two systems provide a minimum of infiltration and minimize any potential impacts to the SRPA.

The minimum cover thickness will be $17.5 \mathrm{ft}$ when constructed. The cover materials have been designed to provide protection against intrusion for greater than 1,000 years. The biointrusion layer, which consists of cobble-size rock, will prevent burrowing animals from penetrating the barrier layer of the cap. All layers of the cap have been designed to provide natural filtering so materials cannot be washed through the cobbles and compromise the cover system. This thick cap system will prevent any exposure to waste or the potential for inadvertent exposure to contamination.

\subsection{Storm Water Pollution Prevention}

Design and construction of the ICDF Complex has incorporated storm water pollution prevention practices to ensure protection of human health and the environment. In accordance with the ROD ARARs (40 CFR 122.26, "Storm Water Discharges"), storm water pollution prevention will be implemented during ICDF Complex construction using the "Storm Water Pollution Prevention Plan for the ICDF Landfill and Evaporation Pond" (PLN-962) and the "Storm Water Pollution Prevention Plan for Construction Activities - Staging, Storage, Sizing, and Treatment Facility Phase I" (PLN-1034). During operations, pollution prevention practices will be utilized to ensure this RA remains protective of human health and the environment. 


\section{REMEDIAL ACTION WORK ELEMENTS}

This section of the RAWP identifies the work elements required to operate the ICDF Complex. As in most RAWPs, this section provides only a summary of the detailed information presented in supporting sections or documents that are part of this ICDF Complex RAWP. The location and reference for the supporting information is included in the text to assist the reader in finding the desired level of information. This section summarizes the following RA work elements:

- Waste tracking: the entire waste tracking process for waste that will enter, leave, or be processed at the ICDF Complex. Waste tracking is an operational work element that follows waste from generation to disposal (or shipment off-Site).

- Remediation site activities: a summary of remediation site activities as they relate to ICDF Complex operations. Remediation site activities occur prior to waste transport to the ICDF Complex.

- Waste shipment and delivery: the process of transporting and delivering waste to the ICDF Complex. Waste shipment and delivery occurs prior to waste being received at the ICDF Complex.

- $\quad$ Predisposal operations: the receipt, inspection, weighing, storage or staging, treatment if needed, and repackaging of waste that enters the ICDF Complex. Predisposal operations refer to all activities that occur prior to waste disposal in the ICDF landfill or evaporation pond.

- Landfill: all required work elements that are necessary to place various waste types in the ICDF landfill.

- Evaporation pond: all required work elements that are necessary to place or transfer various waste types, including leachate, secondary aqueous waste generated as part of ICDF Complex operations, and other WAG 3 aqueous waste types (e.g., purge, sampling, and well development water), to the ICDF evaporation pond.

- Maintenance: the maintenance activities that will be performed to support ICDF Complex operation. Maintenance activities are ongoing throughout the operational period of the Complex.

- Environmental compliance and monitoring: the environmental compliance and monitoring strategy that will be implemented for the ICDF Complex. Environmental monitoring and compliance are continuous activities that will be performed throughout the ICDF Complex operations.

- Closure: the closure approach for the ICDF Complex that will be implemented at the end of the operational period, and the process for development of additional closure information for the Complex.

\subsection{Waste Tracking}

Waste will be tracked at the ICDF Complex using IWTS. Used across the INL to track LLW, MLLW, and hazardous waste, IWTS is a replicated client-server application distributed on numerous INL servers. The IWTS will be used at the ICDF Complex to track (1) wastes entering the Complex, (2) treatment (e.g., microencapsulation, stabilization, repackaging), (3) disposal (e.g., landfill, evaporation pond), (4) generation (e.g., personal protective equipment [PPE], contaminated maintenance waste, decontamination waste), and (5) off-Site shipment. This will ensure that complete, generation-to-disposition waste tracking is performed. The IWTS provides documentation regarding 
source, waste characterization, and hazardous and radioactive constituents. The IWTS will provide source data for the development of regulatory, management, and waste operations reports and to support Web-based reporting activities. Geographic Information System services will use the IWTS data to generate a three-dimensional grid map, which will show the location of each load dispositioned in relationship to the permanent bench marks.

Tracking of waste destined for disposal at the ICDF Complex will begin at the ICDF Complex user's dig site and end with final disposition (e.g., disposal, off-Site shipment). A detailed description of the waste tracking process and IWTS is provided in the Waste Tracking Plan for the ICDF (PLN-914). An overview of the waste tracking process is provided in Figure 4-1.

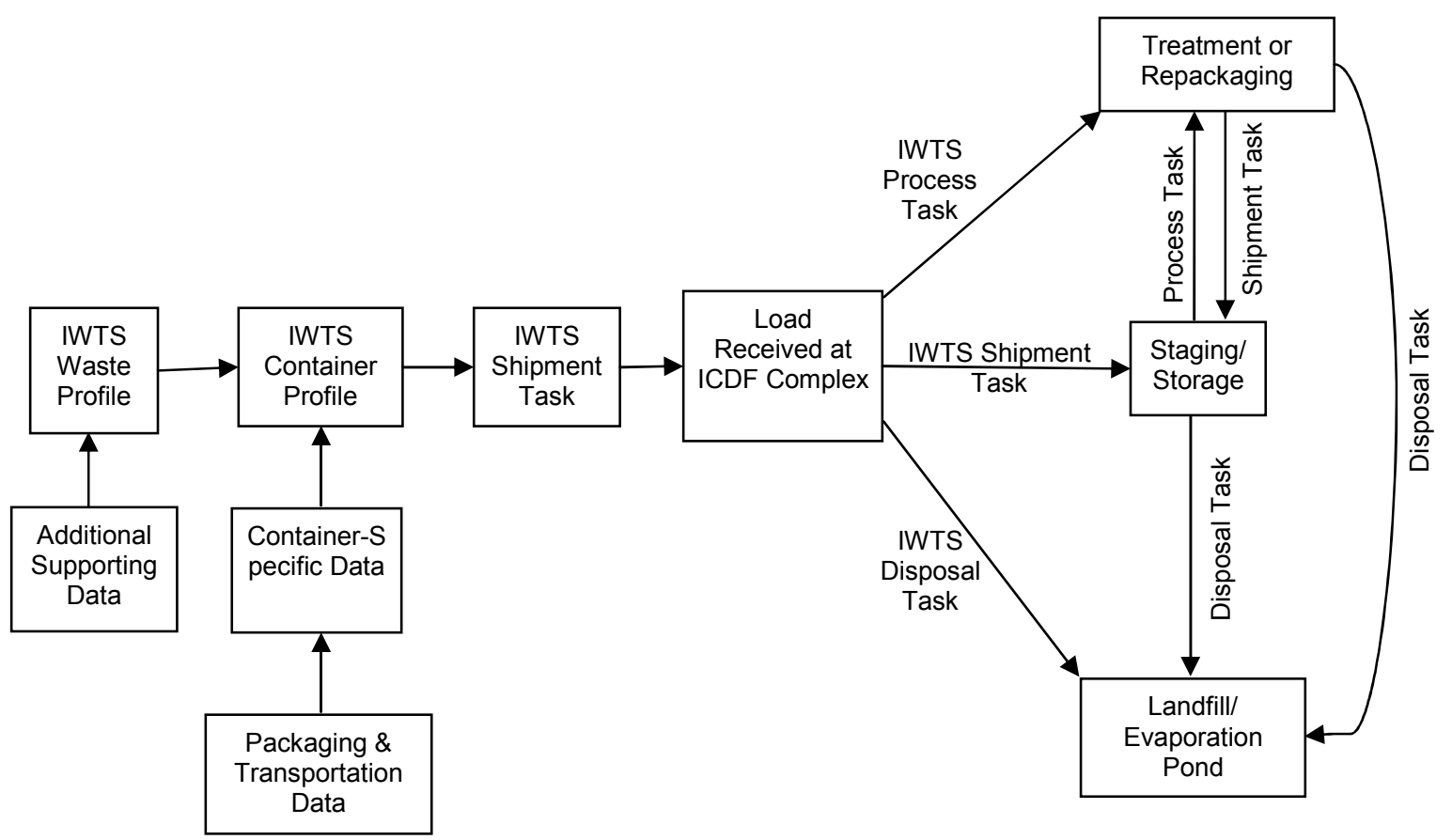

Figure 4-1. The ICDF Complex waste tracking process.

\subsubsection{Identification of Waste to be Sent to ICDF Complex}

Characterization of all waste submitted for acceptance into the ICDF Complex is the responsibility of the ICDF Complex user. The ICDF Complex user may use either acceptable knowledge or sampling and analysis to characterize waste. Acceptable knowledge includes both historical data and process knowledge. An explanation of acceptable knowledge and the appropriate use thereof are explained in the ICDF Complex WAC (DOE-ID 2006a).

Before waste is accepted into the ICDF Complex, an IWTS Material Profile (Waste Profile) must be completed by the ICDF Complex user and provided to the ICDF Complex management. In addition, the waste must be on the ICDF Complex schedule. 
All ICDF Complex users must provide project schedules to the ICDF Complex management for planning purposes. At a minimum, the required information includes the waste volume, general class of waste, primary waste forms, potential radioactive and hazardous constituents, applicable listed waste codes, expected waste disposition pathway, and special handling requirements, including any anticipated need for treatment. Table 4-1 lists the major planning steps (and corresponding timeframes) that ICDF Complex users must complete to send waste to the ICDF Complex.

Table 4-1. Schedule for CERCLA project and ICDF Complex interaction.

\begin{tabular}{lc}
\hline \multicolumn{1}{c}{ Information } & $\begin{array}{c}\text { Due Date for Information from } \\
\text { ICDF Complex User to } \\
\text { ICDF Complex Management }\end{array}$ \\
\hline $\begin{array}{l}\text { Project name, proposed schedule, and waste type } \\
\text { Material Profile entered into IWTS }\end{array}$ & 6 months before anticipated ship date \\
$\begin{array}{l}\text { Shipping schedule (number of trucks/containers } \\
\text { per day) and days of shipment }\end{array}$ & 1 month before anticipated ship date \\
\hline
\end{tabular}

\subsubsection{Waste Acceptance into the ICDF Complex}

The ICDF Complex user completes an IWTS Material and Waste Characterization Profile (referred to as the Waste Profile, or Material Profile) for each waste stream. The Material Profile documents all chemical, radiological, and physical characteristics of a waste stream. The IWTS automatically assigns the Material Profile a unique identification number, beginning the process of electronic tracking of the waste. Once the Material Profile has been approved by the ICDF Complex, the ICDF Complex user has approval to send the waste stream to the Complex, provided the waste is within the WAC limits and the verification sampling and analysis have been conducted.

An IWTS Container Profile is used to track individual containers of waste belonging to a waste stream identified by and electronically tied to the Material Profile. A "container" in IWTS is defined as a parcel of waste with a defined volume and/or weight, such as a box, dump truck, roll-off box, or drum. The Container Profile identifies all chemical, radiological, and physical characteristics for each container. These characteristics are entered as specific values that are encompassed by the maximum/minimum ranges of the associated Material Profile.

The ICDF Complex user completes a Container Profile for each container of waste for shipment to the ICDF Complex. A unique barcode number is applied to the container and used as the identifier when the corresponding Container Profile is created in IWTS. The IWTS automatically ties the container to the waste stream using this barcode and the Material Profile's identification number. This barcode number identifies the physical container and electronically ties it to the appropriate Container Profile. After both the Material and Container Profiles are approved, the waste will be assigned a shipping date to the ICDF Complex.

\subsubsection{Waste Packaging and Shipment}

The ICDF Complex user is required to properly package, mark, and label waste per the ICDF Complex WAC (DOE-ID 2006a) and DOT regulations (if applicable). In addition, the user is responsible for prearranging the delivery time and date of all waste shipped to the ICDF Complex. The unique barcode number assigned to the container when the Container Profile was completed is applied at the time of packaging. All waste packaged for shipment to the ICDF Complex will be visually inspected by ICDF 
personnel before shipment to ensure: (1) the waste matches the approved Material and Container Profiles, (2) the waste does not contain prohibited material (e.g., free liquids), (3) void space requirements are met (if applicable), and (4) the containers are compatible with waste contents.

Before shipping the waste, the ICDF Complex user completes an IWTS Shipment Task. The container barcode numbers, shipping date and time, originating facility, receiving unit, certification/approval, and other container and shipment-specific information are entered on the IWTS Shipment Task. Before the physical shipment leaves the generating site, necessary updates (e.g., shipment date and time) to the Shipment Task area input, and the "execute send" portion of the Shipment Task is completed. In addition, individual WTFs are printed for each container on the Shipment Task. WTFs accompany each container to the ICDF Complex and are turned over to ICDF Complex personnel along with the container. The applicable Waste Tracking Form for ICDF is Form 435.95 and is available on EDMS.

\subsubsection{Waste Receipt}

Upon arrival at the ICDF Complex, the electronic documentation and paperwork accompanying each shipment of waste will be checked, at a minimum, for the correct Material Profile number, correct Container Profile numbers, designated number of containers and/or correct volume of waste, adequacy of shipping documentation, and appropriate marking and labeling of containers. After the shipment has been receipt-inspected, ICDF Complex personnel sign off on the WTF as shipment accepted, and electronically accept the waste by completing the "shipment received" portion of the IWTS Shipment Task. (Additional waste receipt tasks not associated with the waste tracking process are further described in Section 4.4 of this RAWP.)

\subsubsection{Waste Designation}

The shipment is considered received at the ICDF Complex when ICDF Complex personnel accept the shipment electronically in IWTS. Once the waste is received, various IWTS tasks are created, depending on whether the waste will be stored, staged, treated, repackaged, or directly disposed of.

4.1.5.1 Waste Staging and Storage. Waste arriving at the ICDF Complex may be managed for a variety of reasons, such as awaiting treatment, pending identification of treatment capacity, or awaiting disposal. An IWTS Shipment Task would be used to electronically move the waste from receiving into the SSSTF storage area, or into the ICDF staging area. Upon physical receipt of the shipment at the ICDF, storage or staging locations are assigned for each container and noted on the WTF. This information is input into IWTS, ensuring that the precise location of the waste within the storage or staging area is documented.

4.1.5.2 Waste Treatment/Disposal. An IWTS Disposal Task is used to track waste being disposed of at the ICDF Complex. If the waste meets the ICDF landfill WAC, the waste may be taken directly from the receiving area to the ICDF landfill for placement. Disposal of waste that has first been stored, staged, or treated at the ICDF Complex follows the same tracking process. The only difference is that the originating facility for the Disposal Task will be the storage, staging, or treatment area from which the waste is coming. The WTF accompanies the waste to the landfill, and the specific grid where the waste is placed is noted on the form. Each Disposal Task in the IWTS identifies the landfill grid coordinates for each container or load deposited. This information is updated when the task is executed and accepted, ensuring that the precise location of the waste within the landfill is documented.

WAG 3 aqueous waste that meets the evaporation pond WAC may be sent directly to the pond for treatment/disposal, or stored and/or treated first. An IWTS Disposal Task is used to electronically move 
the waste from receiving (or storage) into the evaporation pond. The process is the same as described above for the landfill, except the receiving location will be the evaporation pond. The cell where the waste is disposed of is noted on the WTF for entry into IWTS, similar to the landfill grids. Waste sent for off-Site disposal is tracked in a similar fashion, with the off-Site Treatment, Storage, and Disposal Facility (TSDF) designated as the receiving facility.

4.1.5.3 Waste Processing. Upon receipt, waste may be processed at an ICDF Complex treatment unit. Processing options at the ICDF Complex include either stabilization, debris treatment, or repackaging. Waste not meeting the landfill or evaporation pond WAC may be sent to a treatment unit. An IWTS Process Task will be used to electronically transfer waste (e.g., constituents and associated quantities) and any regulatory designations (e.g., EPA codes, underlying hazardous constituents) from an original container into a receiving/destination container. When treatment of the waste is completed, a Shipment Task will be used if the receiving/destination container is to be placed into storage; a Disposal Task will be used if the receiving/destination container is to be sent to the landfill.

Waste being shipped to an off-Site TSDF may require repackaging into containers that meet DOT packaging requirements, or repackaging to meet the off-Site WAC. Waste may be removed from the parent container and placed in an appropriate new container, or the original container may be over-packed into a new container. This work will be conducted in the decontamination building and may be performed in either the treatment area or decontamination bay. An IWTS Processing Task is used to track waste undergoing repackaging, as described above.

\subsubsection{Inventory Tracking and Compliance Limits}

Inventory histories for all ICDF storage, staging, treatment, and disposal locations will be used to provide real-time data on the current inventory and ensure compliance with facility limits (operational, WAC, etc.). Location-specific inventories are maintained by physical properties (individual container identification number, total container count, total volume and weight, etc.), radiological properties (fissile material, individual radionuclides and activities, etc.), and chemical properties (constituents and amounts, etc.). Accurate inventory tracking relies on the timely creation and completion of transactions (e.g., Shipment and Disposal Tasks).

Numerous compliance checks (physical, radiological, chemical and other, operational, etc.) have been built into the IWTS system. "Physical Inventory" checks include gross and net weight, gross and net volume, and container count. "Radiological Inventory" checks include fissile material, less than DOE safety category III, and user-defined nuclides. "Chemical and Other Inventory" checks include threshold quantities, threshold planning quantities, reportable quantities, flammable material, and user defined materials. "Operational Inventory" checks include LDRs, Idaho Administrative Procedures Acts (IDAPAs), NESHAPs, groundwater contaminants of concern, and transuranic radionuclide concentration. Limit compliance reports have been prepared for each of the limits identified above and are available for the various locations at the ICDF Complex. Limit evaluations are electronically stored for each task and provide objective evidence demonstrating limit compliance.

\subsubsection{Reporting}

The IWTS contains many standardized reports accessed directly in the software. These reports deal with the day-to-day operations of the ICDF Complex such as inventories, limit compliance, and process and disposal activities for specified locations. Other reports, such as regulatory-driven or management-level reports, are obtained through Microsoft Access or web-based applications. Section 9 of the ICDF Complex O\&M Plan (DOE-ID 2006b) provides an example of required reports for the ICDF Complex that may be supported by IWTS data. 


\subsubsection{Response Action}

Waste received at the ICDF Complex with noncompliant conditions shall require appropriate resolution before waste acceptance. Resolution alternatives may include, but are not limited to, correction of the noncompliant condition at the ICDF Complex, conditional acceptance of the waste at the ICDF Complex, or staging at the truck in-transport area for up to 10 days until resolution of the issue. If the discrepancy cannot be rectified within 10 working days, the waste will be returned to the generator, assuming that shipment back to the generator would not violate DOT regulations. Return of waste to the generator will require the generating site to have capability of accepting these returned wastes. Waste in the truck in-transport area may be moved into ICDF Complex staging or storage areas, as long as the waste meets the criteria for these areas.

In addition to short-term rectification of the noncompliant condition to allow disposition, further steps shall be taken to determine the underlying cause of the problem and implement corrective actions as necessary to prevent recurrence. A recurrence of noncompliant shipments from an ICDF Complex user may result in rejection of the waste and termination of shipments until the issues have been resolved.

ICDF Complex management will work with the generating WAG to resolve noncompliant conditions in a timely manner. Resolution may include contacting the generating WAG to correct discrepancies on the Material Profile, obtaining more information, correcting mislabeling, etc. In addition to resolution of the noncompliant conditions, further steps will be taken to determine the underlying cause of the problem and implement corrective actions as necessary to prevent recurrence. Recurrence of noncompliant shipments from a generating WAG may result in rejection of the Material Profile and termination of shipments until the issues have been resolved.

\subsubsection{Records Management}

All waste tracking records will be kept on file at the ICDF Complex as outlined in the FFA/CO (DOE-ID 1991). Detailed information on the ICDF Complex records management system, including a list of documents to be kept, is provided in Section 10 of the O\&M Plan (DOE-ID 2006b).

\subsection{CERCLA Remediation Site Activities}

Several remediation site activities take place in advance of waste receipt at the ICDF Complex, including waste characterization, waste removal, and waste packaging and staging. These remediation activities will be performed in accordance with the ICDF Complex user's Agency-approved documentation (e.g., RD/RAWP) and are not considered part of ICDF Complex operations. Waste verification will be supervised by the ICDF Complex. A summary of these activities is discussed below to provide an understanding of the complete waste process from generation to disposal and to describe the interface between the ICDF Complex operations and the ICDF Complex user's remediation activities.

\subsubsection{Waste Characterization}

Waste characterization of all waste destined for the ICDF Complex will be performed by ICDF Complex users; it is the responsibility of the users to characterize the waste in accordance with the ICDF Complex WAC (DOE-ID 2006a). The ICDF Complex user may apply either acceptable process knowledge, use analytical data, or use a combination of both these methods to characterize the waste as outlined in the ICDF Complex WAC. Potentially, additional sampling and analysis of waste destined for the ICDF Complex may be needed as part of characterization. In accordance with the FFA/CO (DOE-ID 1991), additional sampling and analysis will be performed by the ICDF Complex user in accordance with a remediation site's RD/RAWP field sampling plan, or other remediation/sampling documentation. 
Sampling and analysis documentation and analytical data, if needed, is the responsibility of the ICDF Complex user and is not the responsibility of the ICDF Complex. Most remediation sites have characterization data obtained through Track 2 or remedial investigation (RI) sampling events. However, additional characterization may be performed by the ICDF Complex users to support ICDF Complex waste acceptance or health and safety issues just prior to or at the time of remediation.

Characterization data will be used to prepare Waste Profiles; these processes are explained in ICDF Complex Waste Profile and Verification Sample Guidance (DOE-ID 2005) and the Waste Tracking Plan (PLN-914).

\subsubsection{Waste Removal}

Once an ICDF Complex user has a Waste Profile for a particular waste stream, and has been given a waste shipping schedule from the ICDF Complex, waste excavation will begin at the individual remediation site. Remediation activities will be performed in accordance with that remediation site's approved RD/RAWP, or other appropriate FFA/CO documentation. Waste removal will not be the responsibility of the ICDF Complex or conducted in accordance with any ICDF Complex requirements.

\subsubsection{Waste Verification}

The waste verification requirements are described in detail in the ICDF Complex Waste Profile and Verification Sample Guidance (DOE-ID 2005). The purpose of this plan is to provide guidance for the sample collection and analyses required to verify that waste destined for ICDF Complex disposal meets the applicable WAC, and that waste concentrations do not exceed the applicable waste acceptance criteria for the waste stream.

The objective of the waste verification sampling activity is to ensure that all soil waste entering the ICDF Complex and destined for disposal in the ICDF landfill is within the WAC and other operational limits. Verification samples will be collected to ensure that the samples are representative of the waste to be to be sent to the ICDF Complex.

For waste that exceeds $80 \%$ of the landfill WAC mass limits, laboratory analyses for key waste constituents will be performed. Waste shipment will be delayed to receive results from the verification sampling.

Verification also will be performed to observe the potential for free liquid when the potential exists for free liquid to be generated. Further information regarding free liquid verification is provided in Section 4 and Appendix A of the O\&M Plan (DOE-ID 2006b).

\subsubsection{Waste Packaging and Waste Area Group Staging}

Waste will be packaged at the remediation site, using containers that are acceptable for receipt at the ICDF Complex, in accordance with the ICDF Complex WAC (DOE-ID 2006a). Once the waste is packaged, the remediation site may choose to stage the waste at or near the remediation site to streamline the transportation process to the ICDF Complex. All waste packaging and WAG staging will be performed by ICDF Complex users in accordance with the ICDF Complex user's Agency-approved remediation documentation and are not considered part of ICDF Complex operations. 


\subsection{Waste Shipment and Delivery}

The ICDF Complex is authorized to accept only CERCLA waste from INL activities consistent with the OU 3-13 ROD (DOE-ID 1999). Prior to any waste being shipped to the ICDF Complex, the ICDF Complex user must receive authorization from the ICDF Complex management to ship waste. The ICDF Complex will prearrange the delivery time and date of all waste shipped. Waste will not be accepted into the ICDF Complex unless it is accompanied by the proper documentation as described in Section 4.1 of this RAWP.

Approximately $70 \%$ of the waste will be shipped as bulk soils, either in dump trucks or roll-on/roll-off containers. Other types of containers may include boxes and drums. Roll-on/roll-off containers are preferred, as they provide more versatility and allow for faster receipt and off-loading of the waste. Section 4.2 of the O\&M Plan (DOE-ID 2006b) provides more details about waste loading and transportation processes.

\subsubsection{Waste Loading for Shipment}

Waste loading will be conducted in a manner that is protective of human health and the environment. Since bulk shipments may account for $70 \%$ of the waste shipped to the ICDF Complex, most of these shipments are anticipated to be in roll-on/roll-off containers. Prior to being loaded, each container will be inspected to verify that it is in good condition with no signs of severe corrosion, structural damage, or defects that may affect integrity. The containers will be evaluated to ensure they are compatible with the waste. A liner may be inserted into each container to aid in sealing the container. Waste will be loaded carefully and methodically to prevent loss of waste. After waste is loaded and verification samples are collected as necessary, the container liner will be closed and sealed. A cover will be secured over the roll-on/roll-off container or dump truck bed as a further protective measure. The loads will remain closed during shipment. Smaller quantities of waste may be packaged in drums or boxes. Waste Area Group 3 aqueous waste will be loaded and shipped in tanks, tanker trucks, or other approved containers.

Each waste container will be appropriately labeled and given an attached barcode so it can be tracked through IWTS, as described in Section 4.1 of this RAWP.

\subsubsection{Waste Transport to Complex}

Waste that will be transported to the ICDF Complex will adhere to all relevant EPA, DOT, and INL requirements to ensure that safety, health, and environmental protection is achieved and maintained during transport of the remediation site waste. Waste shipments that must be transported across or on public roadways will meet DOT and INL transportation requirements. Waste transported only within the boundaries of the INL and transported on INL-owned roadways to the ICDF Complex will adhere to all applicable INL transportation requirements.

\subsection{Predisposal Operations}

The ICDF Complex provides centralized receiving, staging, storage, inspection, and treatment necessary for various INL CERCLA wastes prior to disposal in the ICDF landfill or evaporation pond, or shipment off-Site. These activities are termed predisposal operations, as they occur prior to ICDF landfill or evaporation pond disposal. The following sections provide information about the work elements that will be performed as part of predisposal operations. Section 4 of the O\&M Plan (DOE-ID 2006b) provides additional detail. 


\subsubsection{Waste Receipt and Inspection}

Waste receipt will begin with an approved Waste Profile. The Waste Profile will be received and approved by ICDF Complex management prior to the waste's arrival. A completeness check will be performed on the Waste Profile to ensure that the waste meets the appropriate WAC. Ideally, the Waste Profile will be submitted 3 months prior to waste shipment. The ICDF Complex user may resubmit an unacceptable Waste Profile after corrections have been made. Details of the waste approval process are presented in PLN-914, "Waste Tracking Plan for the Idaho CERCLA Disposal Facility Complex."

If the Waste Profile has been accepted, the generator will be notified and assigned a shipping date. On the assigned shipping date, waste will be received and inspected at the ICDF Complex gate. The approved Waste Profile must be available at the ICDF Complex administration offices prior to waste arrival. A WTF will accompany the load and be checked at the ICDF Complex gate. Waste received at the gate will be verified upon entry; this will involve a cross check against the incoming Waste Profile and inspections consisting of checks on the number of containers, type of container, and container labeling. Containers will be visually inspected to ensure the container integrity is intact and there are no visible signs of free liquid for solid waste streams. Additional receipt inspections may take place on a random basis as determined by ICDF Complex management/personnel.

\subsubsection{Waste Staging and Storage}

Waste awaiting treatment and/or disposal will be staged or stored at one of the designated staging or storage areas for the ICDF Complex. The SSA provided storage for solid and liquid waste prior to the ICDF Complex becoming operational.

It is the ICDF Complex policy that if waste cannot be disposed of in the landfill or the evaporation pond, then it will not be accepted into the ICDF Complex. However, there may be certain waste streams for which immediate disposition pathways do not exist. In this case, a limited quantity of waste awaiting off-Site disposition may be stored at the ICDF Complex. Waste that cannot be treated to meet the ICDF landfill WAC with the available treatment processes will be moved into one of the storage areas in preparation for off-Site disposal.

Section 5 of the O\&M Plan (DOE-ID 2006b) describes the various storage and staging areas, provides operational information for each of these areas, and describes the design of the areas to meet applicable or relevant and appropriate regulatory requirements (ARARs). Section 5 of the O\&M Plan also presents detailed information regarding the staging and storage areas, including the following:

- The storage and staging areas will meet substantive RCRA requirements that provide for hazardous waste control.

- A location for storage of PCB-contaminated waste in a prefabricated storage unit will be provided.

- Inspections of staging and storage areas containing waste will be performed and documented. Inspections are further detailed in Section 8 of the O\&M Plan.

- Spill control and cleanup measures will be invoked when a container has been breached and appropriate spill notifications and paperwork will be completed, as described in Section 9 of the O\&M Plan. 
Staged waste may be in containers or stockpiles. Containerized or stockpiled waste will be managed according to the requirements of 40 CFR 264.554, "Staging Piles," which specifies that staging areas must facilitate a reliable, effective, and protective remedy and be designed to be protective of human health and the environment. As part of the design of the ICDF Complex staging and storage areas, preparation includes grading and gravel or asphalt surface to promote run-on/run-off control. Bulk soil waste will be placed on liners. Appendix A of the O\&M Plan (DOE-ID 2006b) describes the operation of the bulk soil stockpile staging area. Containers and stockpiled waste will be labeled or identified by signage. Stockpiles will remain covered except during placement or removal of waste. Incompatible wastes will be segregated into separate containers or piles. Staged waste will not be staged for more than 2 years. If waste staging is anticipated to exceed the 2-year period, an extension will be requested in accordance with 40 CFR 264.554, and as described in Section 5 of the ICDF Complex O\&M Plan. Staging and storage areas will be cleaned as necessary after wastes are removed. Staging areas will be reused until the closure of the ICDF Complex, as described in Appendix A of the O\&M Plan. Section 5 of the O\&M Plan provides additional operational information related to waste storage and staging.

\subsubsection{Waste Stabilization/Treatment}

Waste stabilization or treatment may be necessary for solid, aqueous liquid, or sludge waste entering the ICDF Complex. The purpose of treatment is to stabilize, treat, or otherwise prepare INL CERCLA waste that either requires treatment to meet LDRs or does not meet the ICDF landfill or evaporation pond WAC for final disposal in the ICDF landfill or at an off-Site disposal facility. Portland cement will be the primary binding agent for stabilizing the waste, although additional admixtures may be used for chemical fixation. The object of cement-based stabilization is to produce a treated waste that will (1) reduce the contaminant leachability to LDR/universal treatment standard concentrations to meet the ICDF landfill WAC, and (2) exhibit no free liquid.

The Treatability Study Test Plan for Soil Stabilization (DOE-ID 2003b) describes the methods that will be used to conduct treatability studies for individual waste streams received at the ICDF Complex for treatment.

The treatment process for soil stabilization is designed to treat contaminated soil and aqueous liquid and sludge. These waste types will be stabilized using a Portland-cement-based mixture as described in the Treatability Study Test Plan (DOE-ID 2003b). Liquid and sludge will be evaluated to determine if they might be used as makeup/addition water for the stabilization process. This would provide the benefit of stabilizing the hazardous constituents in the aqueous waste and reducing the clean, makeup water in the cement-based mixture. However, sludge will not be treated as a separate waste stream.

For batches of treated waste and the treatability study samples created in accordance with the Treatability Study Test Plan, the SAP for SSSTF Waste Stabilization Operations (DOE-ID 2003c), describes the sampling and analysis that will be performed for those waste types that are treated at the ICDF Complex prior to disposal in the ICDF landfill. The purpose of the sampling and analysis is to ensure that all stabilized soils meet "Alternative LDR Treatment Standards for Contaminated Soils" (40 CFR 268.49) prior to their disposal in the ICDF landfill. Two sampling objectives are described in the SSSTF Waste Stabilization Operations SAP: (1) the analysis of treatability study samples to verify the stabilization mixture and process, and (2) the analysis of samples of stabilized soils for each batch of soil following full-scale treatment to confirm the results of the stabilization process. 


\subsubsection{Debris Treatment}

Treatment of hazardous debris subject to 40 CFR 268.45, "Treatment Standards for Hazardous Debris," will be performed at the decontamination building using Portland-cement-based microencapsulation for debris waste that requires treatment prior to disposal. The "SSSTF Debris Treatment Process Selection and Design" (EDF-1730) describes the selected microencapsulation technology that will be used to perform debris treatment.

Microencapsulation with inorganic materials was selected as the primary debris treatment process for the debris waste that requires treatment at the ICDF Complex prior to disposal in the ICDF landfill. The performance specification for microencapsulation is to reduce the leachability of the hazardous contaminants, primarily metals, on the debris. This treatment process will be performed in a nonintrusive, nonlabor-intensive manner to reduce exposure potential to workers conducting the treatment. The ICDF landfill WAC further requires that all waste disposed of to the landfill has a compressive strength of at least 50 psi. Mockup treatment campaigns will be used to demonstrate that the treatment process can achieve this requirement.

To perform the debris treatment, holes will be cut in the top of the box. If the nature of the container prevents cutting holes in the box, another method of entry to the box will be created. Debris treatment will be performed using appropriate INL radiological procedures and engineering controls, as necessary, based upon the waste to be treated. The grout pump nozzle will be placed in the box and the cement grout will be slowly pumped into the box until the box is filled with grout. The cement grout will be allowed to cure, after which a forklift will place the box on a flatbed truck to be transported to the ICDF for placement. The box also may be transported to one of the ICDF Complex waste staging areas.

Additional information regarding the debris treatment process is described in EDF-1730.

\subsubsection{Waste Repackaging}

Waste at the ICDF Complex may require repackaging under the following circumstances:

- If a container is not in good condition and/or the container is ruptured or leaks, the container will require repackaging.

- Waste that is being shipped to an off-Site TSDF or a facility designed to accept LLW may require repacking into containers that meet appropriate regulatory shipping requirements. Although the ICDF Complex WAC allows for acceptance of INL CERCLA waste requiring off-Site shipment, the ICDF Complex will only accept such waste if circumstances necessitate its storage at the ICDF Complex (e.g., small quantity wastes that would be better managed at an existing facility rather than at a separate storage area established at the generating site). There may be instances where repackaging the waste at the ICDF Complex is the most practical solution.

Waste may be removed from its original container and placed in an appropriate new container or may be "overpacked" into the new container. This work will be conducted in the decontamination building and may be performed in either the treatment area or decontamination bay.

\subsubsection{Decontamination Building}

The ICDF Complex decontamination activities will take place at the decontamination bay in the decontamination building. Radiological and hazardous contaminants on waste transport vehicles, waste containers, and miscellaneous equipment will be removed as needed. The decontamination bay will be 
equipped with a high-pressure water sprayer for additional wet decontamination as necessary. Equipment and containers will be decontaminated and checked for external radiological contamination for purposes of release from the ICDF Complex in accordance with INL procedures. All trucks and equipment leaving the ICDF Complex will be verified to meet free-release criteria according to INL policy. Water from the decontamination building is drained through an oil/water separator and then pumped directly to the evaporation pond. Section 4 and Appendix A of the O\&M Plan (DOE-ID 2006b) provide additional information about the operations of the decontamination bay and the oil/water separator.

\subsection{Landfill Operations}

The ICDF landfill provides a centralized, engineered disposal location for INL CERCLA-generated waste that meets the landfill WAC (DOE-ID 2006a). This section provides a summary of the operational work elements that will be performed as part of the RA. The RA work elements described in this section include summary implementation information related to waste shuttle to the landfill, waste off-loading and compaction, dust control, and radiological surveys to release equipment and containers from the landfill. Additional information related to landfill operations is provided in Section 4 and Appendix A of the O\&M Plan (DOE-ID 2006b).

The majority of waste to be placed in the ICDF landfill is soil and soil-like material. Additional waste materials that meet the ICDF landfill WAC, including building debris, concrete (monoliths and rubble), and containerized material (boxes and drums) will be accepted. Building demolition debris includes beams (steel and concrete), concrete rubble, pipe, etc. There is a potential for overpacked drums to be placed in the landfill. If these overpacked drums are identified for disposal at the ICDF landfill, specific placement methods, such as grouting the void space in the overpack, will be implemented to conform to WAC requirements. The ICDF Complex WAC (DOE-ID 2006a) provides the requirements for appropriate waste containers for the ICDF Complex.

\subsubsection{Waste Shuttle to Landfill}

Waste shuttle is the movement of waste from the ICDF staging areas, located near the decontamination building and administration trailer, to the ICDF landfill dump face where the waste is to be off-loaded. This operation applies to bulk soil and debris waste that is dumped at the work face, as well as containerized waste, PCB waste, asbestos, and monoliths.

Additional ICDF landfill waste shuttle information is presented in Section 4 and Appendix A of the O\&M Plan (DOE-ID 2006b).

\subsubsection{Waste Off-Loading/Placement}

Waste off-loading may consist of dumping soil or, in the case of containers, unloading the truck with the use of multiple pieces of equipment. Once the truck has been off-loaded, a survey for radiological contamination will be performed. The truck will be directed back to the staging area if it meets the free release criteria for external contamination (or decontaminated in the disposal cell area or decontamination building, if it is contaminated).

Waste placement will be performed in accordance with EDF-ER-286, the "Waste Placement Plan." Waste placement in the ICDF landfill considers the proper waste positioning in the landfill, relative to the landfill liner, landfill sides, and eventual landfill cover system for waste. The Waste Placement Plan was developed to ensure that waste placement activities in the ICDF landfill are consistent with design requirements for settlement and stability. 
Section 4 and Appendix A of the O\&M Plan (DOE-ID 2006b) provide additional operational information for waste off-loading and placement.

\subsubsection{Waste Compaction}

Waste compaction is the compaction of waste and soil in the ICDF landfill to minimize the chance of subsidence of the final cover. When debris and soil are off-loaded at the dump face, a dozer will move the waste away and spread it across the grid(s). The dozer operator will pass over the waste repeatedly to provide compaction. Compaction water may be sprayed on the waste soil during compaction passes; the volume of compaction water will be minimized so as to only use the amount necessary to achieve compaction. The compaction water source is the SRPA and is supplied to the site through the INL raw water system. Containerized waste or monoliths will be placed and surrounded by soil waste and compacted by the same techniques.

For the purposes of waste compaction, waste may be placed in the landfill and grouted so that the void space surrounding and within certain waste types can be reduced, and the necessary compaction can be achieved. Additional details of the grouting operation are presented in Appendix A of the O\&M Plan (DOE-ID 2006b) and include grout compatibility with the waste, grouting setting, and waste types that may require grouting.

A compaction evaluation will be performed prior to waste being placed in the landfill. The objective of this compaction evaluation is to develop specific performance requirements necessary to obtain the required compaction of the waste. There are three types of soils that are generally encountered at INL. These include sands and gravels (alluvium), silt and sandy silt (topsoil), and silt and clay (old alluvium). Clean soils from the INTEC area will be used in this compaction evaluation, which will be performed in the temporary stockpile area near the landfill. Approximately $20 \mathrm{yd}^{3}$ of each soil type will be spread in a 1-ft-thick lift and then a dozer, similar to that proposed for compaction, will make one pass over the soil. After each pass, in-place density and moisture content will be measured to determine the relative compaction. The dozer will make repeated passes until the minimum compaction of $90 \%$ dry density, as determined by ASTM D698, is achieved. The number of passes for each soil type will be tracked during waste placement to ensure adequate compaction. Additional details of this compaction evaluation are included in Appendix A of the O\&M Plan.

In addition to the number of passes by equipment being tracked, compaction of the soil wastes will be verified by use of nuclear density field gauges or other comparable methods at a prescribed fill yardage frequency. The compaction test results will be entered into the operations log. The ICDF Complex operating log may be electronic or hardcopy, or a combination of media.

Additional information related to waste compaction and waste compaction testing in the ICDF landfill is provided in Section 4 and Appendix A of the O\&M Plan.

\subsubsection{Dust Control}

Dust control may be necessary during transportation, placement, and compaction to control wind dispersal of dust and contaminants from the landfill and active areas during operations and during off-hours. This will be accomplished by using water source at the dump face, water truck(s) and/or soil fixatives. Water will not be over-applied and field personnel will visually verify that no free liquid is present in the compacted waste mass. Fixatives recommended for use for dust control are provided in Appendix A of the O\&M Plan (DOE-ID 2006b). 
Additional information about landfill dust control is provided in Section 4 and Appendix A of the O\&M Plan.

\subsubsection{Radiological Survey Release from Landfill}

Following the completion of the waste off-loading, the radiological control technician will perform a radiological survey of each vehicle before it leaves the landfill. The tailgate area, rear of the vehicle, front tires, and the rear tires will be surveyed. If no contamination above background is detected, the vehicle will be released and will either return the empty container to the empty container staging area or leave the facility. If contamination is detected, the vehicle will be moved to a designated area and a more specific survey will be performed to identify the area of the contamination. Standard INL radiological decontamination procedures will be implemented to remove the contamination. The results of the radiological survey and decontamination process shall be recorded. Decontamination methods will start with dry decontamination. If wet decontamination techniques are necessary in the landfill, the equipment will be placed on an impervious surface or other similar system to capture decontamination fluids, or the equipment will be moved to the decontamination building for wet decontamination.

Additional information about radiological release of vehicles and containers from the ICDF landfill is provided in Sections 3 and 4, and Appendix A of the O\&M Plan (DOE-ID 2006b).

\subsection{Evaporation Pond Operations}

The ICDF evaporation pond consists of two individual cells; therefore, operations can take place in one cell while maintenance takes place in the other cell. The evaporation pond has been designated and constructed and will be operated as a CAMU in accordance with ARARs identified in the OU 3-13 ROD (DOE-ID 1999). The ICDF evaporation pond is designed to manage ICDF leachate and other aqueous waste types generated as a result of operating the ICDF Complex. It will also receive other WAG 3 aqueous waste types (e.g., purge, sampling, and well development water) that meet the ICDF evaporation pond WAC (DOE-ID 2006a). Liquid waste may be discharged into the evaporation ponds through two methods: (1) tank/truck unloading via the truck unloading station and (2) direct pumping.

A number of operational activities will be routinely conducted at the ICDF evaporation pond. The RA work elements described in this section include tanker off-loading, transfer of leachate to the evaporation pond from the ICDF landfill, transfer of ICDF Complex secondary waste from the decontamination building, transfer of decontamination water, washdown water, and purge/well development water, and evaporation pond washdown and freeboard.

Additional information related to ICDF evaporation pond operations is provided in Section 4 and Appendix A of the O\&M Plan (DOE-ID 2006b).

\subsubsection{Tanker Off-Loading}

Aqueous waste will be transferred directly to the ICDF evaporation pond, transferred to storage tanks, or possibly used in stabilization processes performed in the treatment unit as makeup water. Aqueous waste that does not meet the ICDF evaporation pond WAC (DOE-ID 2006a) will either be used in the treatment process or disposed of off-Site. Contaminants present in any aqueous waste used for treatment will be accounted for using the IWTS to ensure that operational limits are not exceeded.

A truck loading facility is provided outside the evaporation pond crest pad building for loading and unloading leachate/liquid to the evaporation pond. The concrete unloading pad at the truck loading facility is designed with curbs to prevent runoff. The pad is equipped with a riser and quick connect 
fitting designed to function in two modes, either as a discharge pipe (flow directed to the evaporation pond) or an intake pipe (flow directed to truck). Valve settings in the crest pad building may be adjusted depending on the desired mode. The pad itself is sloped to drain to an intermediate sump; liquid from the sump is pumped through the crest pad building to the evaporation pond.

Additional information related to tanker off-loading and the potential use of aqueous waste in the stabilization process is provided in Section 4 and Appendix A of the O\&M Plan (DOE-ID 2006b).

\subsubsection{Landfill Leachate}

Landfill leachate will be transferred from the landfill sumps (the leachate collection and recovery sump and both the Primary Leak Detection and Recovery System [PLDRS] and secondary leak detection and recovery system sumps) to the evaporation pond cells via the landfill crest pad building. Landfill leachate level in the sumps shall be monitored to ensure that continuous measuring, recording, and archiving of the leachate levels in the sumps and the volumes transferred from the leachate sump occurs. The records generated from the landfill leachate level shall be maintained electronically. The leachate transfer system for each sump is designed to operate in an automatic mode. Manual operation of all pumps is available by a hand switch. Valve alignment will be established for transfer to one of the cells of the evaporation pond. Sampling ports are installed on all leachate discharge lines in the landfill crest pad building. Sampling and analysis of landfill leachate will be performed by collecting samples from the Leachate Collection Recovery System (LCRS), as described in the Operational and Monitoring SAP (DOE-ID 2003d). Sump levels and volumes will be recorded and archived by the instrumentation and control system as well as recorded in the ICDF Complex operating log. The ICDF Complex operating log may be electronic or hardcopy, or a combination of media.

Weekly or monthly flow rates for the PLDRS converted to an average daily flow rate in gallons/acre/day also will be recorded in the ICDF Complex operating log. The ICDF Complex operating log may be electronic or hardcopy, or a combination of media. During operations, a weekly basis comparison will be made of the daily leak detection flow rate to the calculated action leakage rate (ALR). If the daily rate is equal or greater than the ALR, the process steps provided in Section 4 of the O\&M Plan (DOE-ID 2006b) will be implemented.

Additional information related to leachate collection and transfer to the evaporation pond is provided in Section 4 and Appendix A of the O\&M Plan.

\subsubsection{Aqueous Waste Transfer from the Decontamination Building}

Details of the process drain system for the SSSTF is provided in EDF-2648, "Process Systems Drain Pipe Sizing." Summary information regarding the transfer of these waste types to the ICDF evaporation pond is described below, with further information provided in Section 4 and Appendix A of the O\&M Plan (DOE-ID 2006b).

4.6.3.1 Decontamination Water, Washdown Water, and Purge Water. Decontamination building aqueous waste types will be transferred to the ICDF evaporation pond via the evaporation pond crest pad building. Decontamination building aqueous waste includes decontamination and washdown water generated from soil stabilization, debris treatment and processing, cleaning, and decontamination. Other aqueous waste, such as well development water that contains solids or an oil fraction, also will be transferred to the evaporation ponds from the decontamination building. Aqueous waste, regardless of source in the decontamination building, will pass through an oil/water separator and be collected in a pump station sump. 


\subsubsection{Leak Detection Water}

Leak detection water refers to water collected for the leak detection chambers of both evaporation pond cells and from the two systems at the landfill. Monitoring of the evaporation ponds is performed through the sacrificial geomembrane, primary geomembrane, and geosynthetic clay liners of the evaporation pond cells. The fluid levels in leak detection systems of the evaporation pond cells will be monitored and recorded. The ICDF Complex records may be electronic or hardcopy, or a combination of media. Liquid collected in the leak detection systems will be transferred to the evaporation ponds. If the ALR has been exceeded, the process steps provided in Section 4 of the O\&M Plan (DOE-ID 2006b) will be implemented

The leak detection transfer system for each sump is designed to operate in an automatic mode. Manual operation of both pumps, available by a hand switch, may be required to obtain a sample. Leak detection water will be sent to either the east or west evaporation pond depending on the valve alignment.

\subsubsection{Washdown and Freeboard}

Normal operations will have the evaporation pond crest pad building manifold valves adjusted to direct leachate flows into one of the evaporation pond cells. When one cell is filled, the other provides additional capacity, as well as serving as backup in case of leakage or damage in the first. The other waste sources are connected to the discharge piping through the manifold and will be conveyed to the same pond as the leachate. Check valves are provided on each line to prevent backflow and potential cross contamination.

As part of normal operation, levels in the evaporation pond must be maintained so that a minimum of $2 \mathrm{ft}$ of freeboard is available at all times. During normal operations, ponds will be maintained with water cover. Pond liners that are exposed with no water loads will be weighted with ballast tubes to prevent wind uplift from damaging the liner. Details can be found in EDF-ER-271, "Evaporation Pond Sizing with Water Balance and Make-up Water Calculations."

Supplemental water may be needed at the evaporation pond for dust control, for washing sediment to the bottom of the sump, and for maintaining submersion of the sediments at all times. The amount of water needed depends largely on weather conditions.

The pond was designed with a sloping bottom with a sump at the northern low point. Continually washing down the sediments to the sump area will reduce the overall need for supplemental water by reducing the surface area and hence the volume of water to keep the sediments submerged. In addition, the oil/water separator, concrete P-trap, and filtration for tanker off-loading will be used to minimize the sediment entering the evaporation pond.

\subsubsection{Aqueous Waste from WAG 3 Wells}

Aqueous wastewater from WAG 3 wells will be transported to the evaporation pond. The waste will be loaded at the well head, and a WTF will accompany the waste to the facility. The form will be checked at the ICDF Complex gate for completeness and accuracy. The volume of the waste will be recorded in gallons in lieu of weighing the load. Once the waste has been allowed through the gate, the driver will be directed to the evaporation pond. The truck or tank load will be discharged into the appropriate cell of the pond via the truck unloading pad. 


\subsection{Maintenance}

ICDF Complex maintenance will be performed to ensure components continue to function as designed. Equipment maintenance for the ICDF Complex will include preventative, predictive, and corrective maintenance to ensure safe and productive operations. An instrument calibration program will be part of the overall ICDF Complex maintenance program to ensure that instrument readings are correct to within a given tolerance. Equipment maintenance and instrument calibration is described in further detail in Section 6 of the O\&M Plan (DOE-ID 2006b).

Facility maintenance will be performed for the following:

- The ICDF Complex buildings

- The heating, ventilation, and air conditioning (HVAC) system in the ICDF Complex administration office trailer

- The radiant heating equipment in the decontamination and crest pad buildings

- Controls, instrumentation, and computer systems

- The wall-mounted air conditioners in the crest pad buildings

- Electrical systems, lighting systems, high-efficiency particulate air (HEPA) filtration systems in the decontamination building

- Treatment equipment, water systems, and sanitary sewer system

- Evaporation pond and landfill liner systems.

Facility maintenance activities include the following:

- Routine repairs to floors, windows, roofs, etc.

- Custodial services

- Winterization of all heaters/air conditioning systems and corresponding summer preparations

- Monthly operational checks of lighting systems (interior, exterior, and emergency systems)

- HEPA system inspection and servicing

- Periodic flow tests and inspections of the fire protection system

- Any necessary landfill or evaporation pond liner system repairs.

Additional information regarding facility maintenance is provided in Section 6 of the O\&M Plan.

Grounds and perimeter maintenance also will be performed for the ICDF Complex and include the following:

- Fence repair

- Repair of directional and other facility signs

- Weed and debris removal from stormwater ditches

- Vegetation and debris removal from around fences and buildings for fire prevention

- Housekeeping of storage areas and equipment pads 
- Snow removal from access routes, equipment pads, and storage areas

- Spreading of snow-melt or dry sand in pedestrian traffic areas.

\subsection{Environmental Compliance and Monitoring}

Environmental compliance and monitoring are ongoing operational work elements that will be performed as part of routine ICDF Complex operations. To ensure environmental compliance, the operation of the ICDF Complex will be conducted in accordance with the substantive requirements of the operations-related ARARs provided in Table 12-3 of the OU 3-13 ROD (DOE-ID 1999) for the ICDF Complex.

Table 3-8 in Section 3 of the O\&M Plan (DOE-ID 2006b) provides an environmental compliance table with the operations-related ARARs from the ROD. In addition to the ARAR citation, the table identifies the substantive monitoring or inspection requirements and/or substantive reporting or record requirements. Finally, the table also provides a reference to the ICDF Complex RAWP document or section that demonstrates the environmental compliance for each ARAR.

Environmental monitoring that will be conducted for the ICDF Complex includes sampling and analysis that will be conducted using four separate SAPs:

- Treated waste from batch treatment and treatability study samples will be sampled in accordance with the SSSTF Waste Stabilization Operations SAP (DOE-ID 2003c)

- Verification of all soil waste that is accepted for disposal in the ICDF landfill will be collected and analyzed in accordance with the ICDF Complex Waste Profile and Verification Sample Guidance (DOE-ID 2005)

- Groundwater will be sampled and analyzed in accordance with the ICDF Complex Groundwater Monitoring Plan (DOE-ID 2004)

- Routine ICDF Complex sampling and analysis of landfill leachate from the LCRS liquid from the PLDRS and SLDRS, evaporation pond water and sediments, and pump station liquid will be performed using the ICDF Complex Operational and Monitoring SAP (DOE-ID 2003d).

These sampling and analysis activities are further described in Section 3 of the O\&M Plan and also in the referenced SAPs.

\subsection{Closure}

When operations at the ICDF Complex cease, the ICDF Complex will be closed in accordance with the project ARARs identified in the OU 3-13 ROD (DOE-ID 1999). Section 9 of this RAWP provides details of closure activities that will be performed for the different components of the ICDF Complex. Additional closure information will be provided at the end of operations of the ICDF Complex. The current closure approach for the ICDF Complex is to clean-close all areas of the Complex except the landfill, which will be closed with an engineered cover, in accordance with the ARARs identified in the OU 3-13 ROD. 


\section{INSPECTIONS}

The following sections describe the inspections planned for the ICDF Complex. Inspections to be performed include Agency inspections, environmental inspections, and routine operations and maintenance inspections. The planned Agency inspections include a prefinal and final inspection of the ICDF Complex to verify that the ICDF Complex is ready to begin operations. As part of routine operation of the ICDF Complex, Complex operations personnel also will conduct numerous environmental, operations, and maintenance inspections.

In addition to the inspections outlined in the following sections, the Agency project managers or their designees may, at their discretion, inspect the site during the construction or operation phase of the ICDF Complex to assess compliance with the RA and the requirements outlined in the OU 3-13 ROD (DOE-ID 1999). These inspections may be conducted at any time during the ICDF Complex operation.

\subsection{Post-Construction Agency Inspections}

The post-construction Agency inspection process described in Remedial Design and Remedial Action Guidance for the Idaho National Engineering Laboratory (DOE-ID 1994) will be used for the ICDF Complex. The process is composed of a prefinal inspection, prefinal inspection report, and final inspection. Each of these activities for the ICDF Complex is described in detail in the following sections.

\subsubsection{Prefinal Inspection}

A prefinal inspection will be conducted by the Agency project managers at, or prior to, completion of the ICDF Complex construction. The draft Prefinal Inspection Checklist for the ICDF Complex, included in this RAWP as Table 5-1, will be further developed in cooperation with the Agencies or may be modified individually by each of the Agency representatives and will be used while conducting the inspection. The checklist encompasses the design, construction, and upcoming operational elements relevant to meeting the ROD (DOE-ID 1999) requirements, and identifies specific activities, procedures, or other items that constitute acceptance of the construction activities and readiness for operation of the ICDF Complex. The respective Agency representatives may include additional design, construction, or operational elements to their individual checklists to ensure the ICDF Complex is within the requirements of the FFA/CO (DOE-ID 1991). DOE Idaho will notify the Agencies approximately 2 weeks prior to the prefinal inspection date.

The Agency project managers will use their copies of the Prefinal Inspection Checklist to conduct the prefinal inspection. Several weeks preceding the prefinal inspection, the Agency project managers will re-evaluate the draft Prefinal Inspection Checklist and make any necessary changes in preparation for the inspection. The Prefinal Inspection Checklist may be modified individually by the Agencies prior to the inspection.

Although the draft Prefinal Inspection Checklist included in this document may be revised to add additional items for the inspection, this RAWP will not be revised to include the actual checklist used during the prefinal inspection. As described later in this document, the prefinal inspection checklist is a component of the RA Report, which will be submitted as a primary document. Each Agency representative's prefinal inspection checklist will be included in the RA Report.

The INL RD/RA Guidance (DOE-ID 1994) also indicates that a revision to the O\&M Plan (DOE-ID 2006b) would be submitted to the DEQ and EPA with the checklist, if applicable. An O\&M Plan revision would include updated operating and maintenance for the ICDF Complex. However, it is not anticipated that a revision to the ICDF Complex O\&M Plan will be necessary. 
Table 5-1. Draft ICDF Complex prefinal inspection checklist.

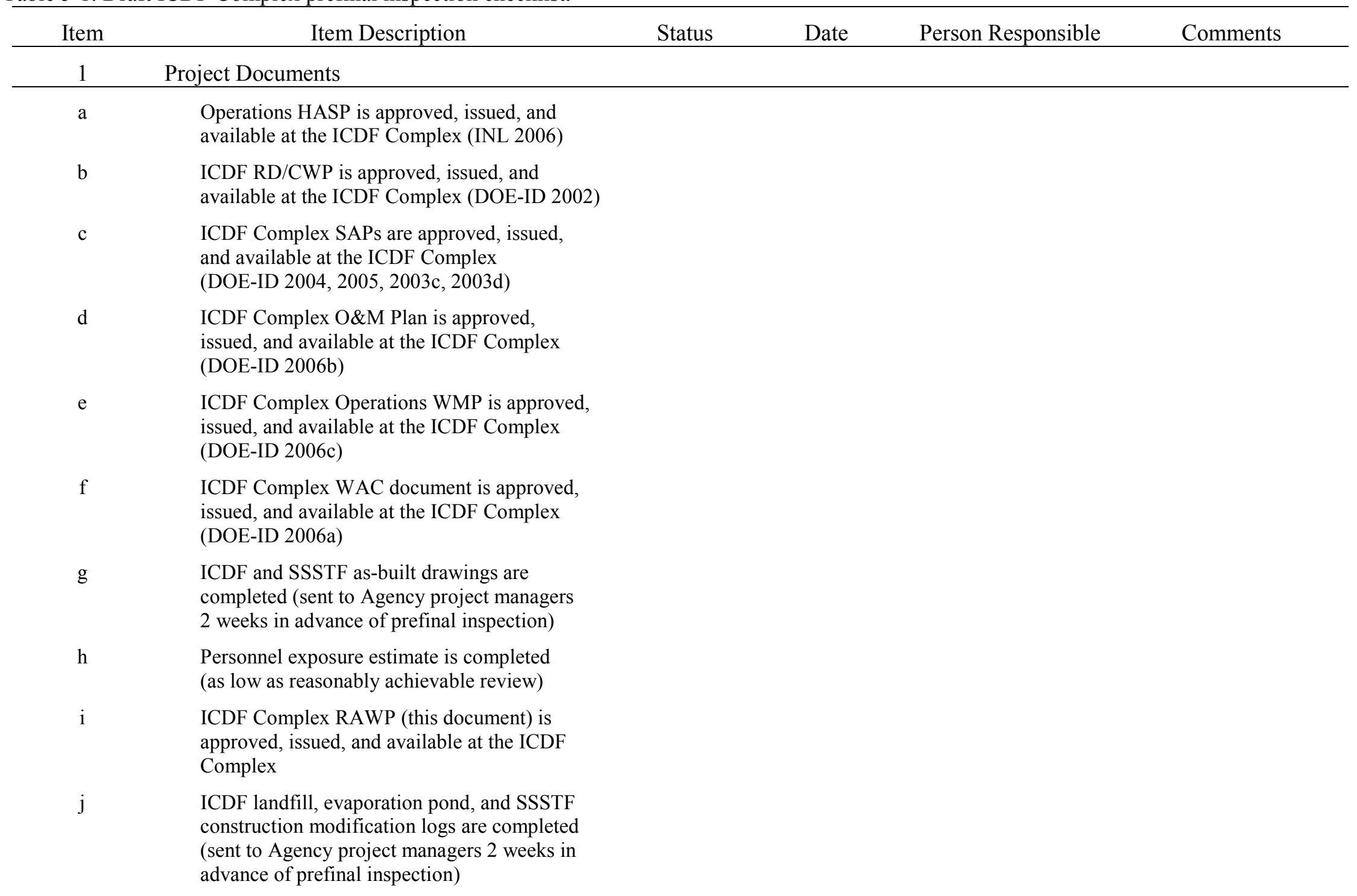


Table 5-1. (continued).

\begin{tabular}{|c|c|c|c|c|c|}
\hline Item & Item Description & Status & Date & Person Responsible & Comments \\
\hline $\mathrm{k}$ & $\begin{array}{l}\text { ICDF landfill, evaporation pond, and SSSTF } \\
\text { construction quality assurance and Title III } \\
\text { inspection reports are completed (sent to Agency } \\
\text { project managers } 2 \text { weeks in advance of prefinal } \\
\text { inspection) }\end{array}$ & & & & \\
\hline 2 & Procedures and Work Control Documents & & & & \\
\hline a & $\begin{array}{l}\text { Required Material Safety Data Sheets are } \\
\text { available }\end{array}$ & & & & \\
\hline $\mathrm{b}$ & Emergency notification list is posted & & & & \\
\hline $\mathrm{c}$ & Inspection procedures are issued & & & & \\
\hline $\mathrm{d}$ & Institutional controls are in place & & & & \\
\hline $\mathrm{e}$ & Inspection requirements have been established & & & & \\
\hline$f$ & $\begin{array}{l}\text { Operation and maintenance procedures are } \\
\text { issued }\end{array}$ & & & & \\
\hline g & $\begin{array}{l}\text { Waste loading and transportation procedures are } \\
\text { issued }\end{array}$ & & & & \\
\hline $\mathrm{h}$ & Logkeeping procedures are issued & & & & \\
\hline $\mathrm{i}$ & Access control procedures are issued & & & & \\
\hline $\mathrm{j}$ & Leakage and spill response procedures are issued & & & & \\
\hline $\mathrm{k}$ & $\begin{array}{l}\text { Action leakage rates (ALRs) have been } \\
\text { established and responses to exceedances } \\
\text { have been defined }\end{array}$ & & & & \\
\hline
\end{tabular}

a All ICDF Complex personnel have been identified and are available

b Training requirements have been identified for ICDF Complex personnel 
Table 5-1. (continued).

\begin{tabular}{|c|c|c|c|c|c|}
\hline Item & Item Description & Status & Date & Person Responsible & Comments \\
\hline \multirow[t]{9}{*}{$\mathrm{c}$} & $\begin{array}{l}\text { ICDF Complex personnel have been trained to } \\
\text { requirements identified in the HASP (INL 2006), } \\
\text { and the training is documented }\end{array}$ & & & & \\
\hline & $\begin{array}{l}\text { Occupational Safety and Health } \\
\text { Administration (OSHA) } 29 \text { CFR 1910.120 } \\
\text { 40-hr "Hazardous Waste Operations and } \\
\text { Emergency Response" (HAZWOPER) }\end{array}$ & & & & \\
\hline & OSHA 29 CFR 1910.120 8-hr supervisor & & & & \\
\hline & First aid/CPR & & & & \\
\hline & Radiological Worker II & & & & \\
\hline & Site HASP & & & & \\
\hline & Lockout/tagout training & & & & \\
\hline & Operations procedures & & & & \\
\hline & Logkeeping & & & & \\
\hline $\mathrm{d}$ & $\begin{array}{l}\text { RCRA emergency coordinators are trained and } \\
\text { on-Site }\end{array}$ & & & & \\
\hline 4 & Equipment and System Readiness & & & & \\
\hline a & $\begin{array}{l}\text { Liner testing and certification has been } \\
\text { completed and documented }\end{array}$ & & & & \\
\hline $\mathrm{b}$ & $\begin{array}{l}\text { Leachate collection and transfer system has been } \\
\text { tested and deficiencies corrected }\end{array}$ & & & & \\
\hline $\mathrm{c}$ & $\begin{array}{l}\text { SSSTF systems (scales, administration facilities, } \\
\text { computer hookups, waste tracking system, alarm } \\
\text { systems) have been tested and deficiencies } \\
\text { corrected (turnover complete) }\end{array}$ & & & & \\
\hline $\mathrm{d}$ & $\begin{array}{l}\text { Certification is on file from a qualified engineer } \\
\text { that dikes have structural integrity }\end{array}$ & & & & \\
\hline
\end{tabular}


Table 5-1. (continued).

\begin{tabular}{|c|c|c|c|c|c|}
\hline Item & Item Description & Status & Date & Person Responsible & Comments \\
\hline e & $\begin{array}{l}\text { Personal protection equipment is identified and } \\
\text { available }\end{array}$ & & & & \\
\hline $\mathrm{f}$ & $\begin{array}{l}\text { Medical and first aid supplies are identified and } \\
\text { available }\end{array}$ & & & & \\
\hline $\mathrm{g}$ & $\begin{array}{l}\text { Walk-down and visual verification that the } \\
\text { operating systems in the decontamination } \\
\text { building and crest pad buildings are in working } \\
\text { order }\end{array}$ & & & & \\
\hline $\mathrm{h}$ & $\begin{array}{l}\text { Fire protection equipment is identified and } \\
\text { available }\end{array}$ & & & & \\
\hline $\mathrm{i}$ & $\begin{array}{l}\text { Recommended spare parts from Appendix B } \\
\text { of the O\&M Plan (DOE-ID 2006b) are readily } \\
\text { available at INL in order to not impede } \\
\text { operations }\end{array}$ & & & & \\
\hline $\mathrm{j}$ & $\begin{array}{l}\text { Critical spare parts are identified with an } \\
\text { identified storage location }\end{array}$ & & & & \\
\hline $\mathrm{k}$ & All components have been appropriately labeled & & & & \\
\hline 1 & $\begin{array}{l}\text { All applicable radiological signs and barriers in } \\
\text { place }\end{array}$ & & & & \\
\hline $\mathrm{m}$ & All applicable traffic control signs in place & & & & \\
\hline $\mathrm{n}$ & $\begin{array}{l}\text { All applicable perimeter fences, gates, locks, and } \\
\text { signs in place }\end{array}$ & & & & \\
\hline 5 & Operation of Safety Systems & & & & \\
\hline $\mathrm{a}$ & $\begin{array}{l}\text { System shutdown mechanisms have been } \\
\text { satisfactorily tested }\end{array}$ & & & & \\
\hline $\mathrm{b}$ & $\begin{array}{l}\text { Operational limits have been established and } \\
\text { tested }\end{array}$ & & & & \\
\hline
\end{tabular}


Table 5-1. (continued).

\begin{tabular}{|c|c|c|c|c|c|}
\hline Item & Item Description & Status & Date & Person Responsible & Comments \\
\hline 6 & Management Programs & & & & \\
\hline a & $\begin{array}{l}\text { Personnel responsibilities and line of authority } \\
\text { are clearly defined }\end{array}$ & & & & \\
\hline $\mathrm{b}$ & $\begin{array}{l}\text { Primary and secondary emergency evacuation } \\
\text { routes posted }\end{array}$ & & & & \\
\hline $\mathrm{c}$ & Management self-assessment completed & & & & \\
\hline 7 & Routine and Emergency Operations Program & & & & \\
\hline a & $\begin{array}{l}\text { System shutdown notification system is in place } \\
\text { and has been tested for proper operation }\end{array}$ & & & & \\
\hline $\mathrm{b}$ & $\begin{array}{l}\text { Abnormal conditions procedures have been } \\
\text { approved and issued }\end{array}$ & & & & \\
\hline $\mathrm{c}$ & $\begin{array}{l}\text { Security surveillance and notification } \\
\text { requirements have been established with the } \\
\text { facility security organization }\end{array}$ & & & & \\
\hline $\mathrm{d}$ & $\begin{array}{l}\text { Voice paging and emergency systems have } \\
\text { been tested. }\end{array}$ & & & & \\
\hline
\end{tabular}


As the prefinal inspection is performed, issues that are identified will be noted. The outstanding items noted during the inspection will be resolved at the completion of the prefinal inspection, or a Corrective Action Plan will be developed. All of the deficiencies and outstanding items, along with the actions required to resolve them, will be identified and approved by the Agency project managers during the prefinal inspection. The Corrective Action Plan will then document any unresolved items and the action(s) required to resolve them. A date for the final inspection will be scheduled at the completion of the prefinal inspection, if the Agency project managers deem a final inspection necessary. Potentially, if the prefinal inspection did not identify any outstanding items, or if the status of the remaining issues can be completed to the satisfaction of the Agency project managers without a final inspection, there may be no need for a final inspection.

\subsubsection{Prefinal Inspection Report}

Following the prefinal inspection, the Prefinal Inspection Report will be prepared and submitted to the Agencies as a secondary document. Although DOE Idaho responds to comments received from EPA and DEQ, the Prefinal Inspection Report is not revised or resubmitted. The comments are resolved in the Final Inspection Report, which is included in the draft RA Report, a primary document, in accordance with Section 8.4 of the FFA/CO (DOE-ID 1991). Each of the Agency representative's prefinal inspection checklists is included in the Prefinal Inspection Report. All of the deficiencies and outstanding items identified by each Agency representative's prefinal inspection checklist, along with the actions taken to resolve the deficiencies, are documented in the Prefinal Inspection Report, which will include the following:

- Names of inspection participants

- Completed inspection checklist from each Agency representative identifying deficiencies and/or outstanding RA requirements

- Outstanding construction requirements

- Corrective action required to resolve identified items

- Schedule for completion of corrective actions

- Final inspection activities

- Date of final inspection.

\subsubsection{Final Inspection}

The ICDF Complex final inspection is conducted following a period of operations succeeding startup; this period is known as the shakedown period. Some equipment may remain on-Site to repair items observed during the final inspection. The final inspection, conducted by the Agency project managers, confirms the resolution of all outstanding items identified in the prefinal inspection, marks the closure of the shakedown period, and verifies that the ICDF Complex has been constructed and is operating in accordance with the requirements of the ROD (DOE-ID 1999), the Corrective Action Plan developed from the prefinal inspection, and this RAWP. Section 6.

The Final Inspection Report will be included as an element of the RA Report, described in 


\subsection{Environmental, Operation, and Maintenance Inspections}

Routine operations and maintenance inspections will be performed for various components of the ICDF Complex. These inspections are described in Section 8 of the O\&M Plan (DOE-ID 2006b).

Table 5-2 provides a summary of the inspections that will be performed, including the frequency and the purpose of the inspection, categorized by ICDF Complex, landfill, evaporation pond, waste storage, decontamination building, miscellaneous unit, and tank inspections.

For the purposes of O\&M inspections, a significant storm event and severe erosion are defined in Section 8 of the O\&M Plan. The effectiveness of dust suppression is a relative inspection item that will be evaluated based upon minimized visible dust in the air. Section 8.7 of the O\&M Plan discusses corrective actions for deficiencies identified during inspections.

Table 5-2. ICDF Complex routine operations and maintenance inspections.

\begin{tabular}{|c|c|c|}
\hline Inspection Name & $\begin{array}{l}\text { Inspection } \\
\text { Frequency }^{\mathrm{a}}\end{array}$ & Inspection Purpose \\
\hline \multicolumn{3}{|l|}{ ICDF Complex Inspections } \\
\hline ICDF Complex fences & Weekly & $\begin{array}{l}\text { Ensure fences are in good condition, no buildup of } \\
\text { windblown material, gates are functional and closed } \\
\text { when not in use, locks are in working order, and } \\
\text { perimeter warning signs are properly placed and in } \\
\text { good condition }\end{array}$ \\
\hline $\begin{array}{l}\text { ICDF Complex access and } \\
\text { haul roads }\end{array}$ & $\begin{array}{l}\text { Following each } \\
\text { significant storm } \\
\text { event }\end{array}$ & $\begin{array}{l}\text { Ensure adequate drainage, identify evidence of severe } \\
\text { erosion, identify evidence of spills, ensure roads are in } \\
\text { a condition to allow safe operation }\end{array}$ \\
\hline $\begin{array}{l}\text { ICDF Complex stormwater } \\
\text { runoff control ditches }\end{array}$ & Weekly & $\begin{array}{l}\text { Ensure ditches and culverts are free of obstructions, } \\
\text { that drainage is not impeded, runoff is being directed } \\
\text { to the intended areas, and identify evidence of } \\
\text { overflow from ditches }\end{array}$ \\
\hline $\begin{array}{l}\text { ICDF Complex dust } \\
\text { suppression }\end{array}$ & Each operating day & Evaluate effectiveness of dust suppression controls \\
\hline $\begin{array}{l}\text { ICDF Complex animal } \\
\text { intrusion }\end{array}$ & Weekly & $\begin{array}{l}\text { Inspect for animal intrusion (tracks, burrowing) within } \\
\text { the ICDF Complex }\end{array}$ \\
\hline
\end{tabular}

Landfill Inspections

Landfill general inspections

(40 CFR 264.303;

40 CFR 264.15[a])
Weekly

(1)
Identify malfunctions and deterioration, improper operation of run-on/run-off control systems, and presence of leachate in the collection and removal systems; also, ensure proper functioning of the leachate collection and removal systems, as defined in Appendix A of the O\&M Plan (DOE-ID 2006b).

Inspect level transducer to ensure it is operational so that the depth of leachate does not exceed $1 \mathrm{ft}$ in the sump

Identify operator errors and discharges that may lead to the release of hazardous constituents or threat to human health

Inspect for animal intrusion (tracks, burrowing) at the landfill and landfill crest pad building 
Table 5-2. (continued).

\begin{tabular}{|c|c|c|}
\hline Inspection Name & $\begin{array}{l}\text { Inspection } \\
\text { Frequency }^{\mathrm{a}}\end{array}$ & Inspection Purpose \\
\hline Benchmarks & Annually & Ensure permanence \\
\hline ICDF landfill crest pad building & $\begin{array}{l}\text { See Appendix A } \\
\text { of the O\&M Plan }\end{array}$ & $\begin{array}{l}\text { Inspections including, but not limited to, structural } \\
\text { elements, HVAC, sumps, pumps, alarm systems, } \\
\text { instrumentation, and mechanical systems to ensure } \\
\text { correct operation of these components }\end{array}$ \\
\hline
\end{tabular}

Evaporation Pond Inspections

Evaporation pond general inspections

(40 CFR 264.15[a] and

40 CFR 264.226[b][1,2,3])

Evaporation pond crest pad building
Weekly

Identify malfunctions and deterioration, improper operation of overtopping control systems, water level fluctuations, severe erosion or other signs of deterioration of dikes and other containment devices, discharges that may lead to the release of hazardous constituents or threat to human health, as defined in Appendix A of the O\&M Plan, and record the water level of both ponds (40 CFR 264.226[d][1]).

Inspect and record the water level of both pond cells; ensure that minimum freeboard of two $\mathrm{ft}$ is being maintained and that sandbag system is intact

Evidence of liner wind lift in empty areas

Inspect for animal intrusion (tracks, burrowing) at the evaporation pond and evaporation pond crest pad building

Inspect for visible damage to the evaporation pond HDPE liners and inspect for unusual foreign debris in the pond cells

See Appendix A of the O\&M Plan
Inspections including, but not limited to, structural elements, HVAC, sumps, pumps, alarm systems, instrumentation, and mechanical systems to ensure correct operation of these components

\footnotetext{
Waste Staging and Storage Inspections
}

Area management

Weekly

Spills and leaks

Weekly

Containment

Weekly
Ensure that adequate aisle space exists for personnel and equipment to respond to emergencies and/or conduct inspections, that wastes are segregated for compatibility, that quantities and containers recorded in the logbook equal the quantities and containers stored in the waste staging or storage area, and that waste streams do not exceed 2 years of staging

Identify evidence of leaking and deterioration of containers and integrity of pads

Ensure that containers storing liquid have adequate secondary containment, that dikes or berms used for secondary containment restrict run-on precipitation from entering storage areas, that tarps over soil piles are secure and runoff is being appropriately directed, and that liners under soil piles are functioning to isolate the pile 
Table 5-2. (continued).

\begin{tabular}{|c|c|c|}
\hline Inspection Name & $\begin{array}{l}\text { Inspection } \\
\text { Frequency }^{\mathrm{a}}\end{array}$ & Inspection Purpose \\
\hline Labeling & Weekly & $\begin{array}{l}\text { Ensure that all containers and bulk soil are properly } \\
\text { labeled or have signs, and that labels/signs and marks } \\
\text { are visible to the inspector }\end{array}$ \\
\hline Containers & Weekly & Inspect containers for leakage and deterioration \\
\hline \multicolumn{3}{|l|}{ (40 CFR 264.173) } \\
\hline Emergency response & Weekly & $\begin{array}{l}\text { Ensure that emergency procedures as defined in the } \\
\text { HASP are present (INL 2006) }\end{array}$ \\
\hline \multicolumn{3}{|l|}{ Decontamination Building Inspections } \\
\hline \multirow[t]{3}{*}{$\begin{array}{l}\text { Building (containment building) } \\
\text { (40 CFR 264.1101[c][4]) }\end{array}$} & \multirow[t]{3}{*}{ Weekly } & $\begin{array}{l}\text { Inspect and record data gathered from monitoring } \\
\text { equipment, treatment equipment, lift station sumps } \\
\text { and pumps, and leak detection equipment to detect } \\
\text { signs of releases of hazardous waste, as defined in } \\
\text { Appendix A of the O\&M Plan }\end{array}$ \\
\hline & & $\begin{array}{l}\text { Inspect containment building and area immediately } \\
\text { surrounding the containment building to detect signs } \\
\text { of releases of hazardous waste }\end{array}$ \\
\hline & & $\begin{array}{l}\text { Ensure structural components, utilities, alarm systems, } \\
\text { and instrumentation function as designed }\end{array}$ \\
\hline \multicolumn{3}{|l|}{ Tank Inspections } \\
\hline \multirow[t]{2}{*}{$\begin{array}{l}\text { ICDF Complex tanks } \\
\text { (40 CFR 264.195[b]) }\end{array}$} & \multirow[t]{2}{*}{ Daily } & $\begin{array}{l}\text { Detect corrosion or releases of waste, ensure } \\
\text { overfill/spill control equipment is in good working } \\
\text { order, and ensure the monitoring and leak detection } \\
\text { equipment for the tank system is being operated } \\
\text { according to its design, as defined in Appendix A of } \\
\text { the O\&M Plan }\end{array}$ \\
\hline & & $\begin{array}{l}\text { Detect erosion or signs of releases of hazardous waste } \\
\text { by inspecting the construction materials and the area } \\
\text { immediately surrounding the external accessible } \\
\text { portions of the tank system, including the secondary } \\
\text { containment system }\end{array}$ \\
\hline
\end{tabular}

a. In addition to the inspection frequency provided in this table, inspections also will be performed following a significant rain, snow, windstorm, or other event that may impact the safe operation of the ICDF Complex.

HASP $=$ health and safety plan

HDPE $=$ high-density polyethylene

HVAC $=$ heating, ventilating, and air conditioning

$\mathrm{O} \& \mathrm{M}=$ operations and maintenance 


\section{REPORTING AND RECORDKEEPING}

This section provides the plan for ICDF Complex reporting and recordkeeping, in compliance with the OU 3-13 ROD (DOE-ID 1999) and the required elements contained as part of this RAWP. Types of reports that are discussed include annual ICDF Complex reports (described in Section 6.1), the ICDF Complex RA Report (described in Section 6.2), and 5-year reviews (described in Section 6.3).

Recordkeeping is presented in Section 6.4, with additional detail provided in Section 10 of the O\&M Plan (DOE-ID 2006b).

\subsection{ICDF Complex Annual Reports}

During the operational, closure, and postclosure periods of the ICDF Complex, the results of the ICDF Complex groundwater monitoring will be documented in an annual report to DEQ and EPA. The annual reports will discuss methods selected and associated background limits established for each parameter, results of any resampling, impacts of seasonal and spatial variability, and any temporal trends found. The first annual report was prepared after the ICDF Complex became operational and the initial year of sampling results were validated and evaluated. Subsequent annual reports will incorporate each additional year of sampling results.

The ICDF Complex annual groundwater monitoring report will include the following information:

- A summary of sampling activities, which provides a listing of dates when samples were collected from the groundwater monitoring wells and when leachate samples were collected

- An updated water table map for each routine monitoring event

- A table indicating the water level measurements

- A summary of analytical results for the year

- Leachate monitoring results, which include a summary of leachate analyses from recent sampling and leachate volumes generated.

The annual report will include a statistical analysis of the monitoring data that has been gathered. Several requirements for the selected statistical method are presented in 40 CFR 264.97, "General Ground-water Monitoring Requirements," and discussed in relation to the ICDF Complex in the INEEL CERCLA Disposal Facility Groundwater Detection Monitoring Program: Data Analysis Plan (DOE-ID 2003a). The statistical test chosen will be conducted separately for each hazardous constituent in each well. Use of either statistical method will be protective of human health and the environment and must comply with performance standards.

Groundwater monitoring data collected in accordance with 40 CFR 264.97(g), including actual levels of constituents, will be maintained in the facility operating records.

In addition to submitting an annual groundwater report to the Agencies, DOE Idaho will include the ICDF Complex in the INL Annual NESHAP Report and the INL annual IDAPA emissions report.

\subsection{Remedial Action Report}

The RA Report will be prepared following completion of the ICDF Complex construction and the prefinal and final inspection process, and submitted to the Agencies as a primary document. In accordance with the FFA/CO (DOE-ID 1991), the draft ICDF Complex RA Report will be submitted 
within 60 days of the final inspection. The ICDF Complex RA Report, based upon the FFA/CO and the INL RD/RA Guidance (DOE-ID 1994), will include the following:

- A synopsis of the construction work defined in the ICDF RD/CWP (DOE-ID 2002) and certifications that this work was performed.

- Any modifications made to the RD during the ICDF Complex construction phase, including the purpose of performed modifications and results of modifications.

- Problems encountered during the ICDF Complex construction and resolutions to these problems.

- Explanation of any modifications to this RAWP.

- Discussion of any outstanding items from the prefinal inspection that were identified and described, along with the Corrective Action Plan to resolve the outstanding items.

- Responses to comments received from the Prefinal Inspection Report and incorporation/resolution of those comments.

- Discussion of final inspection results.

- Results of the initial shakedown, including observations and corrective actions taken. Results of the initial operation period that occurs after shakedown and prior to submittal of the RA Report also will be included.

- O\&M Plan update, if necessary. An O\&M Plan update will include all information currently provided in the O\&M Plan (DOE-ID 2006b), plus information obtained from the initial operating period prior to submittal of the RA Report.

- As-built drawings showing final contours and final configurations for all components of the ICDF Complex.

- Final total costs for this portion of the RA and an updated cost estimate for future operational expenditures.

- Deadline and target dates for submission of new deliverables, if any are identified.

- Certification that the remedy is operational and functional.

\subsection{Five-Year Review}

The "National Oil and Hazardous Substances Pollution Contingency Plan" (40 CFR 300), commonly referred to as the National Contingency Plan, requires that RAs that result in any hazardous substances, pollutants, or contaminants remaining at the site above levels that allow for unlimited use and unrestricted exposure be reviewed every 5 years to ensure protection of human health and the environment. The 5-year reviews evaluate the remedy to determine whether it continues to be protective.

The plan for 5-year reviews at the ICDF Complex has been developed using EPA's Comprehensive Five-Year Review Guidance (EPA 2001), which was developed to promote consistent implementation of the 5-year review process. 
The ICDF landfill is designed to serve as a centralized, engineered disposal facility for all INL CERCLA wastes that meet the ICDF landfill WAC (DOE-ID 2006a). As such, the ICDF landfill will have hazardous substances, pollutants, or contaminants remaining above levels that allow for unlimited use and unrestricted exposure. Therefore, the ICDF landfill will be subject to 5-year reviews for an indefinite period of time so that the landfill portion of the remedy can be reviewed every 5 years to ensure protection of human health and the environment. Five-year reviews for the ICDF landfill would be considered statutory reviews based upon definitions provided in EPA Five-Year Review Guidance (EPA 2001).

The ICDF evaporation pond and support facilities (e.g., decontamination building, waste storage areas, and crest pad buildings) are designed to contain, control, or monitor hazardous substances above levels that allow for unlimited use and unrestricted exposure. Therefore, the ICDF evaporation pond and support facilities will be part of the 5-year review. However, as these components of the remedy are planned to eventually be clean closed, the 5-year review process for these portions of the remedy will no longer be conducted when hazardous substances, pollutants, or contaminants are reduced to levels that allow for unlimited use and unrestricted exposure. The cessation of 5-year reviews for these components of the ICDF Complex will be documented in a 5-year review report, when the review concludes that these areas no longer contain contaminants above unacceptable levels. It should be noted, however, that if restrictions of land and/or groundwater use by humans and/or ecological populations (institutional controls) are necessary for these areas, then the use has been limited and a 5-year review will be conducted. Five-year reviews would be defined as statutory for the ICDF evaporation pond and support facilities, according to EPA Five-Year Review Guidance (EPA 2001), as long as institutional controls remain in place for these remedy components.

Currently, it is planned that all portions of OU 3-13 will be evaluated in a single periodic 5-year review. Five-year reviews will note any changes in the physical configuration of the area and will determine whether OU 3-13 can continue to achieve the remediation goals outlined in the OU 3-13 ROD (DOE-ID 1999). As part of the review process, the Agencies will review the protectiveness of the ROD remedy decisions and adjust to updates in public protectiveness levels, new applicable regulations, or updated action levels.

The first OU 3-13 5-year review was completed within 5 years of the start of continuous RA for OU 3-13, which occurred in year 2000. Therefore, the first OU 3-13 5-year review was completed through all levels of review by year 2005. As a matter of policy, subsequent 5 -year reviews should be completed no less often than every 5 years, but may be completed more frequently if necessary to evaluate the protectiveness of human health and the environment (EPA 2001).

Each 5-year review for OU 3-13 should include the status and protectiveness determination of the 5-year reviews conducted for the other areas of the entire Site. The subdivision of OU 3-13 into separate 5-year reviews will not review any site within OU 3-13 later than 5 years after the start of continuous RA for that site.

The Five-Year Review Report will be prepared and submitted as a primary document to EPA and DEQ for review and comment. In accordance with 42 USC § 9620, "Comprehensive Environmental Response, Compensation and Liability Act of 1980," and Executive Order 12580, "Superfund Implementation," once EPA and DEQ have concurred with the report, copies of the final Five-Year Review Report will be provided to EPA Headquarters, DEQ, and site information repositories within 10 days of signature (EPA 2001). 
The 5-year review for OU 3-13 will be conducted using EPA's Comprehensive Five-Year Review Guidance as a handbook for executing the review (EPA 2001). Sections 3 and 4 of the guidance provide assistance to prepare for, conduct, and assess protectiveness as part of the review. Additional OU 3-13 specific guidance may be developed collectively by the Agencies to assist with the 5 -year review process to assess remedy protectiveness. Items to be reviewed during the first 5-year review will include, at a minimum, the following:

- Inspection to determine the condition of access controls (i.e., signs, postings, markers, and fences)

- Inspection of any reseeded or reclaimed areas to determine viability

- Visual inspection of exposed evaporation pond high-density polyethylene (HDPE) liner material

- Review of the ICDF landfill and evaporation pond leak detection data

- Review of leachate generation volumes, characterization data, and leachate management

- Review of run-on and run-off controls

- Evaluation of groundwater monitoring data.

\subsection{Recordkeeping}

Recordkeeping for the ICDF Complex operations is designed to effectively process and maintain records as required by ARARs, in accordance with INL company procedures.

The ICDF Complex records coordinator will process all project records. This ensures that records are processed methodically and uniformly. The records coordinator will also verify that all records are complete before they are submitted to INL's Document Control, Administrative Record and Information Repository, and/or the Electronic Document Management/Optical Imaging System (EDM/OIS). In addition, the records coordinator will verify required record retention periods and will ensure records are available for inspections, reviews, and other requests as necessary. Figure 6-1 illustrates the project records management process.

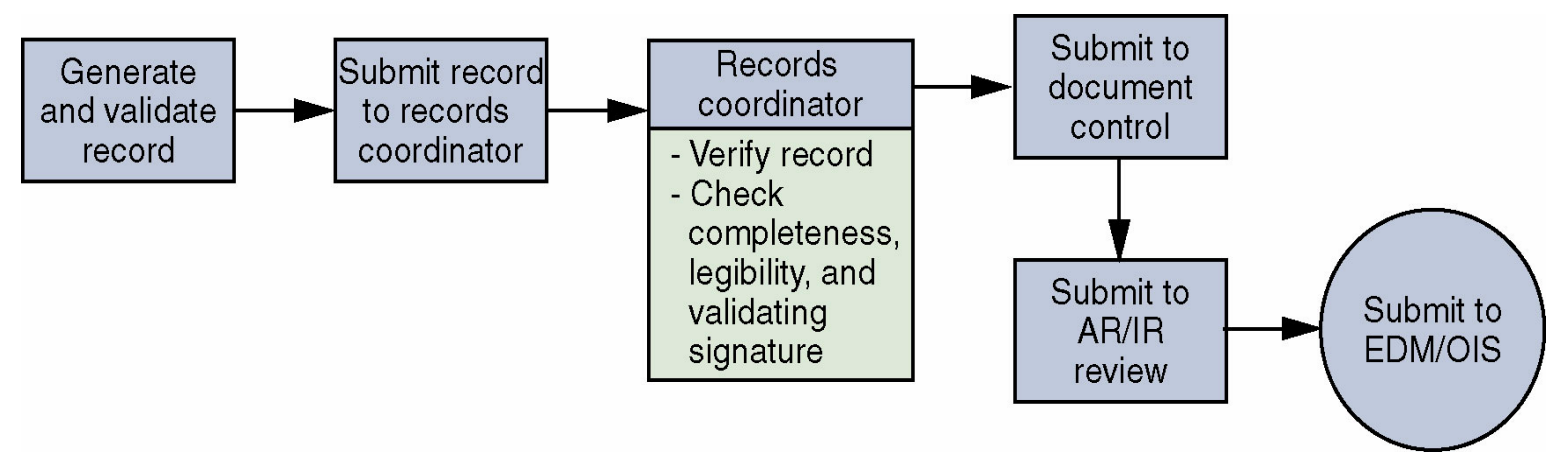

Figure 6-1. Records management process for the ICDF Complex.

ICDF Complex project records will be readily accessible. The project's record copies will be stored electronically in the EDM/OIS. This system implements the requirements of the FFA/CO (DOE-ID 1991) and INL policies for records management and provides a long-term stewardship baseline.

Section 10 of the ICDF Complex O\&M Plan (DOE-ID 2006b) provides additional information regarding recordkeeping for the ICDF Complex. 


\section{HEALTH AND SAFETY/EMERGENCY RESPONSE}

The ICDF Complex HASP (INL 2006) identifies health, safety, and radiological hazards associated with ICDF Complex operations and specifies the programmatic requirements and implementing procedures used to control or minimize these hazards. ICDF Complex engineering controls, hazard isolation, specialized work practices, and the use of personal protective equipment (PPE) will all be implemented to eliminate or mitigate potential operational hazards and personnel exposures where feasible. The ICDF Complex HASP will be used in conjunction with safety and health policies and procedures to provide a systematic approach to recognize, evaluate, and control ICDF Complex hazards and meet the requirements of 29 CFR 1910.120, "Hazardous Waste Operations and Emergency Response" (HAZWOPER).

The ICDF Complex HASP provides a systematic analysis of ICDF Complex operations, associated hazards, and controls. The HASP includes the following key sections:

- ICDF Complex work scope

- Hazard identification and mitigation

- Exposure monitoring and sampling

- Accident and exposure prevention

- PPE

- Personnel training

- Site control and security

- Occupational medical surveillance

- ICDF Complex personnel roles and responsibilities

- Emergency Response Plan

- Decontamination procedures

- Recordkeeping

- Pre-emergency planning.

The ICDF Complex HASP will be supplemented with ICDF Complex-specific operational job safety analyses, technical procedures, and standardized safety forms. These facility-specific documents will be used to further define ICDF Complex operational hazards, controls, and procedural requirements for ensuring safe ICDF Complex operational practices. The ICDF Complex-assigned safety, health, and radiological professionals will develop this documentation and continually evaluate hazard control and mitigation measures. Operational work control documents will be updated when new hazards are introduced or encountered to maintain the highest degree of safety during facility operations.

Idaho National Laboratory requirements will be incorporated into all ICDF Complex operational activities and tasks and serve as the foundation for implementation of Integrated Safety Management System at the ICDF (as detailed in Section 4 of the HASP).

Finally, the HASP Emergency Response Plan (detailed in Section 10 of the HASP) has been prepared in accordance with 29 CFR 1910.120 (HAZWOPER) requirements to provide detailed information on the response and protective actions that ICDF Complex personnel will take in the event 
of an emergency at the ICDF Complex or other INL facility. This section includes information on the following emergency response items:

- Pre-emergency planning

- Emergency preparation and recognition

- Emergency facilities and equipment

- Emergency communications (and notifications)

- Personnel roles, lines of authority, and training (including spill response and personnel accountability)

- Emergency alerting, responses, and sheltering

- Evacuation assembling areas and medical facilities (including maps)

- Medical and emergency decontamination

- Reentry, recovery, and site control

- Critique of response and follow-up

- Emergency contact information.

The HASP Emergency Response Plan references the existing INL emergency response organization, equipment, facilities, and standardized alarms and signals. The "INEEL Emergency Plan RCRA Contingency Plan" (PLN-114), INTEC supplement to PLN-114 (Addendum 2), and emergency action manager roles and responsibilities are fully integrated with the ICDF Complex HASP Emergency Response Plan.

The ICDF Complex HASP will be evaluated and updated as deemed appropriate by ICDF Complex assigned health, safety, and radiological professionals to ensure that hazards from new ICDF Complex operations, equipment, and processes are addressed in the HASP and other appropriate ICDF Complex work controls. 


\section{WASTE MANAGEMENT PLAN}

Wastes generated from ICDF Complex operations will be managed on-Site as CERCLA waste in accordance with the ICDF Complex Operations Waste Management Plan (WMP) (DOE-ID 2006c). The WMP addresses waste management issues associated with the generation of waste from operations of the ICDF Complex only. Waste generated as a result of ICDF Complex operations will be managed in accordance with specific criteria in the ICDF Complex WAC document (DOE-ID 2006a), depending upon the disposition of the operations-generated waste (i.e., evaporation pond, landfill, SSSTF). 


\section{CLOSURE AND POSTCLOSURE REQUIREMENTS}

Beginning in the last year of waste placement in the landfill, and assuming no future use of the facilities, the ICDF landfill, evaporation pond with two cells, decontamination building, waste staging areas, and ancillary facilities will be closed. The decontamination building will be closed first so that contaminated decontamination building materials and debris can be placed in the landfill. The landfill will be the second facility closed. At some time following closure of the landfill, or completion of the postclosure period, the evaporation pond will be closed; each cell of the evaporation pond may be closed separately. It is the goal of DOE Idaho to close all associated ICDF Complex units under a clean closure, with the exception of the ICDF landfill. These closure activities will be conducted in accordance with ARARs identified in the ROD (DOE-ID 1999) and as described in the ARAR compliance strategy included with the Technical and Functional Requirements (TFR-71; TFR-17). Additional closure information will be provided to the Agencies; documentation will be in the form of revisions to the ICDF RD/CWP and this RAWP as needed.

All closure activities will be conducted in accordance with the substantive requirements of 40 CFR 264, Subpart G, "Closure and Post-Closure." The following performance standards will be incorporated into all closure activities:

- Minimize the need for further maintenance

- Control, minimize, or eliminate, to the extent necessary, to protect human health and the environment, postclosure escape of hazardous waste, hazardous constituents, leachate, contaminated run-off, or hazardous waste decomposition products to the ground or surface waters or to the atmosphere.

The specific closure discussion that follows separates the ICDF Complex into three distinct facilities: the SSSTF (including the decontamination building and staging areas), the evaporation pond, and the landfill. A general description is provided for each of these facilities regarding how the facility will be closed.

\subsection{Staging, Storage, Sizing, and Treatment Facility Closure}

The SSSTF consists of several different individual components ranging from a decontamination building with a treatment unit to outdoor storage and staging areas, as shown in Figure 1-2. The storage and staging areas have been identified and designated for specific purposes. The ICDF Complex storage and staging areas are described in detail in Section 5 of the O\&M Plan (DOE-ID 2006b). The storage and staging areas that will be closed include the following:

- $\quad$ Staging and Storage Annex (SSA) storage area

- SSA staging area

- Full container staging area

- Bulk soil stockpile staging area

- Tank and container storage area.

The SSA was previously established and designated as a waste storage area in accordance with 40 CFR 262.34(a)(1), "Accumulation Time," which met the requirements of 40 CFR 264, "Standards for Owners and Operators of Hazardous Waste Treatment, Storage, and Disposal Facilities." The SSA included two areas inside the INTEC fence, one asphalt area and a second graded gravel area south of the 
road. Upon finalization of this RAWP, a portion of the SSA designated as the SSA staging area will be closed as a storage area and will operate as a staging area in accordance with 40 CFR 264.554. This document will serve as closure documentation for the southern $150 \mathrm{ft}$ of the SSA area south of the road. The northern $40 \mathrm{ft}$ south of the road, and the entire asphalt paved area north of the road, will remain a storage area.

DOE Idaho has reviewed the weekly inspection reports for the SSA. There have been no spills on the gravel area south of the road. All waste that was stored within the southern $150 \mathrm{ft}$ of the SSA was removed prior to January 21,2003 . Only containerized waste had been previously stored in this area. The maximum volume of waste stored in the southern $150 \mathrm{ft}$ of the SSA, now designated as the SSA staging area, was $6,506 \mathrm{ft}^{3}$. The record review indicates that there were no spills within the designated area to be closed and subsequently used as a staging area. Therefore, there were no residuals to be removed as part of closure of this area. Since all waste containers have been removed from this area, and there were no spills to the environment, the closure of the area is protective of human health and the environment. There is no potential escape of hazardous waste, hazardous constituents, leachate, contaminated run-off, or hazardous waste decomposition products to the ground, surface water, or atmosphere.

It should be noted that this area is designated for further use as a 40 CFR 264.554 staging area for waste. As such, this area will require closure in accordance with 40 CFR 264.554 on or before closure of the ICDF Complex. The remaining portion of the SSA, designated as the SSA storage area, will continue to operate as a storage area in accordance with 40 CFR 262.34(a)(1), meeting the requirements of 40 CFR 264.

The decontamination building is proposed to include a decontamination bay and a treatment area that contains the treatment unit. The decontamination building has been designed and will be operated as a containment building in accordance with 40 CFR 264 Subpart DD. A contaminated equipment pad is located outside the decontamination building. This building will provide the containment for the solids and liquids generated, as well as air handling filters for control of dust.

General facilities consist of the administrative trailer, scale, fencing, pavement, piping, pumps, and other ancillary items.

Prior to the closure of the SSSTF, additional closure information will be provided to the Agencies; documentation will be in the form of revisions to the ICDF RD/CWP and this RAWP as needed. The closure information will identify the steps for closing the various facilities at the SSSTF in accordance with the substantive requirements of 40 CFR 264 Subpart G. Notification of closure will be submitted to EPA and DEQ before the closure activities for the SSSTF begin.

The SSSTF has been designed to operate during the 15-year active life of the landfill, and it is anticipated that waste volume will be reserved in the landfill for the disposal of contaminated materials from the closure of the SSSTF. The following general activities will be performed in closing the SSSTF:

- Site and operations will be assessed for spills or releases as part of the closure activity. If there were no spills or releases, or if those spills/releases were removed, then this information would be documented to support clean closure of the area.

- The decontamination building will be closed by recycling or reusing equipment and materials that are not contaminated or can be decontaminated. Any equipment or materials that cannot be decontaminated will be disposed of on-Site in the ICDF landfill. The building will be demolished and debris will be placed in the ICDF landfill. The decontamination building discharge piping to the 
evaporation pond will be removed and disposed of in the landfill. Following demolition of the building, any contaminated subsoil will be placed in the landfill.

- The contaminated equipment pad will be demolished, and the contaminated debris and subsoil will be placed in the ICDF landfill.

- The SSA storage area may be retained as a storage facility if CERCLA storage is needed after the lifetime of the landfill. However, if the SSA is not needed, it will be clean closed. As necessary, contaminated asphalt concrete area subsoil and fencing will be removed and placed in the ICDF landfill.

- The remaining facilities, including staging areas, administration building, truck scales, and miscellaneous utilities, will be closed following receipt of final waste from the ICDF Complex user sites. Contaminated materials, equipment, or subsoil will be placed in the ICDF landfill.

- Verification sampling will be performed to document the removal of contamination.

Following closure of the SSSTF, as above, the RA Report for the ICDF Complex will be revised to include documentation of closure.

\subsection{Evaporation Pond Closure}

Prior to the closing of the evaporation pond, additional closure information will be provided to the Agencies; documentation will be in the form of revisions to the ICDF RD/CWP and this RAWP as needed. The closure information will identify the steps for closing the evaporation pond and will provide documentation regarding compliance with the substantive requirements of 40 CFR 264 Subpart G, "Closure and Post-Closure"; 40 CFR 264.228, "Closure and Post-Closure Care"; and 40 CFR 264.552(e)(4), "Corrective Action Management Units."

The ICDF evaporation pond has been designated as a RCRA CAMU in the OU 3-13 ROD (DOE-ID 1999), and was designed to accept leachate from the ICDF landfill and aqueous waste generated by ICDF CERCLA activities. The evaporation pond can also accept aqueous waste from WAG 3 CERCLA groundwater activities. In addition, the evaporation pond was designed for a minimum lifetime of 45 years ( 15 years of landfill active life, followed by 30 years of landfill postclosure maintenance). At some point in time following the landfill closure, the evaporation pond will be closed in accordance with the substantive requirements of 40 CFR 264.552, which outlines the closure requirements for CAMUs.

The specific timeframe for the use of the evaporation pond is uncertain, based on the volume of CERCLA liquid waste that will be generated following closure of the landfill. Closure of one evaporation pond cell may occur once leachate generation levels are reduced by the cover system. It is expected that eventually other means of managing leachate will be more effective for small amounts of ICDF Complex CERCLA liquid waste rather than maintaining the evaporation pond. If this is the case, then the pond will be closed and another method of leachate management will be implemented.

The closure of the evaporation pond cells will be conducted in accordance with the substantive requirements of 40 CFR 264 Subpart G, 40 CFR 264.228, and 40 CFR 264.552 (e) (4). The following steps will be taken in closing the evaporation pond cells:

- Remove and dispose of all liquids or solids within the evaporation pond

- Decontaminate or remove and dispose of contaminated containment system components 
- Remove and dispose of contaminated subsoils

- Decontaminate or remove and dispose of pumps, piping, and equipment within the crest pad buildings and between the landfill and the evaporation pond

- Demolish crest pad buildings and dispose of resulting debris

- Grade evaporation pond embankments to provide a smooth area with positive drainage, and blend the area with the surrounding topography.

Contaminated materials, including liquids, solids, containment system components, subsoil, equipment, or building debris, will be disposed of in accordance with CERCLA. Contaminated materials will be mixed waste that, depending on the disposal facilities available at the time, will be disposed of off-Site or on-Site. Building debris and equipment will be recycled, reused, or disposed of at an off-Site or on-Site industrial landfill, provided the material can meet the appropriate disposal requirements. The revisions to the ICDF RD/CWP and this RAWP (as needed) in the future to support closure will include a closure SAP to address closure data needs, including waste characterization and closure confirmation for any areas with known releases. In addition, any sediment removed from the evaporation pond will meet the substantive requirements of 40 CFR 268.48, "Universal Treatment Standards," prior to disposal.

A contingent closure option may be implemented by DOE Idaho depending on the operating history of the evaporation pond, the extent of contaminated containment components, and the available options for disposal of contaminated materials. The contingent closure option will consist of constructing a cap and cover system (similar to that designed for the landfill) for the evaporation pond. As part of the contingent closure option, an evaluation would be performed to determine whether consolidation of contaminated materials would be advantageous. The details of this contingent closure option would be defined as part of the additional closure information submitted to the Agencies prior to closure.

\subsection{Landfill Cap in Place}

The ICDF landfill will be closed through the placement of a final cover system designed to minimize long-term infiltration and protect against inadvertent intrusion for a minimum of 1,000 years. The final cover system has been designed to meet the substantive standards of IDAPA 58.01.05.008, "Standards for Owners and Operators of Hazardous Waste Treatment, Storage, and Disposal Facilities" (40 CFR 264.310[a][1][2] and 40 CFR 264.310[b][1][4][5][6]). Postclosure operations will be conducted in accordance with the substantive standards of IDAPA 58.01.05.008 (40 CFR 264.310[b][1][4][5][6]). Before the final cover system is placed, the landfill will already be covered by an operations layer consisting of clean fill over the waste.

\subsubsection{Final Cover Design}

The cover system has been designed to minimize infiltration and maximize run-off by maintaining a sloped surface, storing water for later release to the atmosphere, providing lateral drainage, and providing a low permeability composite liner barrier system. The cover can be divided by function into three primary layers:

- Upper Layer: The upper water storage component provides water storage during wet periods for later release into the atmosphere during dry periods.

- Middle Layer: The middle section contains a biointrusion layer that provides protection from burrowing animals and a capillary break. 
- Lower Layer: The lower section includes a composite liner system that has a permeability less than or equal to the permeability of the landfill bottom liner and provides for lateral drainage through a high-permeability layer.

The design of the cover system depicting each of the three primary layers is provided in Figure 9-1. A brief discussion of the basic components of the design is provided in the following subsections.

9.3.1.1 Cover Surface and Erosion Protection. The cover surface will consist of a vegetated soil/gravel matrix graded to minimize infiltration and maximize run-off. The surface vegetation will enhance the evapotranspiration properties of the cover and provide erosion control. The soil gravel matrix will prevent excessive soil loss due to wind and surface water run-off. This proposed design is a combination of ICDF site-specific studies and off-Site studies performed at the Hanford facility to support the development of long-term protective covers. The design meets or exceeds the substantive requirements of RCRA Subtitle C design standards specified in IDAPA 58.01.05.008 (40 CFR 264.301, "Design and Operating Regulations," and 40 CFR 264.302, "Action Leakage Rates").

Vegetation will minimize erosion and accelerate removal of water from the water storage layer. Vegetation will consist of local plant species based on vegetation studies performed for disturbed areas at INL (DOE-ID 1989).

The side of the landfill will be sloped at $2.5 \mathrm{H}: 1 \mathrm{~V}(2.5$ horizontal to 1 vertical $)$ as shown on Figure 9-1. The side slopes will be armored with durable basalt rock native to the INL area. The rock armor will be designed to dissipate erosional forces from surface water run-off resulting from extreme probable maximum precipitation events, including flooding events from the Big Lost River. Appropriate testing of designated materials will be conducted, and, if necessary, the rock armor will be oversized to account for long-term degradation.

9.3.1.2 Evapotranspiration Component. The evapotranspiration component of the cover consists of a layer of silty loam-type soils that provide water storage during wet periods for later release to the atmosphere during dry periods. This layer is an integral part of the cover system that provides for the long-term minimization of liquid migration through the closed landfill while functioning with minimal maintenance. The thickness of this layer was determined on the basis of hydrologic modeling provided in EDF-ER-279, "Hydrologic Modeling of Final Cover." The documented sensitivity analysis determined an optimum layer thickness of between 5 and $6.5 \mathrm{ft}$. In the design of the cover, additional thickness was provided for this layer to address erosion control and aeolian effects.

9.3.1.3 Biointrusion/Drainage Component. The primary function of the biointrusion layer is to prevent burrowing animals indigenous to the INL area from penetrating the underlying cover components and waste material. It also provides a high-permeability drainage media should water percolate from the upper portion of the cover system. Past studies at INL, Hanford, and other facilities have shown that a thin layer of gravel is effective in preventing animals and ants from penetrating underlying waste materials (Morris and Bleu 1997; Wing 1993). As shown in Figure 9-1, the cover design includes a layer of Type 3 armor, which is composed of 2- to 5-in. gravel. This material will consist of gravel screened from locally available alluvium at INL. These gravels are composed of granite, quartz, and other durable minerals that are ideally suited for long-term applications. 


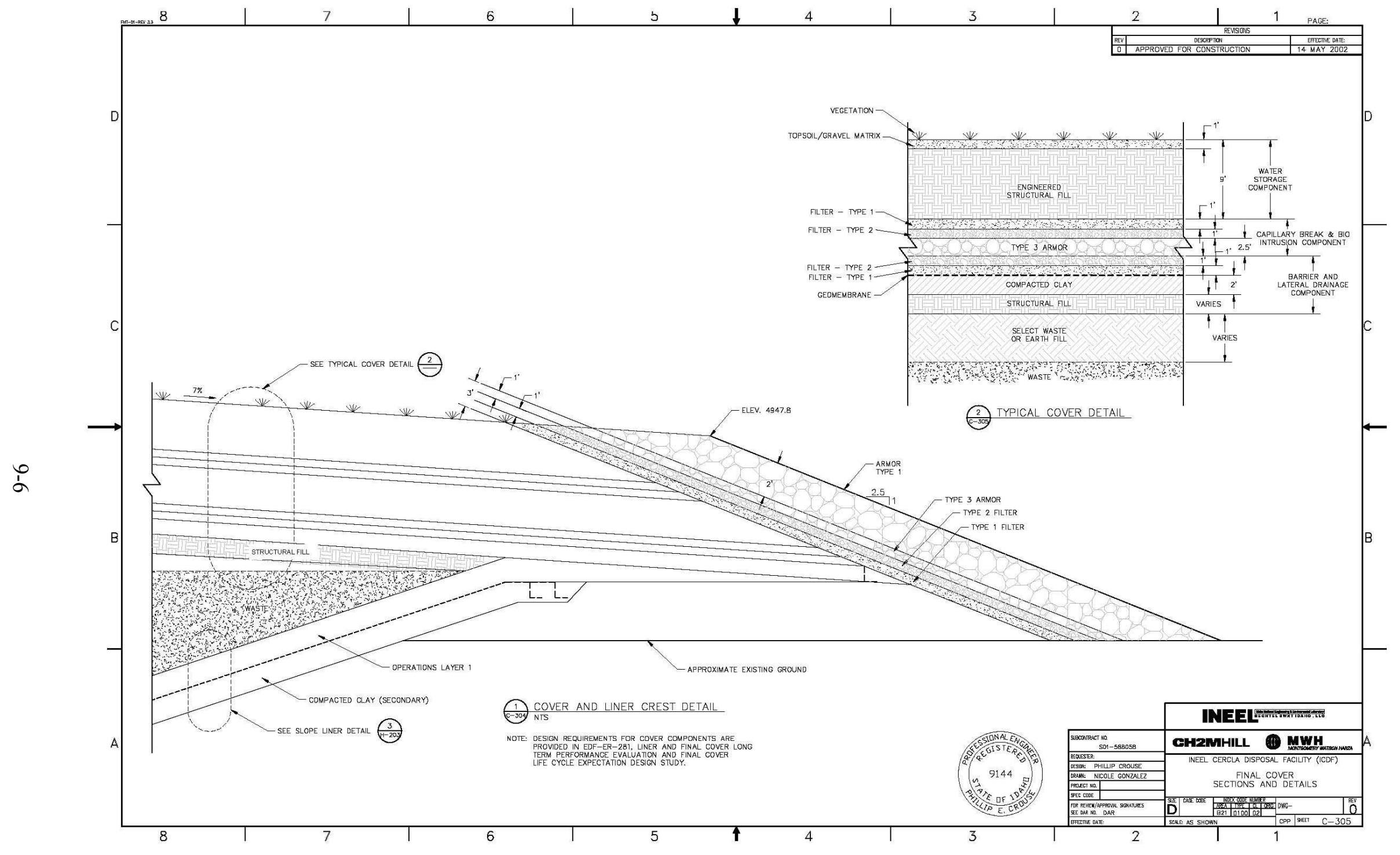

Figure 9-1. ICDF landfill final cover system sections and details. 
9.3.1.4 Barrier Layers. As discussed previously, the primary mechanism for minimizing infiltration through the cover is the upper evapotranspiration layer. Barriers are included in the lower portions of the cover for redundancy and regulatory design criteria. The barrier layers consist of a single HDPE geomembrane/soil bentonite layer composite system. This system is designed to intercept any water penetrating the upper cover sections and divert it laterally through the overlying sand and gravel layers. This barrier layer is designed to comply with the substantive requirements of Subtitle $\mathrm{C}$ hazardous waste closure specified in IDAPA 58.01.05.008 (40 CFR 264.310) and will have a permeability less than or equal to the ICDF bottom liner system.

9.3.1.5 Filter Layers. The cover will be composed of two filter-type materials to prevent fine-grained material from migrating to other components of the cover system. As shown in Figure 9-1, filter layers are included in the cover between the upper storage soil layer and biointrusion layer, between the biointrusion layer and the liner/soil bentonite layer, and beneath the side slope armor. These layers will be composed of graded sands and gravels screened from the alluvium material that exists at INL. The gradation of each filter is designed to prevent fine materials from the overlying layer from migrating downward.

\subsubsection{Closure Information}

Additional closure information will be provided to the Agencies; documentation will be in the form of revisions to the ICDF RD/CWP and this RAWP as needed. The closure information will identify the steps necessary to perform final closure of the landfill facility and will include the following:

- A description of how the landfill will be closed in accordance with the closure performance standards in 40 CFR 264.111, "Closure Performance Standard"

- A description of how final closure will be conducted

- An estimate of the total inventory of hazardous waste disposed of in the landfill

- A detailed description of the steps required to remove or decontaminate all hazardous waste residues on equipment and structures

- A schedule for closure of the landfill

- Results of investigations to identify sources of cover materials and documentation of compliance with cover design modeling assumptions

- Notification of closure for the landfill provided to EPA and DEQ prior to beginning closure activities.

\subsubsection{Closure}

DOE Idaho will notify EPA and DEQ prior to beginning closure activities. Following receipt of the last volume of waste, the closure of the landfill will proceed in the following manner:

- The landfill surface will be graded to conform with minimum slope of $7 \%$ as identified in Appendix Z of the ICDF RD/CWP, Drawing C-304 (DOE-ID 2002).

- The landfill cap will be constructed as shown in cross-section Appendix $\mathrm{Z}$ of the ICDF RD/CWP, Drawing C-305 (DOE-ID 2002). 
- Following closure of the landfill, the RA Report for the ICDF Complex will be revised to include documentation of closure.

- The DOE will survey and record the closed area and preserve that information in federal records.

- The DOE will maintain appropriate institutional controls to prevent activities that may disrupt the containment of the closure measures throughout its ownership of the property. If at any time the title or possession to any portion of the affected property is being transferred out of federal ownership and control, DOE will ensure that the appropriate institutional controls available at the time (which may include land use restrictions by local ordinance, state law, or through restrictive covenants or other means) are instituted no later than the time of such transfer. Transfers of federal real property will be conducted in compliance with all requirements of 42 USC $\S 9620$ (CERCLA $\S 120[\mathrm{~h}]$ ) with regard to such transfers, including the giving of notifications and warranties to transferees.

\subsubsection{Post-Closure Maintenance}

Detailed postclosure information will be submitted to EPA and DEQ in the form of revisions to the ICDF RD/CWP and this RAWP as needed in accordance with the FFA/CO (DOE-ID 1991). The postclosure information will identify the activities that will be conducted after closure of the landfill and the frequency of these activities. The postclosure information will include at least the following items:

- A description of the planned monitoring activities and frequencies at which they will be performed. The applicable sections of the Groundwater Monitoring Plan (DOE-ID 2004) will be summarized as they apply to postclosure activities.

- A description of the planned maintenance activities and frequencies at which they will be performed to ensure the integrity of the cap and final cover system and the function of the monitoring equipment.

- The name, address, and phone number of the person or office to contact during the postclosure period.

Postclosure activities generally will consist of monitoring and reporting in accordance with the substantive requirements of 40 CFR 264.310. Maintenance and monitoring of waste containment systems also will be conducted in accordance with the substantive requirements of 40 CFR 264.310. Following the completion of postclosure activities, written notification will be provided to EPA and DEQ.

The key component of the landfill closure will be the engineered cap. The performance of the cap will be monitored during the postclosure period, based on leachate recovered from the leachate collection and recovery system. When long-term, steady-state conditions are achieved, the annual totals will be compared with the cap modeling totals to evaluate the infiltration through the cap system. Following the postclosure period, the cap will be evaluated, based on the condition of the upper store/release zones of the cap. If the upper portions of the cap system remain in place, the remainder of the cap also will be effective in minimizing infiltration. The thickness of the cap will be surveyed periodically to ensure the cap thickness recommended in the RD/CWP is maintained (DOE-ID 2002).

\subsubsection{Institutional Controls}

The ICDF landfill closure requirements will include access restrictions with a buffer zone that will be maintained around the landfill for as long as the landfill contents remain a threat to human health and the environment. Institutional controls are designed to prevent disturbance of closed areas and to maintain a cumulative carcinogenic risk of less than $1 \times 10^{-4}$ and a total hazard index of 1 . 
DOE Idaho is required to monitor the ICDF Complex after its operational life is completed. Institutional controls for this facility will include proper signage, security, and monitoring. The long-term management of the ICDF Complex and associated monitoring, maintenance, etc., will be transferred to the INL Long-Term Stewardship Program. DOE Idaho will place easily visible permanent markers at all the corner boundaries for each cell of the landfill and identify the potential hazards. In addition, DOE Idaho will maintain all institutional controls until that responsibility is passed, along with management of the property, to another federal agency such as the Bureau of Land Management.

DOE Idaho will further ensure that the final cover is designed to serve as an intrusion barrier for 1,000 years (EDF-ER-281). If ownership of any portion of the land is ever proposed for transfer outside the federal government, DOE Idaho will fulfill the requirements of 42 USC $\S 9620$ (CERCLA §120[h]) to provide the transferee with complete notification and warranty of completed RA. At such time, the federal government will establish, in cooperation with local governments, appropriate land use restrictions, zoning restrictions, and deed restrictions on the ICDF landfill and its adjacent buffer zone, which will preclude industrial, institutional, or residential development until unacceptable risk no longer exists. These documents will include disposal records and the marker locations. These conditions will be verified as part of the 5-year review.

\subsection{Closure Documentation/Certification}

The closure documentation will be completed in two separate closure activities: (1) the SSSTF with the ICDF landfill and (2) the ICDF evaporation pond. These facilities will have separate closure documentation, as each facility has a different timeframe for closure. To document closure, the RA Report for the ICDF Complex will be revised in accordance with the FFA/CO (DOE-ID 1991). 
9-10 


\section{PROJECT SCHEDULE AND COST ESTIMATE}

A project schedule for operations and maintenance of the ICDF Complex, included as Appendix N, has been developed as part of this RAWP. The schedule presented in Appendix N presents the project working schedule for ICDF Complex operations through calendar year 2012. The accelerated project working schedule (rather than the planned 15-year operations period) is presented to be consistent with current DOE Idaho initiatives and the cost estimate presented in EDF-2385, "INEEL CERCLA Disposal Facility Complex On-Site Versus Off-Site Cost Comparison."

The schedule includes activities that will occur during ICDF Complex operations. Table 10-1 presents a summary of project schedule key dates. An enforceable milestone is established in Table 10-1 for the submittal of the draft ICDF Complex RA Report, which is a primary document under the FFA/CO (DOE-ID 1991).

Table 10-1. Key dates of the project working schedule.

Date

August 19, 2002

(Enforceable date

December 9, 2002)

January-June 2003

February 28, 2003

May 2003

September 2-4, 2003

September 10, 2003

September 13, 2003

July 29, 2003

September 14, 2005

September 2005

December 1, 2005

(Enforceable milestone)
Scheduled Item

Submit draft ICDF Complex RAWP to EPA and DEQ for review

Public workshop

Submit revision to the SSSTF RD/CWP for treatment unit design (Note: This document has since been cancelled. Users reference ICDF RD/CWP.)

Perched water Agency discussion regarding the appropriateness of adding perched water to the detection monitoring network (DOE-ID 2003a)

Conduct ICDF Complex prefinal inspection

Submit ICDF Complex Prefinal Inspection Report

Begin ICDF Complex operations

Submit revision to the ICDF RAWP for treatment unit operations

Conduct ICDF treatment facilities prefinal inspection

Submit ICDF treatment facilities Prefinal Inspection Report

Submit draft ICDF Complex RA Report (primary document)

Submit revisions to ICDF RD/CWP, and ICDF Complex RAWP as needed.

Several assumptions are key to the ICDF Complex operations proceeding in accordance with the project schedule presented in Appendix N. Section N-1 outlines these assumptions, which are the basis for the schedule presented in Figure N-1 of Appendix N.

The cost estimate for on-Site treatment and disposal has been extensively evaluated in EDF-2385, "INEEL CERCLA Disposal Facility Complex On-Site Versus Off-Site Cost Comparison." This estimate, which includes design, construction, startup, operations and maintenance, and closure and postclosure costs, is $\$ 87$ million in FY 2002 dollars. Further details of the cost estimate, as well as a comparison with current off-Site treatment and disposal costs, is provided in EDF-2385. 
10-2 


\section{COMMUNITY INVOLVEMENT}

Idaho National Laboratory has an ongoing commitment to maintain a community dialogue during the RD/RA phase of all CERCLA projects, as outlined in the Community Relations Plan: A Guide to Public Involvement in the Environmental Restoration Program at the INEL (INEL 1995). In the OU 3-13 ROD (DOE-ID 1999), the Agencies also made a commitment to keep the community informed of the content and progress of the RD phase through a series of fact sheets. Additionally, the Agencies committed to a variety of presentations and discussions with the INL Citizens Advisory Board (CAB) and/or focus groups during the development of the design and construction of the ICDF Complex. The Agencies further committed to being available to discuss various ICDF Complex RD/RA activities with interested public groups as appropriate.

There has been considerable public interest in the ICDF Complex project. Since the signature of the OU 3-13 ROD, and throughout the RD phase of the project, DOE Idaho has distributed fact sheets, conducted public workshops, developed presentations, and held discussions with the INL CAB. DOE Idaho representatives have met with interested citizens and posted project information on the INL external web site (www.inel.gov).

In July 2001, the Agencies held a public workshop in Idaho Falls, Idaho, to offer information on the 30\% design components of the ICDF Complex. In November 2001, the Agencies held a workshop on the $60 \%$ design. These workshops were advertised in local and regional newspapers. Technical and management representatives were present at both workshops to answer questions from the public. To augment the workshop information, DOE Idaho also mailed three ICDF Complex fact sheets (at the 30, 60 , and $90 \%$ design phases) to all interested citizens on the INL mailing list. Posters from the workshops and the fact sheets were posted to the INL external web page. Copies of the documents were also placed in information repositories and made available upon request. A workshop to discuss how the ICDF Complex will be managed and operated will be held after development of this RAWP and prior to the start of operations. In addition, INL maintains a toll free hotline (1-800-708-2680) to take calls from citizens interested in the ICDF Complex project.

During the RA phase of this project, the Agencies are similarly committed to maintaining their dialogue with the community. DOE Idaho has made a commitment to the public to provide more opportunities for public involvement than the minimum required by law, which requires only the placement of the ICDF Complex RAWP and ICDF Complex RA Report in the INL Information Repository. Although not required to do so by law, INL is committed to distributing fact sheets and articles about the project and informing the media of the degree of success at completion of the RA. DOE Idaho is also committed to the following activities, upon public request:

- Scheduling site tours, briefings, or discussion groups

- Preparing an exhibit to explain RA when appropriate

- Distributing a "question and answer" fact sheet concerning issues of interest to citizens.

Examples of other informational events that may be sponsored by DOE Idaho or the Agencies include conducting public workshops, issuing press releases, continuing to support the toll-free phone hotline, and briefing local officials, the INL CAB, and interested citizens. 
Idaho National Laboratory is committed to providing tours of the ICDF Complex upon request whenever possible. Interested stakeholders may contact the INL tour office at 1-208-526-0050 or call the toll-free public information hotline at 1-800-708-2680 to request information on speakers, briefings, documents, or opportunities for public information and community dialogue. (Non-U.S. citizens will need to contact the tours office no less than 6 weeks in advance of the intended visit.) Information regarding visitor access requirements is provided in the HASP (INL 2006) in Appendix F of this RAWP. Comments and complaints should be addressed to the Idaho Cleanup Project at MS 2501, P.O. Box 1625, Idaho Falls, ID 83415-2501. 


\section{REFERENCES}

29 CFR 1910.120, 1998, "Hazardous Waste Operations and Emergency Response," Code of Federal Regulations, Office of the Federal Register, July 1998.

40 CFR 122.26, 1999, "Storm Water Discharges," Code of Federal Regulations, Office of the Federal Register, July 1999.

40 CFR 262.34, 1999, “Accumulation Time," Code of Federal Regulations, Office of the Federal Register, July 1999.

40 CFR 264, 1999, "Standards for Owners and Operators of Hazardous Waste Treatment, Storage, and Disposal Facilities," Code of Federal Regulations, Office of the Federal Register, July 1999.

40 CFR 264.15, 1999, "General Inspection Requirements," Code of Federal Regulations, Office of the Federal Register, July 1999.

40 CFR 264.97, 2000, "General Ground-water Monitoring Requirements," Code of Federal Regulations, Office of the Federal Register, July 2000.

40 CFR 264.111, 1999, "Closure Performance Standard," Code of Federal Regulations, Office of the Federal Register, July 1999.

40 CFR 264.173, 1999, "Management of Containers," Code of Federal Regulations, Office of the Federal Register, July 1999.

40 CFR 264.195, 1999, "Inspections," Code of Federal Regulations, Office of the Federal Register, July 1999.

40 CFR 264.226, 1999, "Monitoring and Inspection," Code of Federal Regulations, Office of the Federal Register, July 1999.

40 CFR 264.228, 1999, "Closure and Post-Closure Care," Code of Federal Regulations, Office of the Federal Register, July 1999.

40 CFR 264.301, 1992, "Design and Operating Requirements," Code of Federal Regulations, Office of the Federal Register, January 1992.

40 CFR 264.302, 1992, “Action Leakage Rates," Code of Federal Regulations, Office of the Federal Register, January 1992.

40 CFR 264.303, "Monitoring and Inspection," Code of Federal Regulations, Office of the Federal Register, July 1999.

40 CFR 264.310, 1986, "Closure and Post-Closure Care," Code of Federal Regulations, Office of the Federal Register, May 1986.

40 CFR 264.552, 1998, "Corrective Action Management Units (CAMU)," Code of Federal Regulations, Office of the Federal Register, November 1998.

40 CFR 264.554, 1999, "Staging Piles," Code of Federal Regulations, Office of the Federal Register, July 1999. 
40 CFR 264.1101, 1999, "Design and Operating Standards," Code of Federal Regulations, Office of the Federal Register, July 1999.

40 CFR 264, Subpart F, 1999, "Releases from Solid Waste Management Units," Code of Federal Regulations, Office of the Federal Register, July 1999.

40 CFR 264, Subpart G, 1986, "Closure and Post-Closure," Code of Federal Regulations, Office of the Federal Register, May 1986.

40 CFR 264 Subpart DD, 1999, “Containment Buildings," Code of Federal Regulations, Office of the Federal Register, July 1999.

40 CFR 268.45, 1999, “Treatment Standards for Hazardous Debris,” Code of Federal Regulations, Office of the Federal Register, July 1999.

40 CFR 268.48, 1999, "Universal Treatment Standards," Code of Federal Regulations, Office of the Federal Register, July 1999.

40 CFR 268.49, 1998, “Alternative LDR Treatment Standards for Contaminated Soil,” Code of Federal Regulations, Office of the Federal Register, July 1998.

40 CFR 300, 1994, "National Oil and Hazardous Substance Pollution Contingency Plan," Code of Federal Regulations, Office of the Federal Register, September 1994.

15 USC § 2601 et seq., 1976, “Toxic Substances Control Act,” United States Code.

42 USC $§ 6921$ et seq., 1976, Subtitle C, "Hazardous Waste Management," Resource Conservation and Recovery Act of 1976, United States Code (as amended).

42 USC § 9620 (CERCLA §120) 1986, "Comprehensive Environmental Response, Compensation and Liability Act of 1980," United States Code (as amended).

DOE-ID, 1989, Guidelines for Revegetation of Disturbed Sites at the Idaho National Engineering Laboratory, DOE/ID-12114, U.S. Department of Energy Idaho Operations Office, June 1989.

DOE-ID, 1991, Federal Facility Agreement and Consent Order for the Idaho National Engineering Laboratory, Administrative Docket No. 1088-06-29-120, U.S. Department of Energy Idaho Operations Office; U.S. Environmental Protection Agency, Region 10; Idaho Department of Health and Welfare, December 1991.

DOE-ID, 1994, Remedial Design and Remedial Action Guidance for the Idaho National Engineering Laboratory, DOE/ID-12584-152, GJPO-ESO-12, Rev. 2, U.S. Department of Energy Idaho Operations Office, September 1994.

DOE-ID, 1997a, Comprehensive RI/FS for the Idaho Chemical Processing Plant OU 3-13 at the INEELPart A, RI/BRA Report (Final), DOE/ID-10534, Rev. 0, U.S. Department of Energy Idaho Operations Office, November 1997.

DOE-ID, 1997b, Comprehensive RI/FS for the Idaho Chemical Processing Plant OU 3-13 at the INEEL_Part B, FS Report (Final), DOE/ID-10572, U.S. Department of Energy Idaho Operations Office, November 1997. 
DOE-ID, 1998, Comprehensive RI/FS for the Idaho Chemical Processing Plant OU 3-13 at the INEELPart B, FS Supplement Report, DOE/ID-10619, Rev. 2, U.S. Department of Energy Idaho Operations Office, October 1998.

DOE-ID, 1999, Final Record of Decision, Idaho Nuclear Technology and Engineering Center, Operable Unit 3-13, DOE/ID-10660, Rev. 0, U.S. Department of Energy Idaho Operations Office, U.S. Environmental Protection Agency Region 10, and State of Idaho Department of Health and Welfare, October 1999.

DOE-ID, 2000, Remedial Design/Remedial Action Scope of Work for Waste Area Group 3, Operable Unit 3-13, DOE/ID-10721, Rev. 1, U.S. Department of Energy Idaho Operations Office, February 2000.

DOE-ID, 2002, INEEL CERCLA Disposal Facility Remedial Design/Construction Work Plan, DOE/ID-10848, Rev. 1, U.S. Department of Energy Idaho Operations Office, May 2002.

DOE-ID, 2003a, INEEL CERCLA Disposal Facility Groundwater Detection Monitoring Program: Data Analysis Plan, DOE/ID-10998, Rev. 0, U.S. Department of Energy Idaho Operations Office, February 2003.

DOE-ID, 2003b, Treatability Study Test Plan for Soil Stabilization, DOE/ID-10903, Rev. 0, U.S. Department of Energy Idaho Operations Office, February 2003.

DOE-ID, 2003c, Sampling and Analysis Plan for SSSTF Waste Stabilization Operations, DOE/ID-10924, Rev. 0, U.S. Department of Energy Idaho Operations Office, February 2003.

DOE-ID, 2003d, ICDF Complex Operational and Monitoring Sampling and Analysis Plan, DOE/ID-11005, Rev. 0, U.S. Department of Energy Idaho Operations Office, February 2003.

DOE-ID, 2004, ICDF Complex Groundwater Monitoring Plan, DOE/ID-10955, Rev. 3, U.S. Department of Energy Idaho Operations Office, March 2004.

DOE-ID, 2005, ICDF Complex Waste Profile and Verification Sample Guidance, DOE/NE-ID-11175, Rev. 1, U.S. Department of Energy Idaho Operations Office, February 2005.

DOE-ID, 2006a, ICDF Complex Waste Acceptance Criteria, DOE/ID-10881, Rev. 3, U.S. Department of Energy Idaho Operations Office, October 2006.

DOE-ID, 2006b, ICDF Complex Operations and Maintenance Plan, DOE/ID-11000, Rev. 2, U.S. Department of Energy Idaho Operations Office, February 2006.

DOE-ID, 2006c, ICDF Complex Operations Waste Management Plan, DOE/ID-10886, Rev. 1, U.S. Department of Energy Idaho Operations Office, December 2006.

DOE O 435.1, Change 1, 2001, "Radioactive Waste Management,” U.S. Department of Energy, August 28, 2001.

EDF-1730, 2002, "Staging, Storage, Sizing, and Treatment Facility (SSSTF) Debris Treatment Process Selection and Design," Rev. 0, Idaho National Engineering and Environmental Laboratory, March 2002. 
EDF-2236, 2003, "NESHAP Compliance Demonstration for the ICDF Complex," Rev. 0, Idaho National Engineering and Environmental Laboratory, February 2003.

EDF-2237, 2003, "IDAPA Air Compliance Demonstration for the ICDF Complex," Rev. 0, Idaho National Engineering and Environmental Laboratory, February 2003.

EDF-2385, 2003, “INEEL CERCLA Disposal Facility Complex On-Site Versus Off-Site Cost Comparison," Rev. 0, Idaho National Engineering and Environmental Laboratory, February 2003.

EDF-2648, 2002, “SSSTF Process Systems Drain Pipe Sizing,” Rev. 0, Idaho National Engineering and Environmental Laboratory, March 2002.

EDF-ER-271, 2002, "Evaporation Pond Sizing with Water Balance and Make-up Water Calculations," Rev. 1, Idaho National Engineering and Environmental Laboratory, May 2002.

EDF-ER-279, 2002, “Hydrologic Modeling of Final Cover," Rev. 2, Idaho National Engineering and Environmental Laboratory, May 2002.

EDF-ER-281, 2006, "Liner and Final Cover Long-Term Performance Evaluation and Final Cover Life Cycle Expectation,” Rev. 2, Idaho National Laboratory, August 2006.

EDF-ER-286, 2005, “ICDF Waste Placement Plan,” Rev. 4, Idaho Cleanup Project, July 2005.

EDF-ER-327, 2005, “INEEL CERCLA Disposal Facility Short-Term Risk Assessment” Rev. 2, Idaho National Engineering and Environmental Laboratory, January 2005.

EPA, 2001, “Comprehensive Five-Year Review Guidance,” EPA 540-R-01-007, U.S.Environmental Protection Agency, June 2001.

Executive Order 12580, “Superfund Implementation,” January 29, 1987.

Form 435.95, 2006, “ICDF Waste Tracking,” Idaho Completion Project, Idaho National Laboratory.

HWMA, 1983, "Hazardous Waste Management Act of 1983," Idaho Code Sections 39-4401 et seq., 1983.

IDAPA, 58.01.05.008, 2000, "Standards for Owners and Operators of Hazardous Waste Treatment, Storage, and Disposal Facilities," Idaho Administrative Procedures Act, Idaho Department of Environmental Quality, April 2000 (as promulgated as of December 1999).

INEL, 1995, Community Relations Plan: A Guide to Public Involvement in the Environmental Restoration Program at the INEL, Idaho National Engineering Laboratory, May 1995.

INL, 2006, Health and Safety Plan for Idaho CERCLA Disposal Facility Operations, INEEL/EXT-01-01318, Rev. 3, Idaho Cleanup Project, Idaho National Laboratory, August 2006.

Morris R. C. and Bleu R. D., 1997, “Annual Technical Report Calendar 1996,” Environmental Science and Research Foundation Report Series, Number 17, Idaho National Engineering and Environmental Laboratory.

PLN-114, 2005, “INEEL Emergency Plan RCRA Contingency Plan,” Rev. 24, Emergency Preparedness Department, Idaho National Laboratory, September 2005. 
PLN-914, 2006, "Waste Tracking Plan for the Idaho CERCLA Disposal Facility Complex," Rev. 1, Idaho National Engineering and Environmental Laboratory, March 2006.

PLN-962, 2002, "Storm Water Pollution Prevention Plan for the ICDF Landfill and Evaporation Pond," Rev. 0, Idaho National Engineering and Environmental Laboratory, May 2002.

PLN-1034, 2002, "Storm Water Pollution Prevention Plan for Construction Activities - Staging, Storage, Sizing, and Treatment Facility Phase I (Draft)," Idaho National Engineering and Environmental Laboratory, March 2002.

TFR-17, 2002, “WAG 3 Staging, Storage, Sizing, and Treatment Facility,” Rev. 2, Idaho National Engineering and Environmental Laboratory, March 2002.

TFR-71, 2004, "INEEL CERCLA Disposal Facility and Evaporation Pond," Rev. 3, Idaho National Engineering and Environmental Laboratory, August 2004.

Wing, N. R., 1993, “Permanent Isolation Surface Barrier: Functional Performance,” Westinghouse Hanford Company, Richland, WA. 


\section{Appendix Volume 1 of 2-Idaho CERCLA Disposal Facility Complex Operations and Maintenance}





\section{Appendix A}

ICDF Complex Operations and Maintenance Plan (DOE/ID-11000) 
A-2 
Appendix Volume 2 of 2-Operational Information and Project Management 



\section{Appendix B}

ICDF Complex Waste Profile and Verification Sample Guidance (DOE/NE-ID-11175) 
B-2 


\section{Appendix C}

\section{Waste Tracking Plan for the Idaho CERCLA Disposal Facility Complex (PLN-914)}




$$
\text { C-2 }
$$




\section{Appendix D}

(ICDF Complex Waste Verification Sampling and Analysis Plan [DOE/ID-10985])

This document has been replaced by the document now contained in Appendix B. 
D-2 
Appendix E

INEEL CERCLA Disposal Facility Short-Term Risk Assessment

(EDF-ER-327) 
E-2 


\section{Appendix F \\ Health and Safety Plan for Idaho CERCLA Disposal Facility Operations (INEEL/EXT-01-01318)}


F-2 
Appendix G

ICDF Complex Operations Waste Management Plan

(DOE/ID-10886) 
G-2 


\section{Appendix H}

INEEL CERCLA Disposal Facility Groundwater Detection Monitoring Program: Data Analysis Plan (DOE/ID-10998) 
H-2 


\section{Appendix I}

\section{Treatability Study Test Plan for Soil Stabilization (DOE/ID-10903)}




\section{Appendix J}

\section{Sampling and Analysis Plan for SSSTF Waste Stabilization Operations, WAG 3, OU 3-13 (DOE/ID-10924)}




\section{Appendix K}

\section{NESHAP Compliance Demonstration for the ICDF Complex (EDF-2236)}


K-2 


\section{Appendix L}

IDAPA Air Compliance Demonstration for the ICDF Complex (EDF-2237) 


$$
\text { L-2 }
$$




\section{Appendix M}

\section{ICDF Complex Operational and Monitoring Sampling and Analysis Plan (DOE/ID-11005)}


M-2 


\section{Appendix N}

\section{Project Schedule and Assumptions}


N-2 


\section{Appendix 0}

\section{INEEL CERCLA Disposal Facility Complex On-Site Versus Off-Site Cost Comparison (EDF-2385)}


O-2 


\section{Appendix P}

\section{Responses to Comments}


P-2 